\title{
GEOMORFOLOGI DAN HIDROLOGI KARST
}

BAHAN AJAR

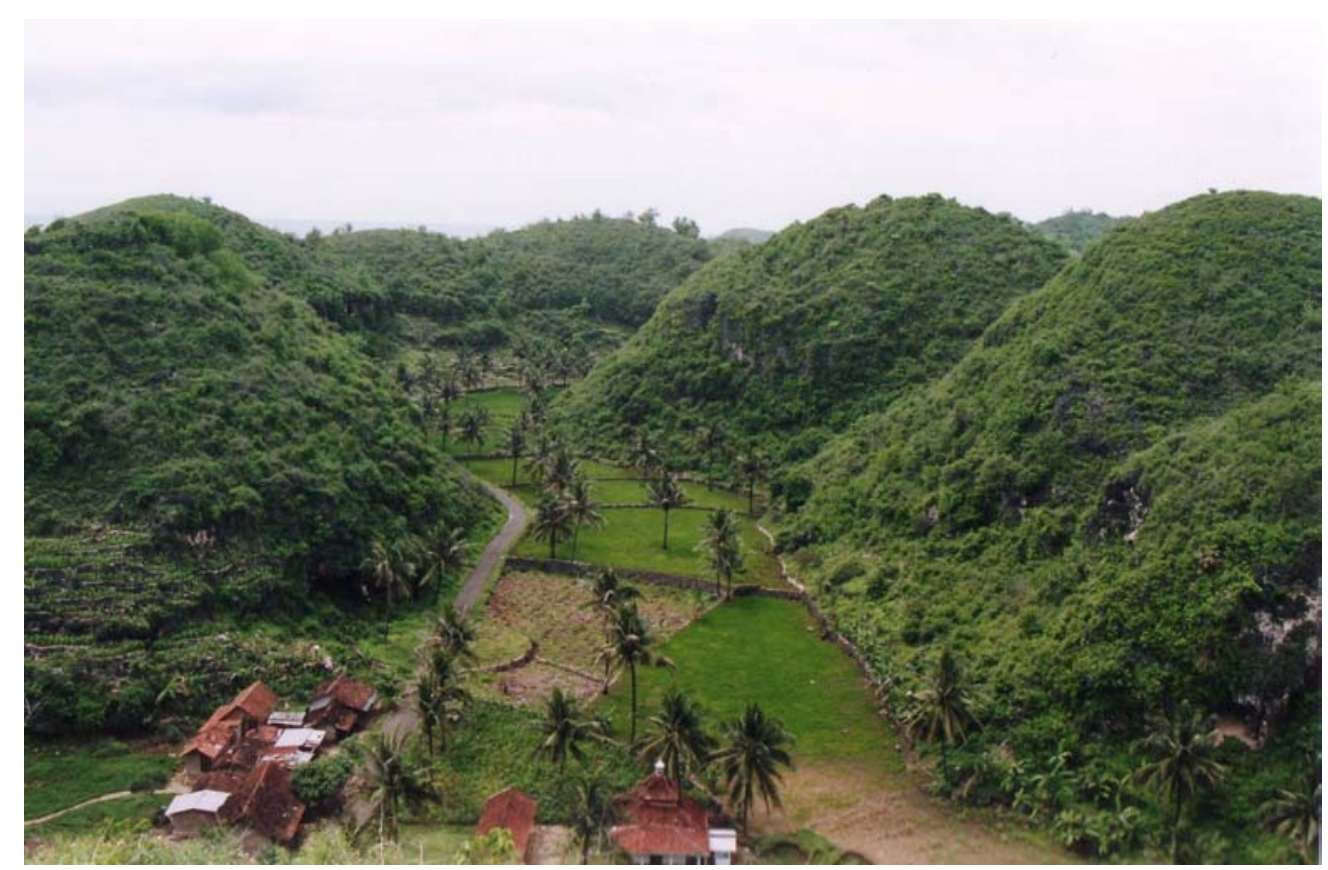

OLEH:

Eko Haryono

Tjahyo Nugroho Adji

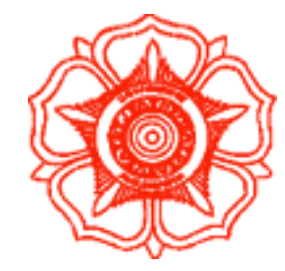

KELOMPOK STUDI KARST

FAKULTAS GEOGRAFI

UNIVERSITAS GADJAH MADA 


\section{DAFTAR ISI}

HALAMAN JUDUL

BAGIAN 1. GEOMORFOLOGI KARST

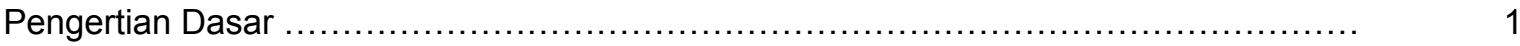

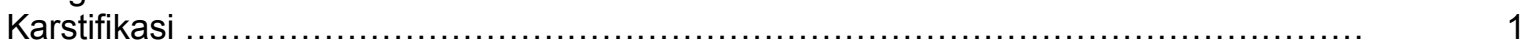

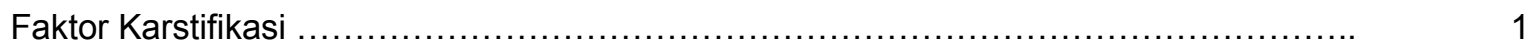

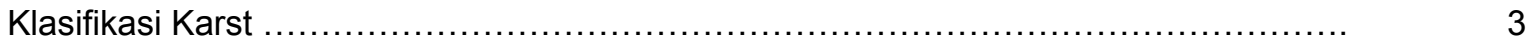

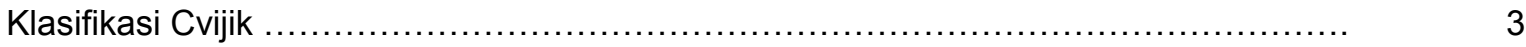

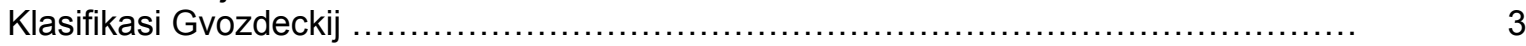

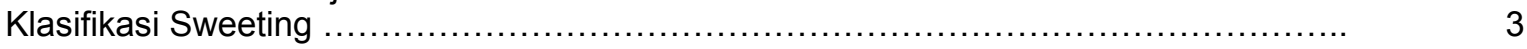

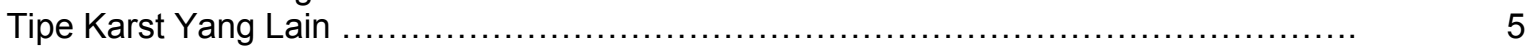

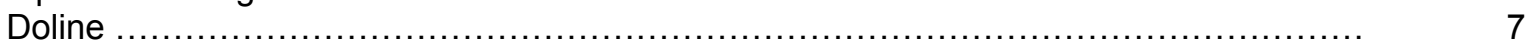

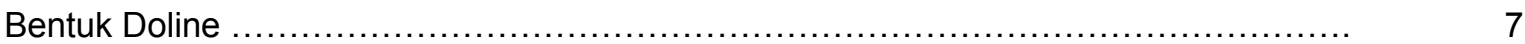

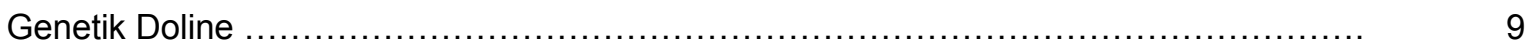

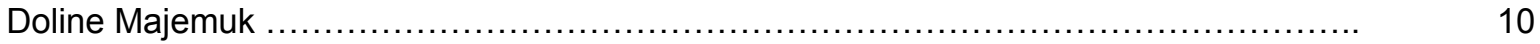

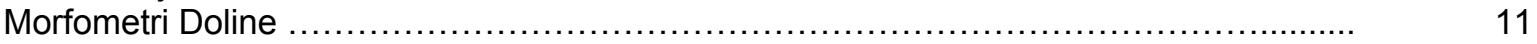

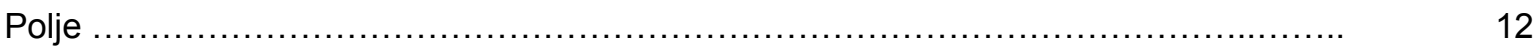

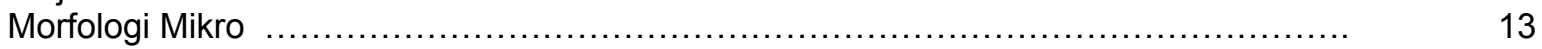

BAGIAN 2. HIDROLOGI KARST

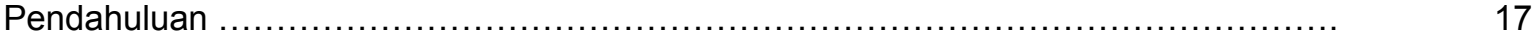

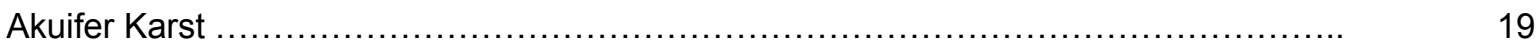

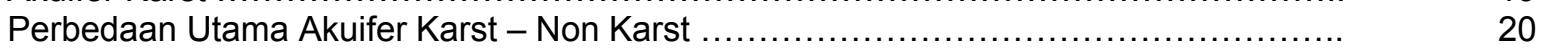

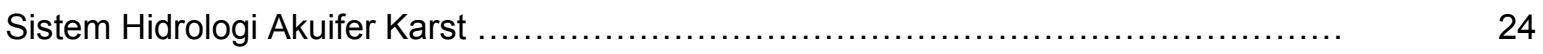

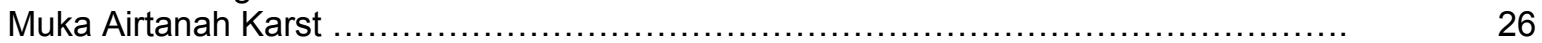

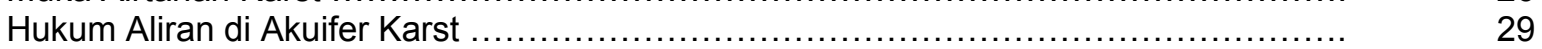

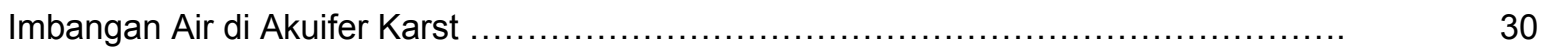

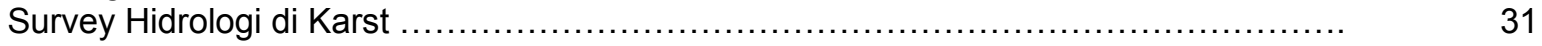

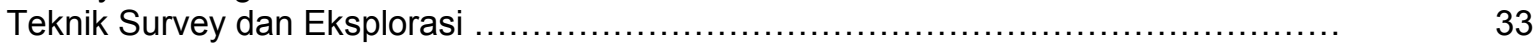

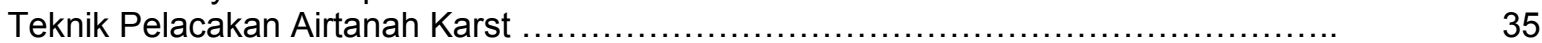

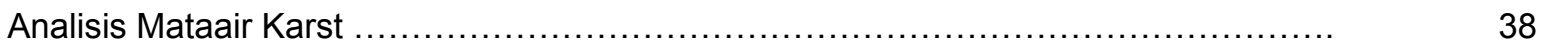

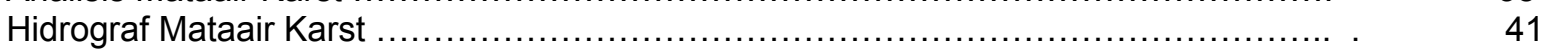

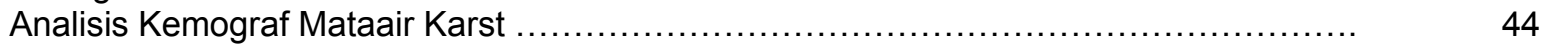




\section{PENGERTIAN DASAR}

Karst merupakan istilah dalam bahasa Jerman yang diturunkan dari bahasa Slovenia (kras) yang berarti lahan gersang berbatu. Istilah ini di negara asalnya sebenarnya tidak berkaitan dengan batugamping dan proses pelarutan, namun saat ini istilah kras telah diadopsi untuk istilah bentuklahan hasil proses perlarutan. Ford dan Williams (1989) mendefini-sikan karst sebagai medan dengan kondisi hidrologi yang khas sebagai akibat dari batuan yang mudah larut dan mempunyai porositas sekunder yang berkembang baik.

Karst dicirikan oleh:

1. terdapatnya cekungan tertutup dan atau lembah kering dalam berbagai ukuran dan bentuk,

2. langkanya atau tidak terdapatnya drainase/ sungai permukaan, dan

3. terdapatnya goa dari sistem drainase bawah tanah.

Karst tidak hanya terjadi di daerah berbatuan karbonat, tetapi terjadi juga di batuan lain yang mudah larut dan mempunyai porositas sekunder (kekar dan sesar intensif), seperti batuan gipsum dan batugaram. Namun demikian, karena batuan karbonat mempunyai sebaran yang paling luas, karst yang banyak dijumpai adalah karst yang berkembang di batuan karbonat. Oleh karenanya bahsan buku ini selanjutnya hanya akan menguraikan karst batuan karbonat.

\section{KARSTIFIKASI}

Karstifikasi atau proses permbentukan bentuk-lahan karst didominasi oleh proses pelarutan. Proses pelaturan batugamping diawali oleh larutnya $\mathrm{CO}_{2}$ di dalam air membentuk $\mathrm{H}_{2} \mathrm{CO}_{3}$. Larutan $\mathrm{H}_{2} \mathrm{CO}_{3}$ tidak stabil terurai menjadi $\mathrm{H}^{-}$dan $\mathrm{HCO}_{3}{ }^{2-}$. Ion $\mathrm{H}^{-}$inilah yang selanjutnya menguraikan $\mathrm{CaCO}_{3}$ menjadi $\mathrm{Ca}^{2+}$ dan $\mathrm{HCO}_{3}{ }^{2-}$ (Gambar 1.1.).

Secara ringkas proses pelarutan dirumuskan dengan reaksi sebagai berikut.

$$
\mathrm{CaCO}_{3}+\mathrm{H}_{2} \mathrm{O}+\mathrm{CO}_{2} \longrightarrow \mathrm{Ca}^{2+}+2 \mathrm{HCO}^{3-}
$$

\section{FAKTOR KARSTIFIKASI}

Karstifikasi dipengaruhi oleh dua kelompok faktor, faktor pengontrol dan faktor pendorong. Faktor pengontrol menentukan dapat tidaknya proses karstifikasi berlangsung, sendangkan faktor pendorong menentukan kecepatan dan kesempurnaan proses karstifikasi.

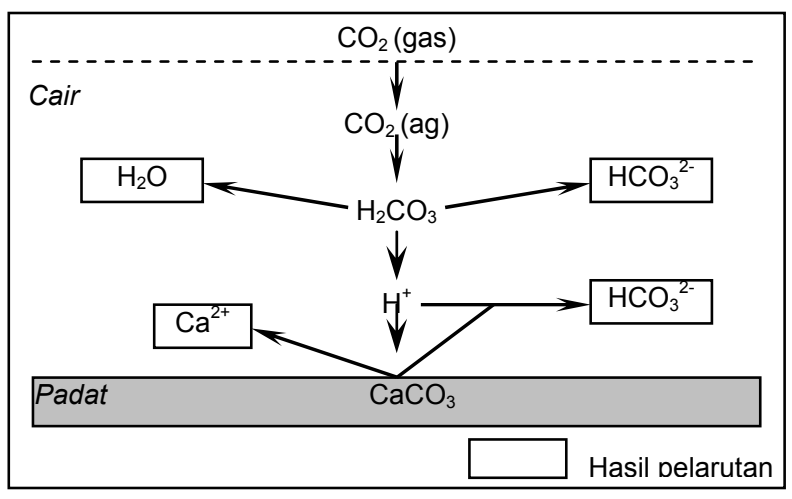

Gambar 1.1.

Skema proses pelarutan batugamping (Trudgil, 1985)

\section{Faktor Pengontrol}

1. Batuan mudah larut, kompak, tebal, dan mempunyai banyak rekahan

2. Curah hujan yang cukup (>250 $\mathrm{mm} /$ tahun)

3. Batuan terekspos di ketinggian yang memungkinkan perkembangan sirkulasi air/drainase secara vertikal.

\section{Faktor pendorong}

1. Temperatur

2. Penutupan hutan

Batuan yang mengandung $\mathrm{CaCO}_{3}$ tinggi akan mudah larut. Semakin tinggi kandungan $\mathrm{CaCO}_{3}$, semakin berkembang bentuklahan karst. Kekom-pakan batuan menentukan kestabilan morfologi karst setelah mengalami pelarutan. Apabila batuan lunak, maka setiap kenampakan karst yang terbentuk seperti karen dan bukit akan cepat hilang karena proses pelarutan itu sendiri maupun proses erosi dan gerak masa batuan, sehingga kenampakan karst tidak dapat berkembang baik. Ketebalan menentukan terbentuknya sikulasi air secara vertikal lebih. Tanpa adanya lapisan yang tebal, sirkulasi air secara vertikal yang merupakan syarat karstifikasi dapat berlangsung. Tanpa adanya sirkulasi vertikal, proses yang terjadi adalah aliran lateral seperti pada sungai-sungai permukaan dan cekungan-cekungan tertutup tidak dapat terbentuk. Rekahan batuan merupakan jalan masuknya air membentuk drainase vertikal dan berkembangnya sungai bawah tanah serta pelarutan yang terkonsentrasi. 
Curah hujan merupakan media pelarut utama dalam proses karstifikasi. Semakin besar curah hujan, semakin besar media pelarut, sehingga tingkat pelarutan yang terjadi di batuan karbonat juga semakin besar. Ketinggian batugamping terekspos di permukaan menentukan sirikulasi/drainase secara vertikal.

Walupun batugamping mempunyai lapisan tebal tetapi hanya terekspos beberapa meter di atas muka laut, karstifikasi tidak akan terjadi. Drainase vertikal akan terjadi apabila julat/jarak antara permukaan batugamping dengan muka air tanah atau batuan dasar dari batugamping semakin besar. Semakin tinggi permukaan batugamping terekspose, semakin beser julat antara permuka-an batugamping dengan muka air tanah dan semakin baik sirkulasi air secara vertikal, serta semakin intensif proses karstifikasi.

Temperatur mendorong proses karstifikasi terutma dalam kaitannya dengan aktivitas organisme. Daerah dengan temperatur hangat seperti di daerah tropis merupakan tempat yang ideal bagi perkembangan organisme yang selanjutnya menghasilkan $\mathrm{CO}_{2}$ dalam tanah yang melimpah. Temperatur juga menentukan evaporasi, semakin tinggi temperatur semakin besar evaporasi yang pada akhirnya akan menyebabkan rekristalisasi larutan karbonat di permukaan dan dekat permukaan tanah. Adanya rekristalisasi ini akan membuat pengerasan permukaan (case hardening) sehingga bentuklahan karst yang telah terbentuk dapat dipertahankan dari proses denudasi yang lain (erosi dan gerak masa batuan).

Kecepatan reaksi sebenarnya lebih besar di daerah temperatur rendah, karena konsentrasi $\mathrm{CO}_{2}$ lebih besar pada temperatur rendah. Namun demikian tingkat pelarutan di daerah tropis lebih tinggi karena ketersediaan air hujan yang melimpah dan aktivitas organisme yang lebih besar.

Penutupan hutan juga merupakan faktor pendorong perkembangan karena hutan yang lebat akan mempunyai kandungan $\mathrm{CO}_{2}$ dalam tanah yang melimpah akibat dari hasil perombakan sisa-sisa organik (dahan, ranting, daun, bangkai binatang) oleh mikro organisme. Semakin besar konsentrasi $\mathrm{CO}_{2}$ dalam air semakin tinggi tingkat daya larut air terhadap batugamping. $\mathrm{CO}_{2}$ di atmosfer tidaklah bervariasi secara signifikan, sehingga variasi proses karstifikasi sangat ditentukan oleh $\mathrm{CO}_{2}$ dari aktivitas organisme. Hubungan antara konsentrasi $\mathrm{CO}_{2}$ dengan daya larut terhadap batu gamping ditunjukkan pada Gambar 1.2.

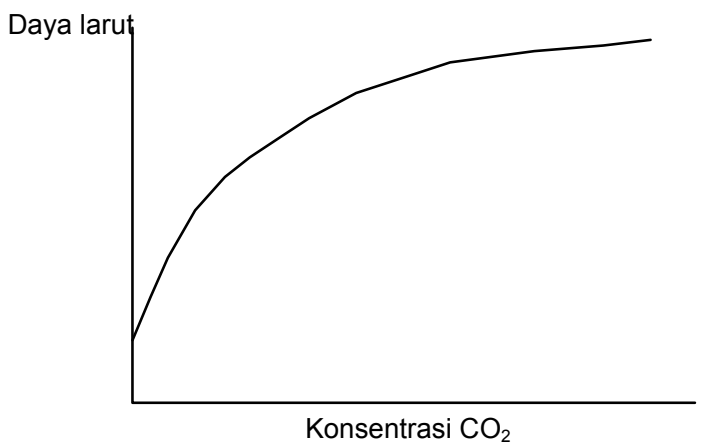

Gambar 1.2.

Hubungan antara konsentrasi $\mathrm{CO}_{2}$ dengan daya larut terhadap batu gamping

Faktor-faktor karstifikasi pengaruhnya terhadap proses pelarutan ditunjukkan pada Gambar 1.3.

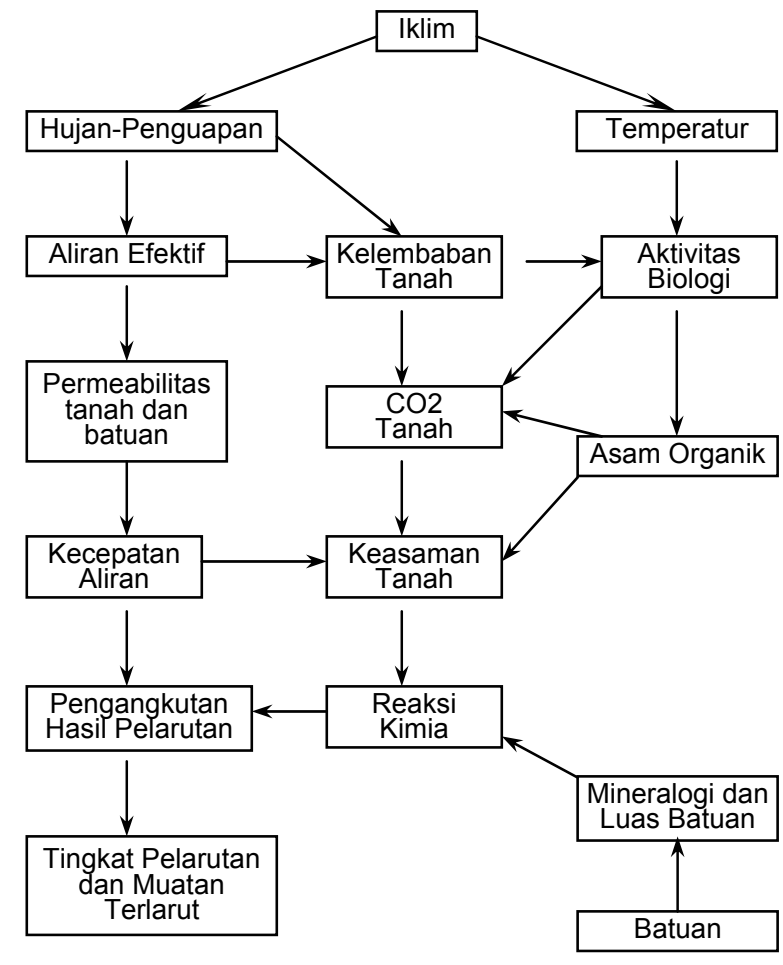

Gambar 1.3. Faktor-faktor karstifikasi pengaruhnya terhadap proses pelarutan (Trudgil, 1985) 


\section{KLASIFIKASI KARST}

Topografi karst telah banyak ditemukan di berbagai tempat di belahan bumi dengan berbagai tipe. Peneliti karst telah mencoba menjelaskan variasi karst dan mengklasifikasi tipe-tipe karst. Klasifikasi karst secara umum dapat dikategorikan menjadi tiga kelompok, yaitu 1) klasifikasi yang didasarkan pada perkembangan (Cvijic), 2) klasifikasi yang didasarkan pada morfologi, dan 3) klasifikasi yang didasarkan pada iklim (Sawicki, Lehmann, Sweeting). Beberapa klasifikasi karst berikut ini adalah klasifikasi Cvijic, Gvozdeckij dan Sweeting

\section{KLASIFIKASI CVIJIC (1914)}

Cvijic membagi topografi karst menjadi tiga kelompok, yaitu holokarst, merokarst, dan karst transisi.

Holokarst merupakan karst dengan perkembangan paling sempurna, baik dari sudut pandang bentuklahannya maupun hidrologi bawah permukaannya. Karst tipe ini dapat terjadi bila perkembangan karst secara horisontal dan vertikal tidak terbatas; batuan karbonat masif dan murni dengan kekar vertikal yang menerus dari permukaan hingga batuan dasarnya; serta tidak terdapat batuan impermeable yang berarti. Karst tipe holokarst yang dicontohkan oleh Cvijic adalah Karst Dinaric, Lycia, dan Jamaica. Di Indonesia, karst tipe ini jarang ditemukan, karena besarnya curah hujan menyebabkan sebagian besar karst terkontrol oleh proses fluvial.

Merokarst merupakan karst dengan perkembangan tidak sempurna atau parsial dengan hanya mempunyai sebagian ciri bentuklahan karst. Merokarst berkembang di batugamping yang relatif tipis dan tidak murni, serta khususnya bila batugamping diselingi oleh lapisan batuan napalan. Perkembangan secara vertikal tidak sedalam perkembangan holokarst dengan evolusi relief yang cepat. Erosi lebih dominan dibandingkan pelarutan dan sungai permukaan berkembang. Merokarst pada umumnya tertutup oleh tanah, tidak ditemukan karen, dolin, goa, swallow hole berekembang hanya setempatsetempat. Sistem hidrologi tidak kompleks, alur sungai permukaan dan bawah permukaan dapat dengan mudah diidentifikasi. Drainase bawah tanah terhambat oleh lapisan impermeabel. Contoh dari karst ini adalah karst di Batugamping Carbonferous Britain, Irlandia, Galicia Polandia, Moravia karst Devonian, dan karst di Prancis utara. Contoh merokarst di Indonesia diantaranya adalah karst di sekitar Rengel Kabupaten Tuban.

Karst Transisi berkembang di batuan karbonat relatif tebal yang memungkinkan perkembangan bentukan karst bawah tanah, akan tetapi batuan dasar yang impermeabel tidak sedalam di holokarst, sehingga evolusi karst lebih cepat; lembah fluvial lebih banyak dijumpai, dan polje hampir tidak ditemukan. Contoh dari karst transisi menurut Cvijic adalah Karst Causses Prancis, Jura, Plateux Balkan Timur, dan dan Dachstein. Contoh holokarst di Indonesia yang pernah dikunjungi penulis antara lain Karst Gunung Sewu (Gunungkidul, Wonogiri, dan Pacitan), Karst Karangbolong (Gombong), dan Karst Maros (Sulawesi Selatan).

\section{KLASIFIKASI GVOZDECKIJ (1965)}

Gvozdeckij mengklasifikasi karst berdasarkan pengamatannya di Uni Soviet (sekarang Rusia). Menurutnya karst dibedakan menjadi bare karst, covered karst, soddy karst, buried karst, tropical karst, dan permafrost karst.

Bare karst lebih kurang sama dengan karst Dinaric (holokarst)

Covered karst merupakan karst yang terbentuk bila batuan karbonat tertutup oleh lapisan aluvium, material fluvio-glacial, atau batuan lain seperti batupasir.

Soddy karst atau soil covered karst merupakan karst yang berkembang di batugamping yang tertutup oleh tanah atau terra rosa yang berasal dari sisa pelarutan batugamping.

Buried karst merupakan karst yang telah tertutup oleh batuan lain, sehingga bukti-bukti karst hanya dapat dikenalai dari data bor.

Tropical karst of cone karst merupakan karst yang terbentuk di daerah tropis.

Permafrost karst merupakan karst yang terbentuk di daerah bersalju.

\section{KLASIFIKASI SWEETING (1972)}

Karst menurut Sweeting diklasifikasikan menjadi true karst, fluviokarst, glaciokarst, tropical karst, arid an semiarid karst. Klasifikasi Sweeting terutama didasarkan pada iklim.

True karst merupakan karst dengan perkembangan sempurna (holokarst). Karst yang sebenarnya harus merupakan karst dolin yang disebabkan oleh pelarutan secara vertikal. Semua karst yang 
bukan tipe dolin karst dikatakan sebagai deviant. Contoh dari true karst menurut Sweeting adalah Karst Dinaric.

Fluviokarst dibentuk oleh kombinasi antara proses fluvial dan proses pelarutan. Fluviokarst pada umumnya terjadi di daerah berbatuan gamping yang dilalui oleh sungai alogenik (sungai berhilir di daerah non-karst). Sebaran batugamping baik secara lateral maupun vertikal jauh lebih kecil daripada true karst. Perkembangan sirkulasi bawah tanah juga terbatas disebabkan oleh muka air tanah lokal. Mataair muncul dari lapisan impermeable di bawah batugamping maupun dekat muka air tanah lokal. Lembah sungai permukaan dan ngarai banyak ditemukan. Bentukan hasil dari proses masuknya sungai permukaan ke bawah tanah dan keluarnya sungai bawah kembali ke permukaan seperti lembah buta dan lembah saku merupakan fenomena umum yang banyak dijumpai. Goa-goa di fluviokarst terbentuk di perbatasan antara batugamping dan batuan impermeabel di bawahnya oleh sungai alogenik dan berasosiasi dengan perkembangan sungai di daerah karst. Permukaan batugamping di fluviokarst pada umumnya tertutup oleh tanah yang terbentuk oleh erosi dan sedimetasi proses fluvial. Singkapan batugamping (bare karst) ditemukan bila telah terjadi erosi yang pada umumnya disebabkan oleh penggundulan hutan.

Glasiokarst merupakan karst yang terbentuk karena karstifikasi didominasi oleh proses glasiasi dan proses glasial di daerah yang berbatuan gamping. Nival karst merupakan karst yang terbentuk karena proses karstifikasi oleh hujan salju (snow) pada linkungan glasial dan periglasial. Glasiokarst terdapat di daerah berbatugamping yang mengalami glasiasi atau pernah mengalami glasiasi. Glasiokarst dicirikan oleh kenampakan-kenamapakan hasil penggogosan, erosi, dan sedimentasi glacier. Hasil erosi glacier pada umumnya membentuk limstone pavement. Erosi lebih intensif terjadi di sekitar kekar menhasilkan cekungan dengan lereng terjal memisahkan pavement satu dengan lainnya. Dolin-dolin terbentuk terutama disebabkan oleh hujan salju. Pencairan es menhasilkan ngarai, pothole, dan goa, Karakteristik lain dari glasiokarst adalah goa-gaoa yang terisi oleh oleh es dan salju. Contoh dari galsiokarst adalah karst di lereng atas pegunungan Alpen.

Tropical karst berbeda dengan karst di iklim sedang dan kutub terutama disebabkan oleh presipitasi dan evaporasi yang besar. Presipitasi yang yang besar menghasilkan aliran permukaan sesaat yang lebih besar, sedangkan evaporasi menhasilkan rekristalisasi larutan karbonat membentuk lapisan keras di permukaan. Hal ini menyebabkan dolin membulat seperti di iklim sedang jarang ditemukan digantikan oleh dolin berbentuk bintang yang tidak beraturan. Dolin tipe ini sering disebut kockpit. Di antara dolin ditemukan bukit-bukit yang tidak teratur disebut dengan bukit kerucut.

Karst tropis secara lebih rinci dibedakan menjadi dua kelompok, yaitu:

1. kegelkarst (sinoid karst, cone karst, atau karst a piton)

2. turmkarst (karst tower, pinacle karst, atau karst a tourelles)

Kegelkarst dicirikan oleh kumpulan bukit-bukit berbentuk kerucut yang sambung menyambung. Sela antar bukit kerucut membentuk cekungan dengan bentuk seperti bintang yang dikenal dengan kockpit. Kockpit seringkali membentuk pola kelurusan sebagai akibat kontrol kekar atau sesar. Depresi atau kockpit yang terkontrol kekar atau sesar ini oleh Lemann disebut gerichteter karst (karst oriente). Contoh kegelkarst di Indonesia antara lain Karst Gunungsewu dan Karst Karangbolong. Kenampakan kegelkarst dari foto udara dan peta topografi ditunjukkan pada Gambar 1.4.

Turmkarst/menara karst/pinacle karst merupakan tipe karst kedua yang sering dijumpai di daerah tropis. Tipe karst ini dicirikan oleh bukitbukit dengan lereng terjal, biasanya ditemukan dalam kelompok yang dipisahkan satu sama lain dengan sungai atau dataran aluvial. Tower karst dibentuk berkembang apabila pelarutan lateral oleh muka air tanah yang sangat dangkal atau oleh sungai alogenik yang melewati singkapan batugamping. Beberapa ahli beranggapan bahwa turmkarst merupakan perkembangan lebih lanjut dari kegelkarst karena kondisi hidrologi tertentu. Distribusi dan sebaran bukit menara pada umumnya dikontrol oleh kekar atau sesar. 

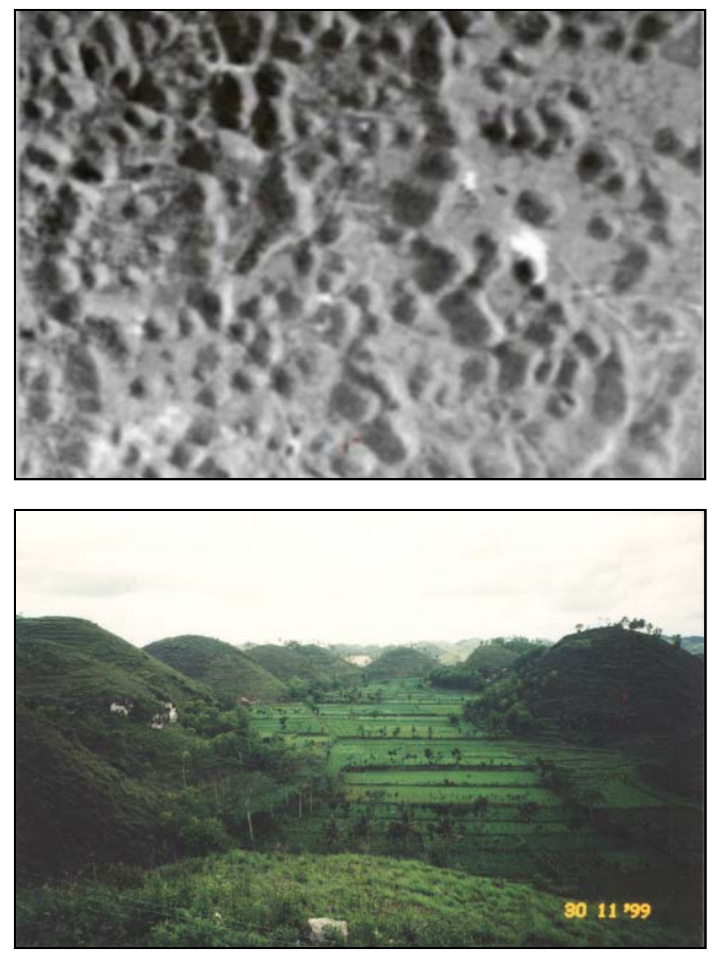

Gambar 1.4.

Kenampakan kegelkarst Gunungsewu dari foto udara dan lapangan
Ukuran bukit menara sangat bervariasi dari pinacle kecil hingga blok dengan ukuran beberapa kilometer persegi. Permukaan tidak teratur disebabkan oleh depresi-depresi dan koridor dengan dedalaman hingga 150 meter. Kontak dari bukit menara dengan dataran aluvium merupakan tempat pemunculan mataair dan perkembangan gua. Telaga dan rawa juga sering ditemukan di kaki dari bukit-bukit menara. Rawa yang relatif bersifat asam selanjutnya akan mempercepat pelarutan secara lateral membentuk bukit-bukit yang semakin curam hingga tegak. Bila muka tanah turun, rawa akan teratus dan ditutupi oleh endapan koluvium dari rombakan bukit menara, sehingga bukit menara berubah menjadi tidak curam (gambar 1.5.)

Karst menara dapat dibedakan menjadi dua kelompok. Pertama, bukit menara merupakan bukit sisa batugamping yang terisolir di antara rataan batugamping yang telah tertutup oleh endapan aluvium. Kedua, bukit menara merupakan bukit sisa dari batugamping yang berada di dataran dengan batuan non karbonat. Karst menara di Indonesia diantaranya dapat diketemukan di tepian Karst Maros yang berbatasan dengan dataran aluvial (sisi barat).

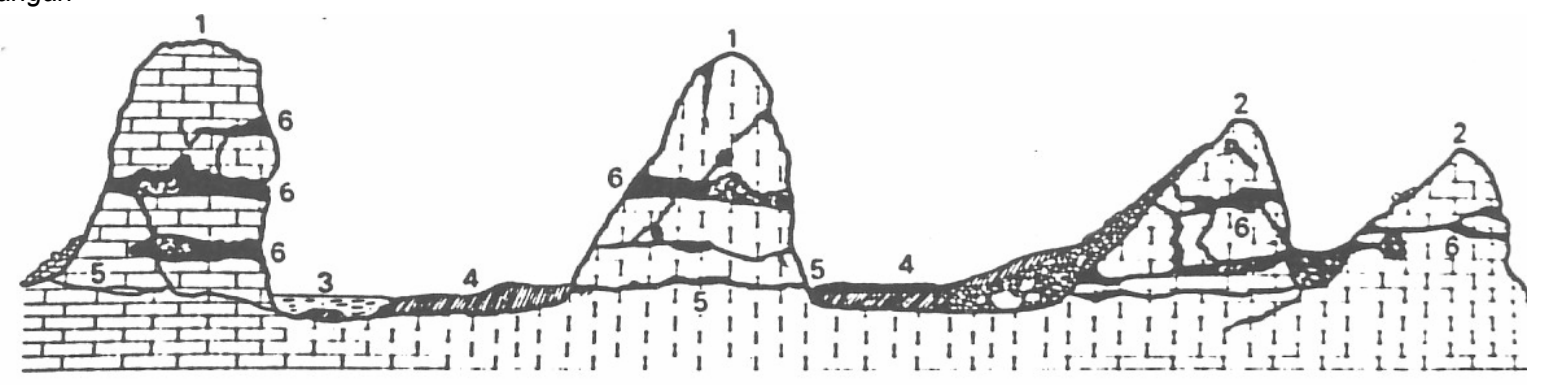

Gambar 1.5. Kenampakan karst tower.

1. Bukit karst menara terbentuk oleh erosi lateral, 2. Bukit karst kerucut, Sungai, 4. Dataran korosi Gua aktif, Gua fosil

(Sweeting, 1972)

\section{TIPE KARST YANG LAIN}

Selain klasifikasi di atas, literatur atau peneliti karst lain telah memberi nama tertentu untuk suatu kawasan karst. Penamaan yang digunakan hanya dimaksudkan untuk memberi nama tanpa bermasud mengklasifikasi secara sistematis. Beberapa tipe karst yang sering digunakan dan sering muncul di literatur karst antara lain labirynt karst dan polygonal karst.

Labyrint karst merupakan karst yang dicirikan oleh koridor-koridor atau ngarai memanjang yang terkontrol oleh kekar atau sesar. Morfologi karst tersusun oleh blok-blok batugamping yang dipisahkan satu sama lain oleh ngarai/koridor karst. Karst tipe ini terbentuk karena pelarutan yang jauh lebih intensif di jalur sesar dan patahan. 
Sebaliknya di tempat lainnya pelarutan tidak intensif. Karst labirint di Indonesia dapat dijumpai di Papua dan di sebagian Gunungsewu (Gambar 1.6.)
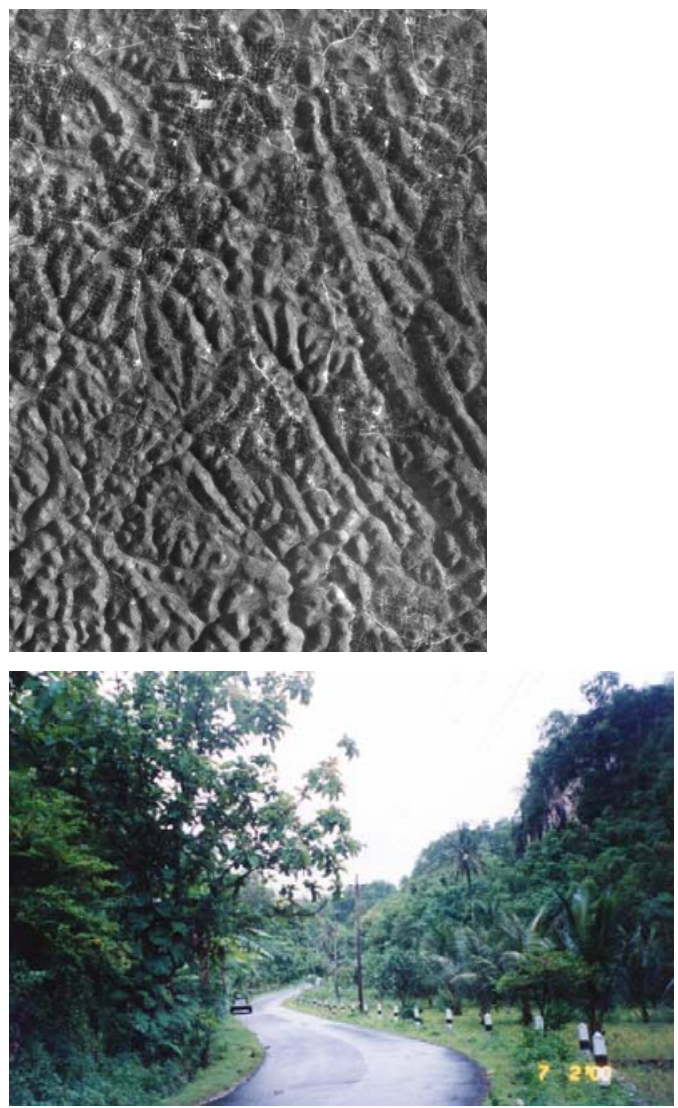

Gambar 1.6.

Kenampakan karst labirint

Karst Poligonal merupakan penamaan yang didasarkan dari sudut pandang morfometri dolin. Karst tipe ini dapat berupa karst kerucut maupun karst menara. Karst dikatakan poligonal apabila ratio luas dolin dangan luas batuan karbonat mendekati satu atau satu. dengan kata lain semua batuan karbonat telah berubah menjadi kumpulan dolin-dolin dan dolin telah bersambung satu dengan lainnya (Gambar 1.7.)

$$
\mathrm{Ad} / \mathrm{A}=1
$$

Ad : Luas keseluruhan dolin

A : Luas keseluruhan batuan karbonat
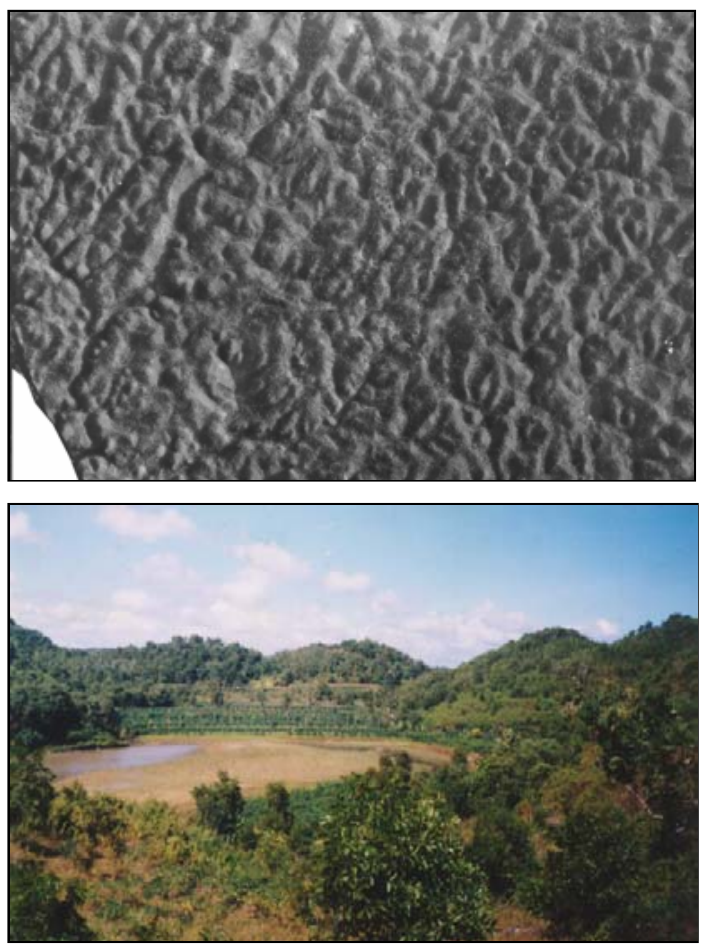

Gambar 1.7. Kenampakan karst plygonal

Karst Fosil merupakan karst yang terbentuk pada masa geologi lampau dan saat ini proses karstifikasinya sudah berhenti (Sweeting, 1972). Dalam hal ini karstifikasi tidak berlangsung hingga saat ini karena perubahan iklim yang tidak lagi mendukung proses karstifikasi. Karst fosil banyak diketukan di Baratlaut Yoksire-Ingris.

Karst fosil dapat dibedakan menjadi dua tipe. Pertama, karst yang terbentuk di waktu geologi sebelumnya dan tidak tertutupi oleh batuan lain. Tipe ini disebut dengan bentuklahan tinggalan (relict landform). Kedua, karst terbentuk di periode geologi sebelumnya yang kemudian ditutupi oleh batuan nonkarbonat. Bentuklahan karst tersebut selanjutnya muncul ke permukaan karena batuan atapnya telah tersingkap oleh proses denudasi. Tipe ini disebut dengan bentuklahan tergali (exhumed lanform). 
Dolinee berasal dari bahasa Slavia dolina yang berarti lembah. Istilah ini pertama kali digunakan sebagai istilah dalam geomorfologi oleh geologiwan Austria. Untuk menghindari kerancuan dengan dolinea = lembah, literatur karst Slovenia pada beberapa dekade telah menggunakan istilah dolinee yang dalam bahasa aslinya vrtaca.

Doline merupakan cekungan tertutup berbentuk bulat atau lonjong degan ukuran beberapa meter hingga lebih kurang satu kilometer (Ford dan Williams, 1992), sehingga Sweeting (1972) mengkategorikan doline dalam bentuklahan karst berskala sedang. Doline di literatur-literatur karst sering disebut dengan berbagai istilah, seperti sinkhole, sink, swallow holes, cenote, dan blue hole. Kemiringan lereng miring hingga vertikal dengan kedalaman beberapa meter hingga ratusan meter.

Doline merupakan bentuklahan yang paling banyak dijumpai di kawasan karst. Bahkan di daerah beriklim sedang, karstifikasi selalu diawali dengan terbentuknya doline tunggal akibat dari proses pelarutan yang terkonsentrasi. Tempat konsentrasi pelarutan merupakan tempat konsentrasi kekar, tempat konsentrasi mineral yang paling mudah larut, perpotongan kekar, dan bidang perlapisan batuan miring. Doline-doline tungal akan berkembang lebih luas dan akhirnya dapat saling menyatu.

Secara singkat dapat dikatakan bahwa karstifikasi (khususnya di daerah iklim sedang) merupakan proses pembentukan doline dan goa-goa bawah tanah, sedangkan bukitbukit karst merupakan bentukan sisa/residual perkembangan doline.

Setiap doline atau cekungan tertutup tersusun oleh tiga komponen (White, 1988).

1. Pengatus, yaitu saluran dengan permeabilitas tinggi yang mengatuskan air dalam doline ke sistem drainase bawah tanah.

2. Mintakat yang terubah oleh proses pelarutan di permukaan dan dekat permukaan batuan.
3. Tanah penutup, koluvium, endapan glasial, abu volkanik atau material lepas yang lain. Namun demikian di beberapa tempat, material permukaan absen.

\section{BENTUK DOLINE}

Bentuk doline sangat bervariasi dari satu tempat ke tempat lain. Bentuk doline didaerah iklim sedang cenderung lebih teratur dengan bentuk membulat hingga lonjong. Di daerah iklim tropis, bentuk doline tidak sesempurna doline di daerah iklim sedang, dalam hal ini doline di daerah iklim tropis mempunyai bentuk yang tidak teratur. Salah satu bentuk planar doline yang banyak ditenukan di daerah tropis adalah adalah bentuk seperti bintang.

Bentuk doline di daerah tropis yang menyerupai bintang disebut secara khusus dengan Cockpit. Istilah ini pertama digunakan untuk menyebut karst di Jamaika (Sweeting, 1972; White 1988). Cockpit berasal dari kata cock yang berarti ayam jantan dan pit yang berarti lubang, dengan kata lain di Jamaika cockpit merupakan lubang tempat menyabung ayam. Karena karst memiliki cekungan-cekungan seperti cockpit, maka karst di Jamaika disebut dengan cockpit land. Perbedaan doline di daerah iklim sedang dan tropis ditunjukkan pada Gambar 1.8.
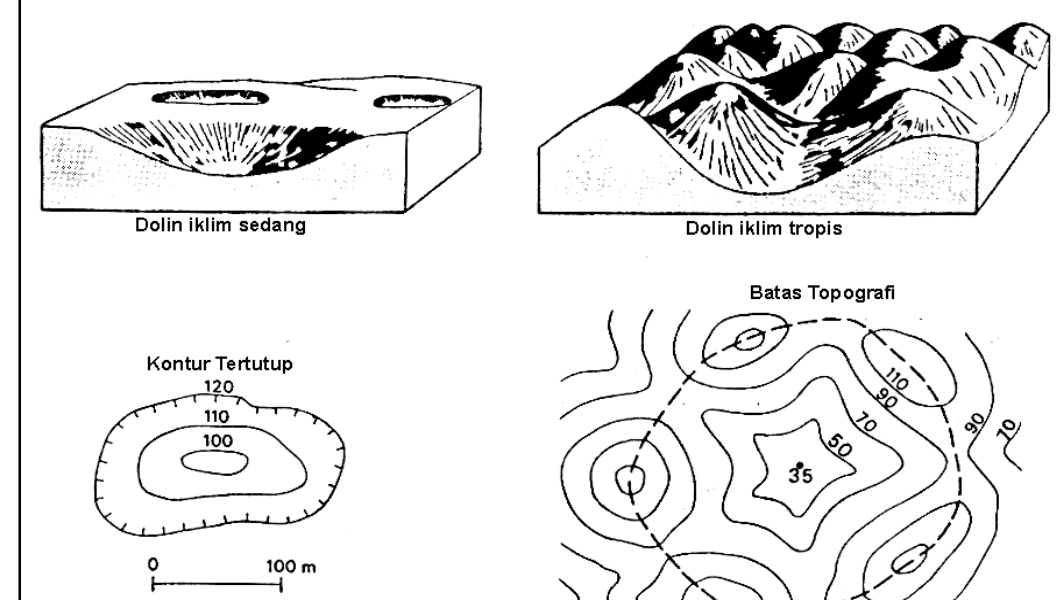

Gambar 1.8. Perbedaan doline di daerah iklim sedang dan di daerah tropis (Williams, 1969) 
Batas luar doline di daerah iklim sedang tergambar pada peta kontur berupa garis kontur tertutup, sedangkan batas luar doline di daerah tropis berupa batas topografi (topographic divide). Fenomena ini perlu mendapat perhatian bagi yang sedang membaca peta topografi di Indonesia. Peta topografi yang menggambarkan daerah karst sering memuat simbol doline seperti di daerah iklim sedang, tetapi sebenarnya simbol tersebut dimaksudkan untuk menggambarkan telaga/ danau doline atau dasar doline. Apabila seseorang bermaksud membatasi doline untuk studi morfometri doline harus tetap mendelineasi batas topografi sebagai batas luar doline

Secara planar doline dapat bebentuk bulat lonjong atau memanjang. Doline-doline memanjang terbentuk apabila perkembangan doline dikontrol oleh keberadaan kelurusan baik oleh sesar maupun kekar. Haryono (2000) menemukan bahwa doline memanjang lebih banyak ditemukan di kawasan karst Gunungsewu daripada bentuk doline yang yang membulat. Banyaknya doline memanjang di Karst Gunungsewu disebabkan oleh lereng regional yang miring ke arah selatan, keberadaan kekar dan sesar yang intensif, dan pengaruh dari proses fluvial. Kenamapakan doline memanjang dan cockpit di Karst Gunungsewu ditunjukkan pada Gambar 1.9.

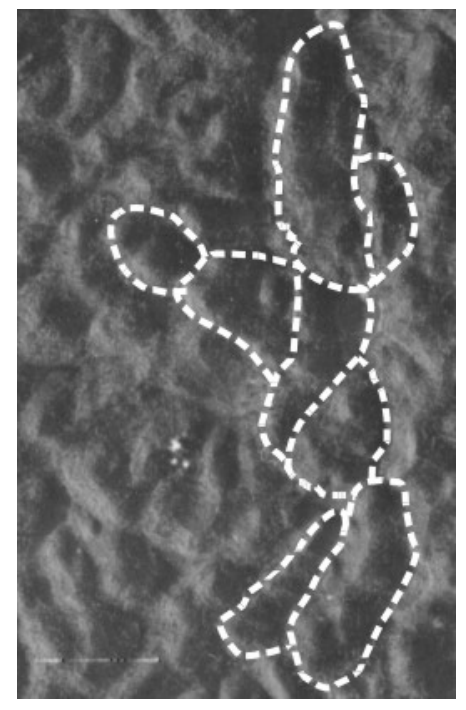

Gambar 1.9.

Kenampakan cockpit dan doline memanjang di Karst Gunungsewu
Doline, oleh Cvijic (1893) dikelompokkan menjadi tiga katergori yaitu doline mangkok, doline corong, dan doline sumur (Gambar 1.10)

Doline mangkok dicirikan oleh perbandingan lebar dan kedalaman 10:1 dan kemiringan lereng doline berkisar antara $10^{\circ}-12^{\circ}$. Dasar rata dan tertutup oleh tanah atau berawa.

Doline corong mempunyai diameter dua atau tiga kali kedalamannya dan lereng doline berkisar antara $30^{\circ}-40^{\circ}$, dengan dasar sempit dapat tertutup tanah maupun berupa singakapan batuan.

Doline sumuran dicirikan oleh diameternya yang lebih kecil dari kedalamannya, lereng vertikal berupa singkapan batuan.
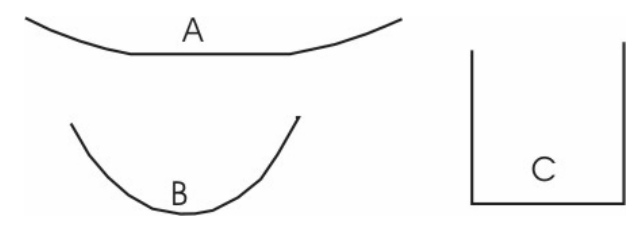

Bentuk-bentuk doline, A) doline mangkok, B) doline corong, dan C) doline Sumuran

Berdasarkan bentuknya, doline juga dapat dibedakan menjadi doline simetri dan doline asimetri. Doline simetri berbentuk bulat atu elip dengan kemiringan lereng ke segala arah yang hampir sama, sedangkan doline asimetri merupakan doline yang sisi satu dan lainnya mempunyai kemiringan lereng berbeda. Doline tidak simetri terbentuk karena perkembangan doline terkontrol oleh aliran permukaan dan struktur (Bogli, 1980) atau karena lereng (Williams,1985). Doline asimetri pertama terbentuk apabila doline terbentuk karena aliran permukaan yang masuk ke ponor, sisi dimana aliran permukaan masuk akan membentuk lereng yang lebih landai karena pelarutan yang lebih intensif, sedangkan sisi lainnya akan mem[unyai lereng yang lebih terjal. Doline asimetri struktural terbentuk pada batuan karbonat yang miring, dalam hal ini lereng doline yang searah dengan dip batuan akan membentuk kemiringan yang lebih landai, sedankan lereng yang berlawanan dengan dip batuan membentuk kemiringan yang lebih terjal (Gambar 1.11.) 


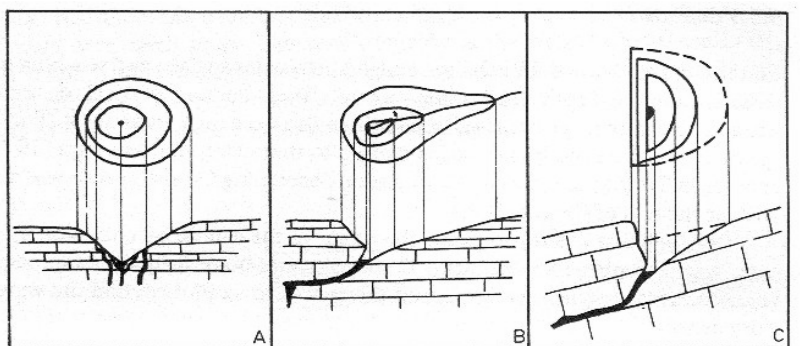

Gambar 1.11.

Kenampakan lateral dan vertikal (A) doline simetri,

(B) doline asimetri yang terkontrol oleh aliran permukan, dan

(C) doline asimetri yang terkontrol oleh perlapisan batuan

(Bogli, 1980)

Doline asimetri ke tiga terbentuk di daerah yang miring, dalam hal ini lereng lebih landai terbentuk di bagian atas dari lereng sedangkan lereng doline lebih terjal terbentuk bagian bawah lereng (Gambar 1.12.). Doline tipe ini dapat ditemukan di karst Gunungsewu (Ahmad, 1990) di lereng antara plato selatan dengan cekungan Wonosariu dan di lereng-lereng teras marin. Doline asimetri ini dikenali dari bukit-bukit karst yang terbentuk.

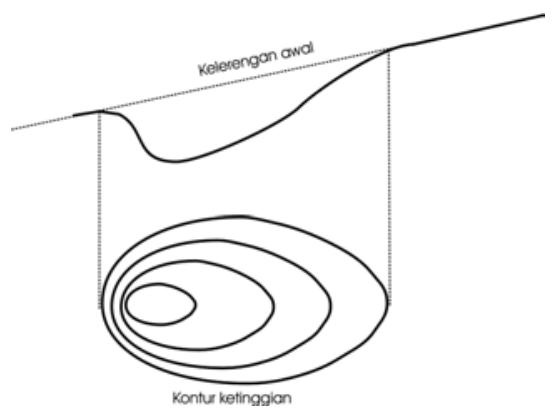

Gambar 1.12.

Doline asimetri yang berkembang di daerah yang miring (Williams, 1985).

\section{GENETIK DOLINE}

Bogli (1980) lebih lanjut berdasarkan cara pembentukannya (genetik) mengklasifikasikan doline menjadi doline pelarutan, doline aluvial, doline amblesan, dan dolin runtuhan.

Doline perlaturan terbentuk karena pelarutan yang terkonsentrasi akibat dari keberadaan kekar, pelebaran pori-pori batuan, atau perbedaan mineralogi batuan karbonat. Doline pelarutan terbentuk hampir disebagian besar awal proses karstifikasi.
Doline aluvial pada dasarnya merupakan doline pelarutan, namun dalam kasus ini batugamping tertutup oleh endapan aluvial. Cekungan tertutup yang terbentuk di endapan aluvial disebabkan oleh terbawanya endapan aluvium yang berada di atas rekahan hasil pelarutan ke sistem drainase bawah tanah. Infiltrasi melalui endapan aluvium membawa material halus ke sistem kekar di bawahnya yang berhubungan dengan goa-goa dalam tanah, sehingga endapan di atasnya menjadi cekung.

Doline amblesan terjadi apabila lapisan batugamping ambles secara perlahan-lahan karena di bawah lapisan batugamping terdapat rongga. Doline tipe ini dicirikan oleh terdapatnya rombakan batugamping dengan sortasi jelek di dasar doline dan lereng yang miring hingga terjal.

Doline runtuhan terbentuk apabila goa atau saluran dekat permukaan runtuh karena tidak mampu menahan atapnya. Bogli (1980) menjelaskan bahwa doline runtuhan terjadi bila runtuhan terjadi seketika, sedangkan doline amblesan terjadi secara perlahan-lahan. Doline tipe ini dicirikan oleh lereng curam hingga vertikal. Tiga mekanisme yang membentuk doline runtuhan adalah a) pelarutan di atas goa, b) pelarutan atap goa dari bawah, dan c) penurunan muka air tanah di atap goa (Gambar 1.14.).

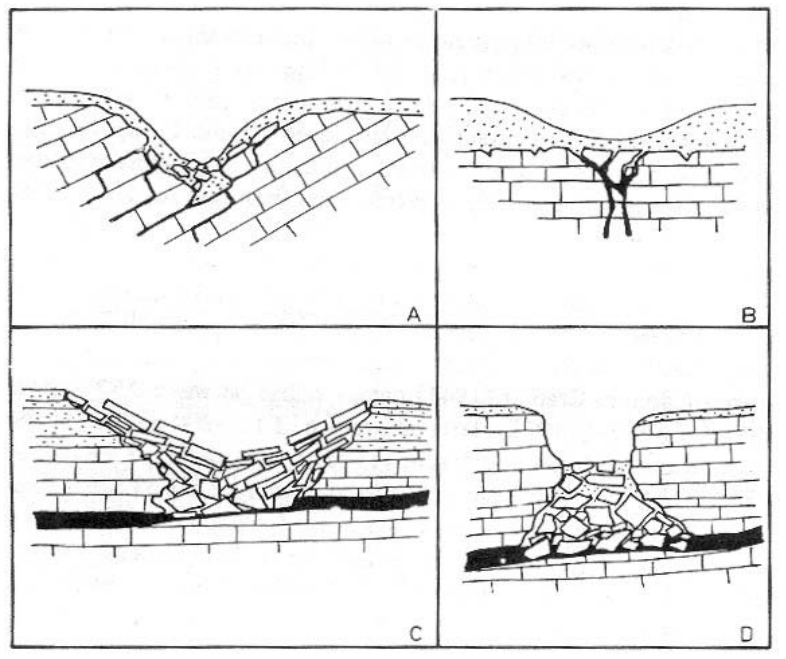

Gambar 1.13. Macam-macam doline menurut genetiknya (Ford dan Williams, 1992). 

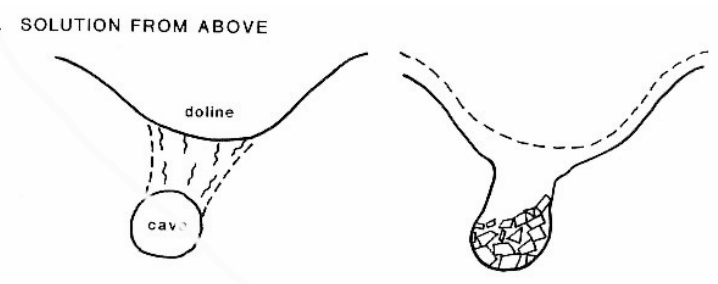

2. UNDERMINING FROM BELOW
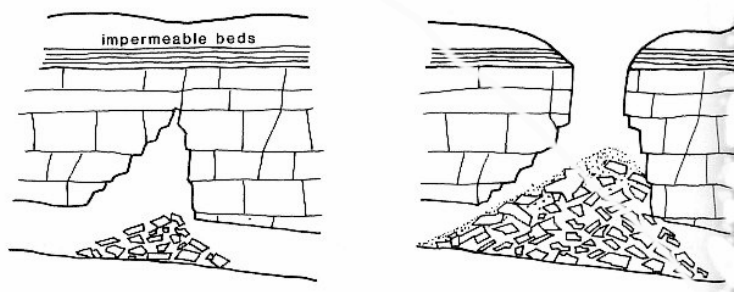

3. REMOVAL OF BUOYANT SUPPORT
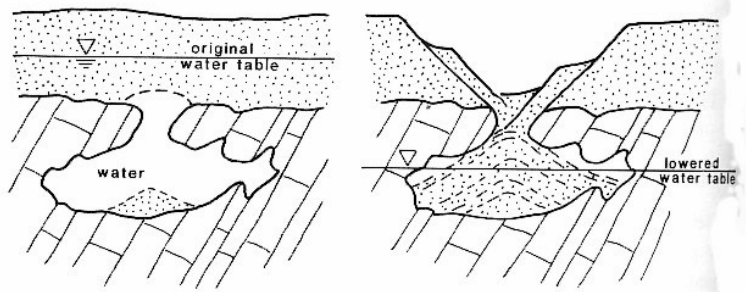

Gambar 1.14.

Mekanisme terbentuknya dolin runtuhan (Ford dan Williams, 1992)

Genetik doline inilah yang menyebabkan bentuk-bentuk dolin bervariasi seperti yang diutarakan oleh Cvijiv. Doline pelarutan dan doline aluvial membentuk doline tipe mangkok atau corong. Dolin amlesan membentuk dolin corong, sedangkan dolin membentuk dolin tipe sumuran. Perkembangan doline pelarutan merupakan fungsi dari produksi $\mathrm{CO}_{2}$ tanah, kinetika pelarutan, litologi, dan waktu. Doline pelarutan menurut Ford dan Williams (1993) dibedakan menjadi drawdown doline dan point recharge doline.

Drawdown doline merupakan doline pelarutan yang pembentukannya dikontrol oleh prosesproses hidrologi mintakat epikarst, yaitu suatu mintakat (zone) dekat permukaan dimana pelarutan terjadi intensif. Mintakat epikarst memupunyai ketebalan sekitar 10 meter (Williams, 1988). Pendapat ini didasarkan pada pengamatan Williams bahwa aliran permukaan di daerah karst sangat kecil dan hanya terjadi sesaat setelah hujan turun. Williams berpendapat bahwa sistem hidrologi di mintakat epikarst hampir sama dengan sistem hidrologi di daerah lain dengan aliran air tanah ke arah lateral. Arah aliran lateral ini bermuara di rekahan/celah batugamping karena kekar atau sesar membentuk muka airtanah yang cekung kedalam seperti muka air tanah endapan aluvial yang dipompa (Gambar 1.15).

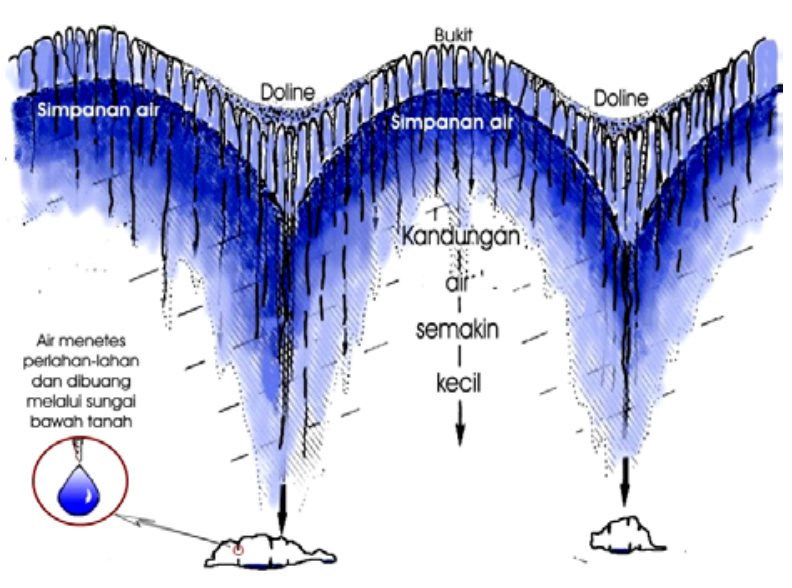

Gambar 1.15.

Doline dan hidrologi epikarst

Gambar 1.15. menunjukkan bahwa gradien hidraulik (kemiringan muka airtanah) mendekati pusat doline semakin besar, sehingga konduktivitas hidrolik juga semakin besar ke arah pusat doline. Pusat doline juga merupakan tempat bermuaranya/ berkumpulnya air dari lereng-lereng doline. Karena proses hidrologis inilah tejadi proses pelarutan yang terkonsentrasi sehingga membentuk doline.

Doline yang terbentuk selanjutnya secara umpan balik (feedback) akan mempengaruhi sistem hidrolologi mintakat epikarst. Doline yang semakin lebar akan menyebabkan meningkatnya aliran lateral, aliran lateral yang meningkat semakin mberbesar aliran yang terpusat, semakin besar aliran yang terpusat semakin cepat proses perkembangan doline, dan seterusnya.

Point recharge doline merupakan doline pelarutan yang terbentuk pada batugamping yang pada awalnya tertutup oleh batuan lain. Sebaliknya doline drawdown terbentuk pada 
batugamping yang tersingkap. Terbentuknya point recharge doline diawali oleh tersingkapnya batuan atap/penutup di satu tempat/titik, sehingga aliran permukaan masuk ke dalam lapisan batugamping dari titik tersebut. Masuknya aliran permukaan tersebut selanjutnya menyebabkan proses pelarutan yang terkonsentrasi yang semakin lamasemakin dalam membentuk cekungan tertutup. Erosi batuan atap yang terus berlangsung menyebabkan batugamping di bawanya tersingkap di beberapa tempat dengan frequensi yang semakin rapat menhasilkan titik-titik masuknya aliran permukaan ke lapisan batugamping dan doline yang semakin banyak.

\section{DOLINE MAJEMUK (UVALA)}

Doline majemuk (compound doline) di literatur karst sering disebut dengan uvala. Uvala merupakan gabungan dari doline-doline yang terbentuk di karst pada stadium perkembangan karst agak lanjut. Menurut Sweeting ukuran uvala berkisar antara 500-1000 meter dengan kedalaman 100-200 meter dengan ukuran tidak teratur. Cockpit dari sudut pandang ini dapat dianggap sebagai uvala atau doline majemuk yang berbentuk bintang, karena cockpit merupakan beberapa yang tepi atau sisi-sinya saling berhubungan/bergabung. Gabungan dari tepi-tepi doline inilah yang secara planar (tampak atas) membentuk bentuk-bentuk lancip seperti bintang Mengacu pada pandangan Grund tentang perkembangan karst, terbentuknya uvala merupakan ciri dari stadium adolescent karst atau perkembangan tahap II.

Uvala juga dapat perkembang dari lembah permukaan. Uvala tipe ini merupakan perkembangan akhir dari lembah permukaan yang terdegradasi. Perkembangan diawali oleh hilangnya aliran permukaan ke bawah tanah di titititik tertentu. Di tempat masuknya aliran permukaan ini selanjutnya doline berkembang yang semakin lama semakin dalam dan lebar, sehingga bergambung satu dengan lainnya membentuk uvala. Perkembangan doline menjadi uvala ditunjukkan pada Gambar 1.16, sedangkan permbandingan ukuran antara dolin, uvala, dan kockpit ditunjukkan pada Gambar 1.17.

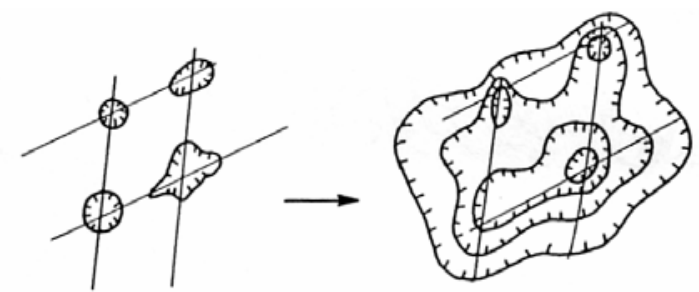

Perkembangan doline menjadi uvala

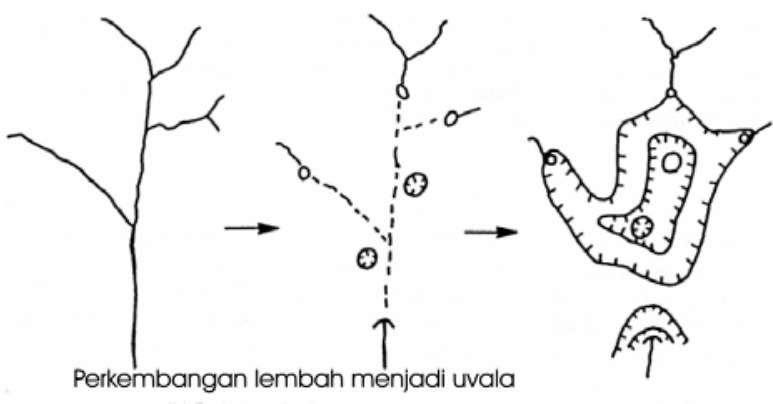

Gambar 1.16. Perkembangan uvala dari doline dan lembah kering (White, 1988)

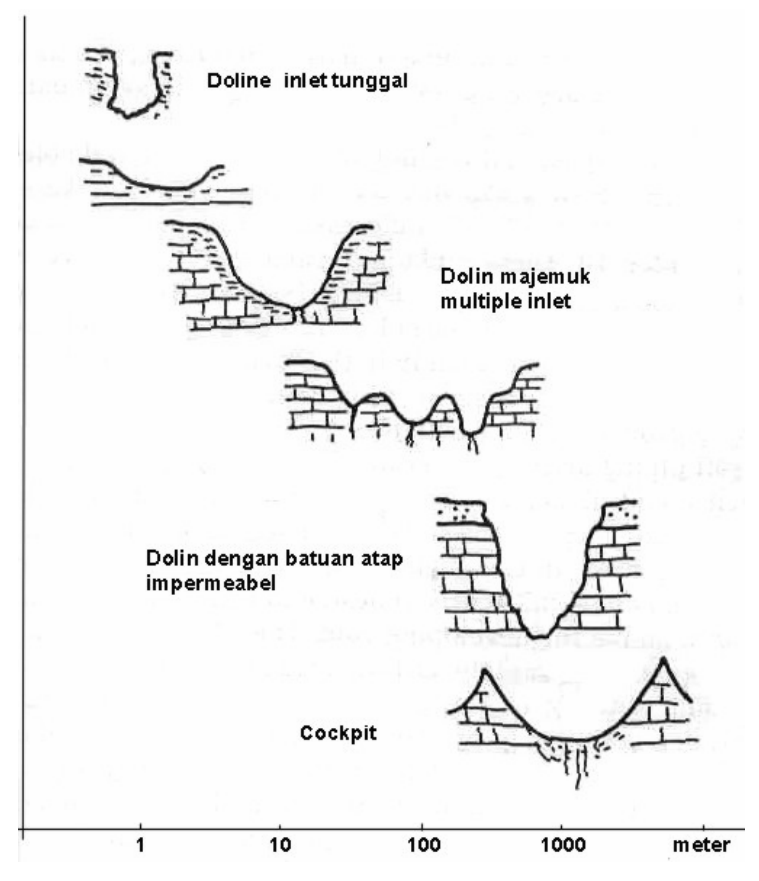

Gambar 1.17. Perbandingan ukuran dolin, uvala, dan cockpit (White, 1988). 


\section{MORFOMETRI DOLINE}

Morfometri doline merupakan ukuranukuran doline secara kuantitatif untuk melengkapi deskripsi karaktertistik kualitatif doline seperti diuraikan di atas. Ahli geomorfologi karst telah mencoba mengembangkan ukuran-ukuran doline untuk tujuan analisis secara kuantitatif. Analisis kuantitatif doline terutama dimaksudkan untuk karakterisasi doline secara lebih obyektif, mengingat istilah dan klasifikasi yang ada pada umumnya berasal dari satu tempat tertentu yang tidak sepenuhnya sesuai atau dapat diterapkan untuk daerah lain.

Analisis kuantitatif doline diawali oleh pembatasan/delineasi dolin dari foto udara secara stereoskopis (tiga demensi). Delineasi doline dianjurkan menggunakan foto udara dengan skala lebih besar dari 1:30.000. Skala yang paling baik adalah 1:15.000 tetapi skala 1:30.000 sudah dapat digunakan. Sedangkan delineasi foto udara skala 1:50.000 sangat sulit untuk dilakukan, mengingat pembatas topografi dengan ketinggian kurang dari lima meter tidak mudah untuk dikenali.

Di daerah tropis, delineasi dilakukan pada pembatas topografi, sedangkan delineasi di iklim sedang dilakukan pada tepi doline. Selain batas, delineasi juga harus dilakukan untuk lembahlembah kering yang bermuara ke doline. Contoh delineasi doline dintunjukkan pada Gambar 1.18.

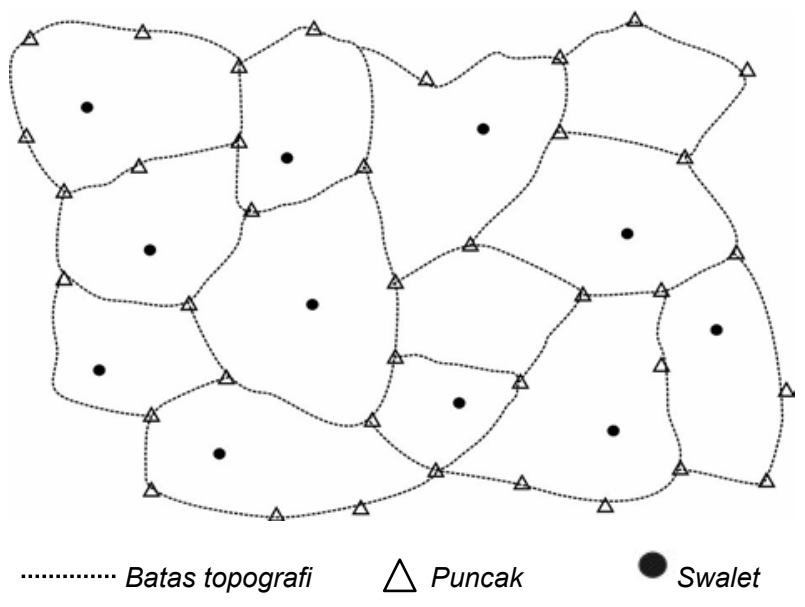

Gambar 1.18.

Contoh delineasi dolin
Selanjutnya, ukuran-ukuran yang digunakan untuk menya-takan morfometri doline ditunjukkan pada Tabel 1.1.

\section{Orde Doline}

Seperti halnya dengan lembah-lembah permu-kaan, doline dapat dinyatakan dalam orde. Orde doline menggambarkan tingkat perkembangan doline, semakin besar orde dolin berarti semakin lanjut perkembangan doline (gambar 1.19)
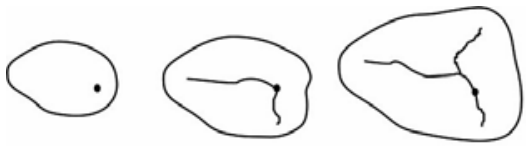

Orde 1

Orde 2

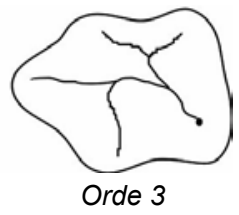

Gambar 1.19.

Sket yang menunjukkan orde doline

Tabel 1.1. Parameter Morfometri Doline

\begin{tabular}{|llc|}
\hline Ukuran & Definis & Unit \\
\hline Panjang & $L$ & $\mathrm{~m}$ \\
Lebar & $W$ & $\mathrm{~m}$ \\
Jumlah & $N_{D}$ & \\
Luas individul & $\mathrm{A}_{D}$ & $\mathrm{~m}^{2}$ \\
Luas keseluruhan kas & $A_{K}$ & $\mathrm{~m}^{2}$ \\
Luas rerata & $A_{D}=1 / N_{D} \Sigma A_{D}$ & $\mathrm{~m}^{2}$ \\
Ratio panjang dan lebar & $L 1+L 2 / W$ max & \\
Kepadatan & $D_{D}=N_{D} / A_{K}$ & \\
Rasio luas & $R_{D}=\Sigma A_{D} / A_{K}$ & \\
Indeks luas/pitting & $P i=A_{K} / \Sigma A_{D}$ & \\
\cline { 2 - 2 } & $(L 1+L 2+W$ max $) / 2$ & \\
diameter & $A i=\Sigma A_{D}$ & $\mathrm{~km}^{2}$ \\
Area runoff internal & \multicolumn{2}{c}{} \\
\hline
\end{tabular}




\section{POLJE}

Polje merupakan istilah di Karst Dinaric yang berasal dari bahasa Slovenia yang berarti ladang yang dapat ditanami. Istilah polje di negara asalnya tidak mempunyai kaitan dengan bentuklahan karst. Definisi formal pertama tentang polje dikemukaan oleh Cvijic tahun 1985 (dalam Gams, 1978) bahwa polje merupakan bentuklahan karst yang mempunyai elemen: cekungan yang lebar, dasar yang rata, drainase karstik, bentuk memanjang yang sejajar dengan struktur lokal, dasar polje mempunyai lapisan batuan Tersier. Publikasi selanjutnya oleh Cvijic (1990) mengungkapkan bahwa polje merupakan bentukan dari evolusi/perkembangan uvala.

Saat ini istilah polje telah diadopsi dalam terminologi karst. Definisi polje telah banyak dikemukakan dalam literatur karst, namun satu sama lain masih membingungkan. Hal ini dapat dimengerti mengingat setiap literatur mengkaji daerah yang berbeda. Gams (1978) telah mecoba mengali lebih dalam pengertian polje dan klasifikasinya berdasarkan fenomena di daerah asalnya. Polje di Karst Dinarik mempunyai lebar $400 \mathrm{~m}$ hingga $5 \mathrm{~km}$ dengan panjang hingga mencapai $60 \mathrm{~km}$, luas terkecil $3 \mathrm{~km}^{2}$ dan luas terbesar $474 \mathrm{~km}^{2}$. Dasar poje pada umumnya rata dan dikelilingi oleh perbukitan karst yang terjal. Morfologi Polje di Karst Dinarik ditunjukkan pada Gambar 1.20.

Berdasarkan data dari 42 poje yang ada di Karst Dinarik-Yugoslvia, Gams menyimpulkan bahwa polje mempunyai karakteristik minimal sebagai berikut:

1. dasar yang rata dapat merupa batuan dasar (dapat berteras) maupun tertutup sedimen lepas atau aluvium,

2. cekungan tertutup yang dibatasi oleh perbukitan dengan lereng terjal pada dua sisi atau salah satu sisinya,

3. mempunyai drainase karstik, dan

4. jika ketiga syarat tersebut dipenuhi, dasar yang rata harus mempunyai lebar minimum 400 meter.

Syarat lebar dari polje banyak dipermasalahkan oleh peneliti karst, karena lebar polje sangat tergantung pada daerah atau lokasi dari kawasan karst. Cvijic mengemukakan bahwa polje harus memiliki lebar minimum 1000 meter. Mengingat perbedaan batasan-batasan polje, beberpa ahli karst lebih cenderung mendefinisikan polje secara kualitatif berdasarkan pada genetik dan morfologi.

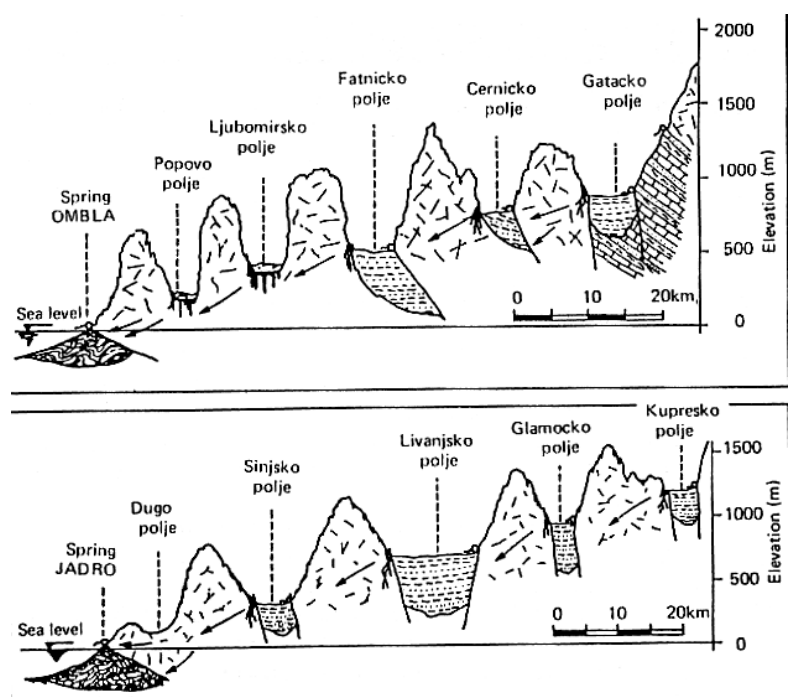

Gambar 1.20

Dua penampang melingtang Karst Dinarik yang menggambar morfologi polje (Mijatovic dalam White, 1988)

Selanjutnya, Gams (1978) mengklasifikasi ke 42 polje di Karst Dinarik menjadi lima kategori, yaitu border polje, over-flow polje, peripheral polje, diedmont polje, piezometric level polje.

Ford dan Williams (1992) selanjutnya menyederhanakan klasifikasi polje menjadi tiga kelompok, yaitu border polje, structural polje, dan baselevel polje (Gambar 1.21.)

Poje perbatasan terbentuk apabila sistem hidrologi didominasi oleh masukan air alogenik (dari luar sistem karst). Polje tipe ini berkembang apabila muka air tanah di batuan non karst terhampar hingga batuan karbonat.

Poje struktural terbentuk karena dikontrol struktur, biasanya berasosiasi dengan graben dan atau sesar miring dengan batuan impermeabel di dalamnya.

Poje baselevel terbentuk apabila regional muka air tanah memotong permukaan tanah. Polje tipe ini pada umumnya terbentuk di bagian bawah (outflow) dari kawasan karst. 
Poje baselevel, jika ditinjau dari perkembangan karst, terbentuk pada tahap akhir perkembangan

1. BORDER POLJE

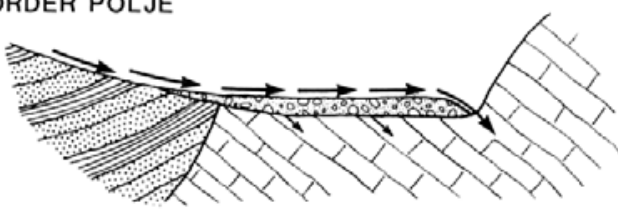

terjal hanya di salah satu sisinya akibat dari sesar. Karakteristik hidrologi didominasi olen keluarnya mataair-matair karst. Kedalaman airtanah kurang dari satu meter. Pemunculan mataair menjadikan air permukaan di Poje Ponjong melimpah dan oleh penduduk setempat digunakan untuk air irigasi. Dengan demikian penggunaan lahan dominan di Poje Ponjong berupa sawah irigasi.
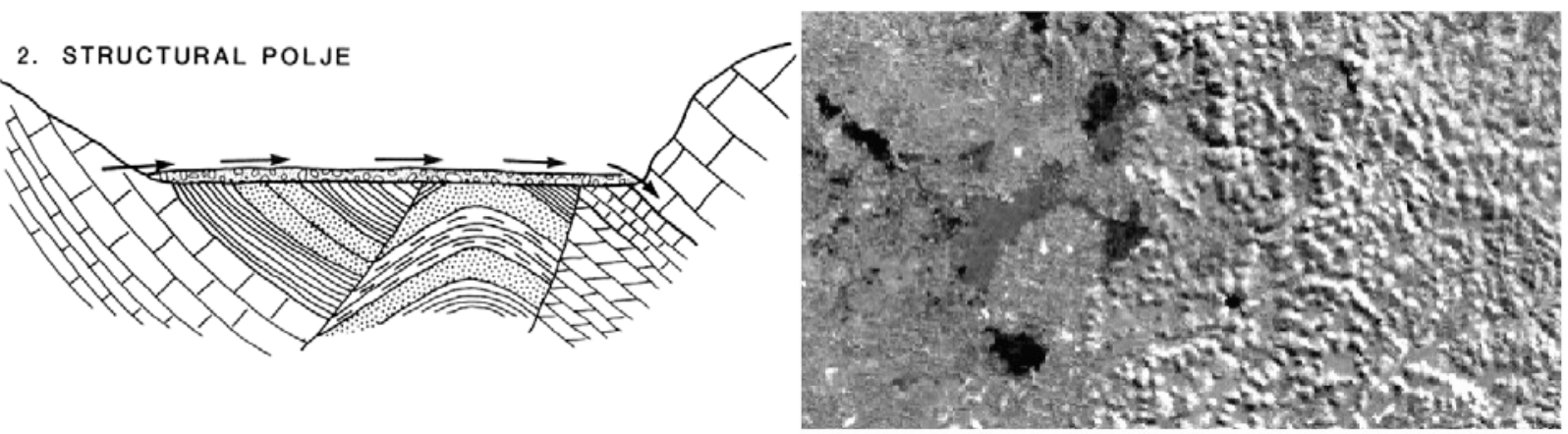

3. BASELEVEL POLJE

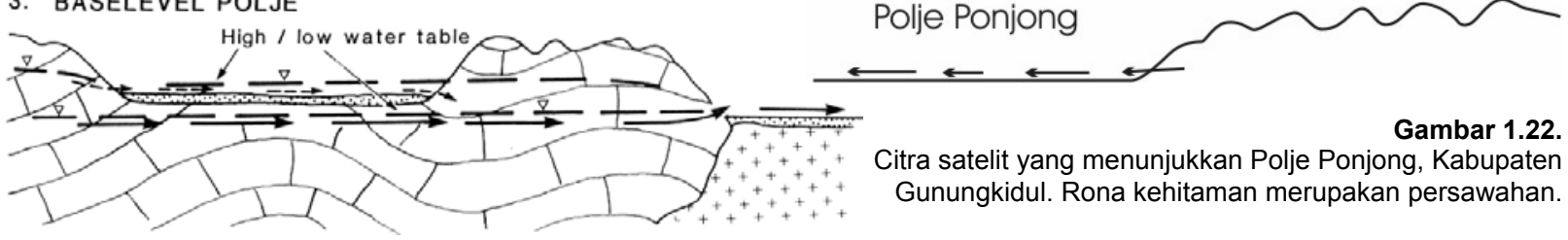

Gambar 1.21.

Tipe-tipe poje menurut Ford dan Williams, 1989

karst. Pada tahap ini korosi secara vertikal telah mencapai muka airtanah, sehingga korosi lebih dominan ke arah lateral. Korosi lateral menyebabkan bukit-bukit karst terdegradasi yang pada akhirnya rata dengan muka airtanah membentuk dataran yang luas. Karena airtanah sangat dangkal, fluktuasinya pada musim penghujan polje sering tergenang. Pada musim kemarau muka air tanah kurang dari satu meter. Kondisi air yang melimpah inilah yang menyebabkan polje merupakan daerah yang paling subur di daerah karst. Polje di Karst Maros dan Gunungsewu digunakan untuk persawahan. Di Karst Dinarik, polje merupakan pusat-pusat permukiman.

Polje struktural dapat dijumpai di sekitar Ponjong, Gunung Kidul, DIY (gambar 1.22). Poje di Ponjong merupakan polje yang dibatasi tebing
Polje base level dijumpai di Karst Maros, yaitu diperbatasan antara Daimanggala dan Bonto-bonto di bagian timur karst maros dengan lebar 1 dan 2,5 km. Dasar polje berupa endapan alucium dari material volkanik yang terbawa oleh sungai alogenik. Sungai-sungai alogenik ini selanjutnya masuk ke bawah permukaan menjadi sungai-sungai bawah tanah. 


\section{MORFOLOGI MIKRO}

Morfologi mikro daerah karst dalam literatur dan artikel karst diistilahkan dengan karren (bahasa Jerman) atau lapies (bahasa Prancis). Dimensi karren bervariasi dari 1 hingga 10 meter, sedangkan mikro karen mempunyai dimensi kurang dari $1 \mathrm{~cm}$ (Ford dan Williams, 1992). Karren dapat diklasifikasikan menjadi empat kelompok, yaitu bentuk membulat, bentuk memanjang yang terkontrol oleh kekar, bentuk linier yang terkontrol proses hidrolik, dan bentuk poligonal.

\section{a. Bentuk membulat}

Micropit : ukuran kurang dari $1 \mathrm{~cm}$.

Pits : bulat atau lonjong, bentuk tidak teratur, diameter $>1 \mathrm{~cm}$.

Pans : bulat atau lonjong dengan bentuk tidak teratur, dasar horisontal berupa batuan dasar atau endapan isian.

Heelprints atau Trittkarren : dinding terjal di bagaian ujung, dasar datar, terbuka di bagian bawah, diameter $10-30$ $\mathrm{cm}$.

Shafts atau well : bagian dasar saling berhubungan membentuk protocave yang mengatus air ke mintakat epikarst.

\section{b. Bentuk linier : terkontrol kekar}

Microfissures : dasar kacip, panjang beberapa $\mathrm{cm}$ dengan kedalaman kurang dari $1 \mathrm{~cm}$.

Splitkarren : kenamapakan pelarutan yang dikontrol oleh kekar, stylolite atau vein. Dasar lancip, panjang bervariasi dari sentimeter hingga beberapa meter, kedalaman beberapa sentimeter. Kedua ujungnya dapat terbuka atau tertutup.

Grikes atau Kluftkaren : hasil solusional yang dikontrol oleh kekar mayor atau sesar. Panjang 1 hingga 10 meter. Apabila di bawah tanah disebut cutter. Kumpulan kluftkarren dipisahkan satu dengan lainnya dengan clint. c. Bentuk linier : terkontrol oleh hidrodinamik Microrills : lebar lebih kurang $1 \mathrm{~mm}$. Aliran air terkontrol oleh tenaga kapilar, gravitasi, atau angin.

\section{d. Saluran pelarutan secara gravitatif}

Rillenkarren : kumpulan saluran mulai dari igir, lebar $1-3 \mathrm{~cm}$. Dipicu oleh air hujan. Bagian bawah menghilang.

Solutional runnels : Saluran mengikuti hukum Horton. Berkembang mulai dari sebelah bawah erosi lembar. Pada singkapan batuan dicirikan oleh tepi yang curam (Rinnenkarren), bulat jika tertutup tanah (Rundkarren). Saluran meluas ke arah bawah. Lebar $3-30 \mathrm{~cm}$, panjang $1-10 \mathrm{~m}$. Pola aliran linier, dendritik, atau sentripetal.

Decantation runnels : pelarutan terjadi di bagian atas pada satu titik, ke arah bawah saluran menyempit. Ukuran bervariasi hingga mencapai panjang lebih dari $100 \mathrm{~m}$, seperti wall karren (wandkarren), Maanderkarren.

Decantation flutings : pelarut berasal dari sumber diffuse pada lereng atas. Saluran padat, ke arah bawah kadang-kadang semakin berkurang.

Fluted scallops atau solution ripples : flute seperti ripple dengan arah sesuai arah aliran. Banyak variasi dari scallop. Banyak ditemukan sebagai komponen dari cockling pattern di singkapan batuan berlereng curam.

\section{e. Bentuk poligonal}

Karrenfield : istilah umum untuk hamparan karren yang tersingkap.

Limestone pavement : tipe dari karrenfield yang didominasi oleh clints yang teratur (flachkarren) dan grikes (kluftkarren).

Pinnacle karst : topografi yang runcingruncing, kadang terbuka karena erosi tanah. Arete, pinacle, dan stone 
forest kadang mempunyai pinacle dengan tinggi $45 \mathrm{~m}$ dan spasi $50 \mathrm{~m}$.

Ruiniform karst : Grike yang lebar dengan clint yang sudah terdegradasi. Bentuk peralihan ke tors.

Corridor karst (labyrinth karst, giant grike land) : skala besar dari grike dan clints dengan lebar beberapa meter dan panjang hingga $1 \mathrm{~km}$.

Coastal karren : karren di darah pantai atau lakustrin, termasuk intertidal dan subtidal notch, pits, pans, mikropits. 


\section{HIDROLOGI KARST}

\section{PENDAHULUAN}

Pada awalnya, berbicara mengenai hidrologi karst tentunya mempunyai konsekwensi logis yang dapat terbagi menjadi dua topik pembicaraan utama yaitu hidrologi dan karst. Hidrologi , menurut Linsley et. al. (1975) adalah cabang dari ilmu geografi fisik yang berurusan dengan air dimuka bumi dengan sorotan khusus pada sifat, fenomena dan distribusi air di daratan. Hidrologi dikategorikan secara khusus mempelajari kejadian air di daratan/bumi, deskripsi pengaruh sifat daratan terhadap air, pengaruh fisik air terhadap daratan dan mempelajari hubungan air dengan kehidupan. Pada sisi yang lain, karst dikenal sebagai suatu kawasan yang unik dan dicirikan oleh topografi eksokarst seperti lembah karst, doline, uvala, polje, karren, kerucut karst dan berkembangnya sistem drainase bawah permukaan yang jauh lebih dominan dibandingkan dengan sistem aliran permukaannya (Adji dkk, 1999).
Jika kita belajar hidrologi secara umum pasti tidak akan pernah lepas dari siklus hidrologi, yaitu peredaran air di bumi baik itu di atmosfer, di permukaan bumi dan di bawah permukaan bumi. Selama siklus tersebut, air dapat berubah wujudnya yaitu padat, cair maupun gas tergantung dari kondisi lingkungan siklus hidrologi. Jumlah air dalam siklus hidrologi selalu tetap dan hanya berubah distribusinya saja dari waktu ke waktu akibat adanya pengaruh dari faktor tertentu (Adji dan Suyono, 2004). Siklus hidrologi secara umum disajikan pada Gambar 2.1. Seperti disebutkan diatas, karena sifatnya, fokus dari hidrologi karst adalah bukan pada air permukaan tetapi pada air yang tersimpan di bawah tanah pada sistem-sistem drainase bawah permukaan karst. Untuk lebih jelasnya, Gambar 2.2 mengilustrasikan drainase bawah permukaan yang sangat dominan di daerah karst.

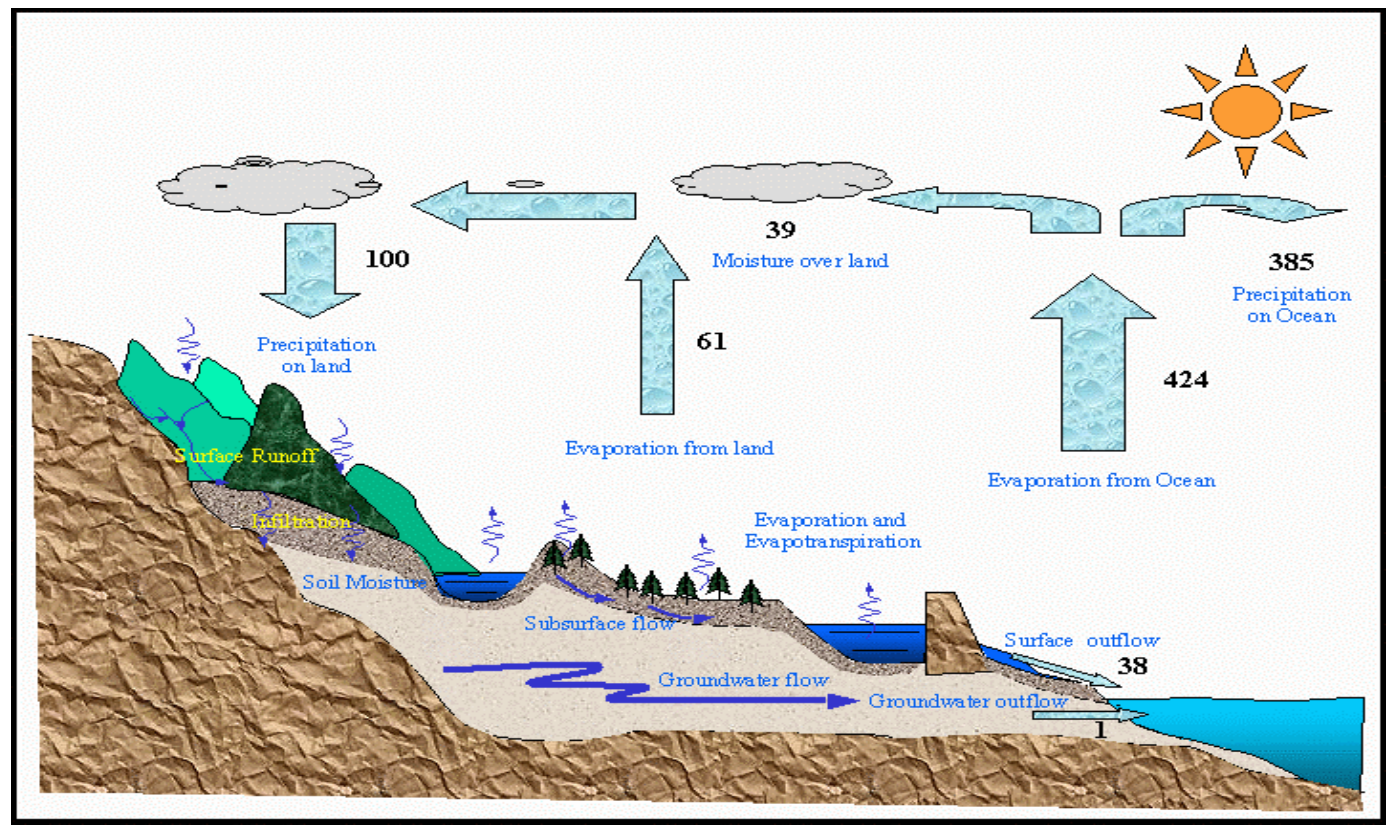

Gambar 2.1. Siklus Hidrologi (Sumber: www.ecn.purdue/edu/.../gishyd.html) 


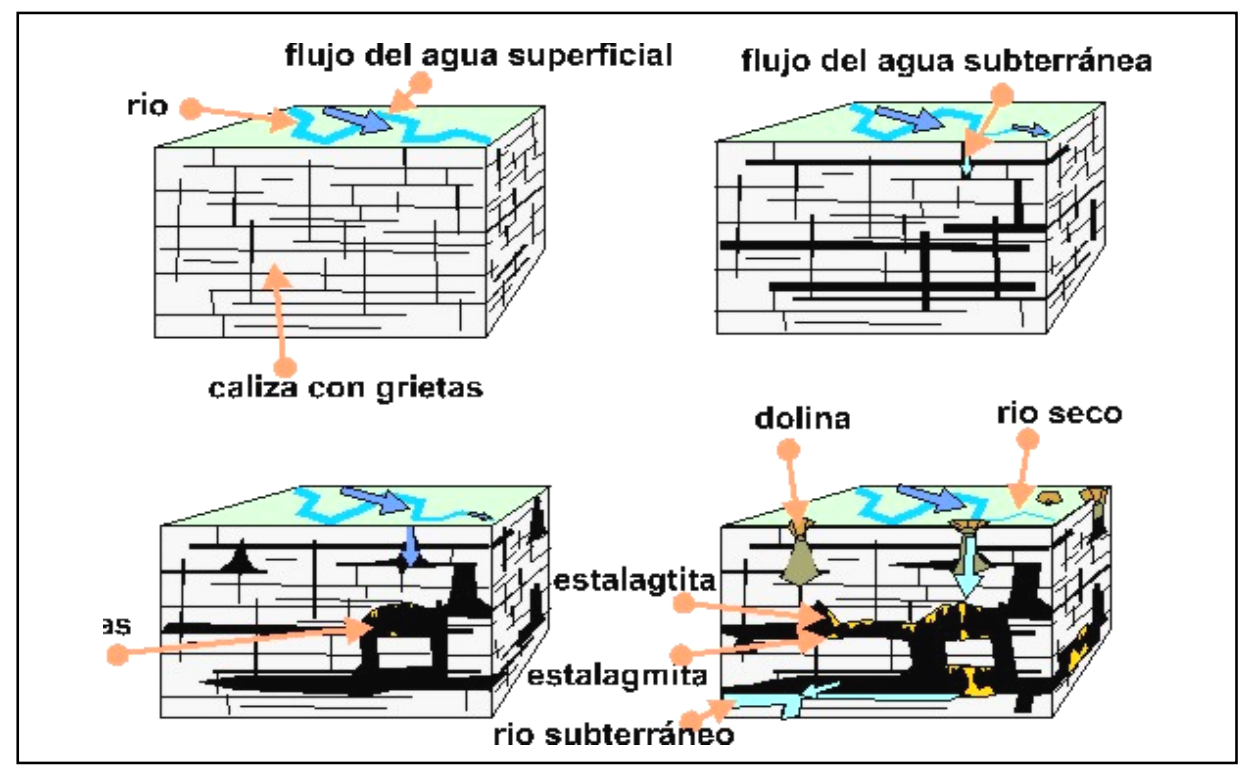

Gambar 2.2. Drainase bawah permukaan di daerah karst

(Sumber: http://www.eccentrix.com/members/hydrogeologie/hidrogeol/karst.gif)

Dari Gambar 2.2 terlihat bahwa karena sifat batuan karbonat yang mempunyai banyak rongga percelahan dan mudah larut dalam air, maka sistem drainase permukaan tidak berkembang dan lebih didominasi oleh sistem drainase bawah permukaan. Sebagai contoh adalah sistem pergoaan yang kadang-kadang berair dan dikenal sebagai sungai bawah tanah. Selanjutnya, dalam bahasan ini akan lebih banyak dideskripsikan hidrologi karst bawah permukaan yang selanjutnya akan kita sebut sebagai airtanah karst. Secara definitif, air pada sungai bawah tanah di daerah karst boleh disebut sebagai airtanah merujuk definisi airtanah oleh Todd (1980) bahwa airtanah merupakan air yang mengisi celah atau pori-pori/rongga antar batuan dan bersifat dinamis. Sedangkan, air bawah tanah karst juga merupakan air yang mengisi batuan/percelahan yang banyak terdapat pada kawasan ini, walaupun karakteristiknya sangat berbeda dibandingkan dengan karakteristik airtanah pada kawasan lain.

Pada daerah non-karst, dengan mudah kita dapat membedakan antara sistem hidrologi permukaan dan bawah permukaan. Secara sederhana, konsep Daerah Aliran Sungai (DAS) dapat dianggap sebagai unit untuk mengkaji sistem hidrologi baik itu permukaan maupun bawah permukaan. DAS sering pula dikenal sebagai drainage basin (cekungan yang mempunyai sistem aliran) yang mempunyai karakteristik aliran permukaan dan bawah permukaan dan keluar melalui satu outlet dibatasi oleh batas topografi berupa igir. Batas dari DAS dapat dikatakan selalu tetap dan tidak berubah sepanjang masa, terutama jika kita berbicara mengenai air permukaan. Sementara itu, sistem airtanah (akuifer) dapat memotong batas topografi DAS dan menjadi bagian dari beberapa DAS. Sebaliknya, konsep DAS aliran permukaan di daerah karst sulit dikenali karena lebih berkembangnya bawah permukaan. Kenyataan yang ada adalah banyaknya lorong-lorong hasil proses solusional dan sangat sedikitnya aliran permukaan.

Jankowski (2001) mengatakan bahwa terdapat tiga komponen utama pada sistem hidrologi karst, yaitu : akuifer, sistem hidrologi permukaan, dan sistem hidrologi bawah permukaan. Di karst, cekungan bawah permukaan dapat diidentifikasi dengan mencari hubungan 
antara sungai yang tertelan (swallow holes) dan mata air. Cekungan bawah permukaan ini dapat berkorelasi dengan cekungan aliran permukaan (DAS) jika jalur-jalur lorong solusional pada bawah permukaan utamanya bersumber pada sungai permukaan yang masuk melalui ponor. Tapi, secara umum batas antara DAS permukaan dan bawah permukaan adalah tidak sama. Sistem bawah permukaan, terutama yang memiliki kemiringan muka airtanah yang rendah dapat mempunyai banyak jalur dan outlet (mataair). Selanjutnya, karena terus berkembangnya proses pelarutan, muka airtanah, mataair dan jalur sungai bawah tanah di akuifer karst juga dapat berubahubah menurut waktu.

\section{AKUIFER KARST}

Akuifer dapat diartikan sebagai suatu formasi geologi yang mampu menyimpan dan mengalirkan airtanah dalam jumlah yang cukup pada kondisi hidraulik gradien tertentu (Acworth, 2001). Cukup artinya adalah mampu mensuplai suatu sumur ataupun mata air pada suatu periode tertentu. Dapatkah formasi karst yang didominasi oleh batuan karbonat disebut sebagai suatu akuifer?. Jawaban dari pertanyaan ini dapat kita kembalikan dari definisi akuifer seperti yang telah disebutkan di atas. Jika formasi karst dapat menyimpan dan mengalirkannya sehingga sebuah sumur atau mataair mempunyai debit air yang cukup signifikan, maka sah-sah saja jika formasi karst tersebut disebut sebagai suatu akuifer. Perdebatan mengenai hal ini sudah terjadi terutama pada masa-masa lampau dan solusi yang ada biasanya tergantung dari sudut hidrogeologis mana kita memandangnya. Selanjutnya, dua hal ekstrim pada akuifer karst adalah adanya sistem conduit dan diffuse yang hampir tidak terdapat pada akuifer jenis lain (White, 1988). Ada kalanya suatu formasi karst didominasi oleh sistem conduit dan ada kalanya pula tidak terdapat lorong-lorong conduit tetapi lebih berkembang sistem diffuse, sehingga hanya mempunyai pengaruh yang sangat kecil terhadap sirkulasi airtanah karst. Tetapi, pada umumnya suatu daerah karst yang berkembang baik mempunyai kombinasi dua element tersebut. Gambar 2.3 menunjukkan sistem conduit, diffuse, dan campuran pada formasi karst. Selain itu menurut Gillison (1996) terdapat satu lagi sistem drainase di daerah karst yaitu sistem rekahan (fissure). Ketiga istilah ini akan dibahas lebih lanjut pada subbab yang lain. (a)

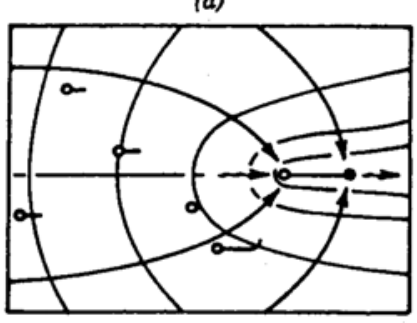

Diffuse

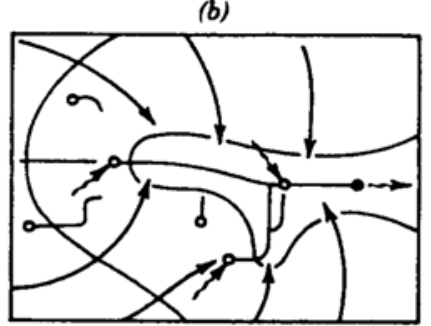

Mixed

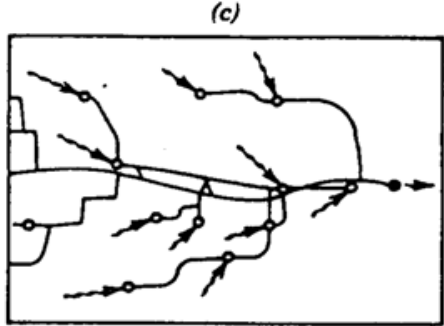

Conduit
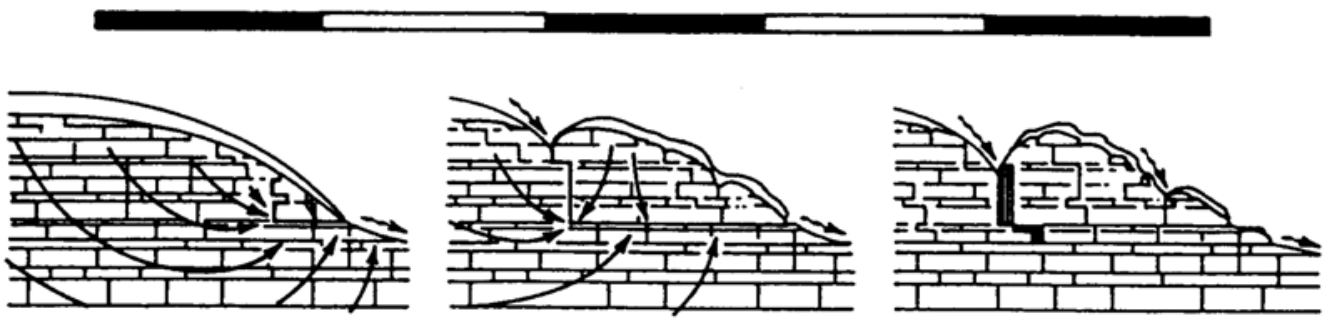

Gambar 2.3. Diffuse, campuran dan conduit airtanah karst (Domenico and Schwartz, 1990) 


\section{Perbedaan Utama Akuifer Karst dan Akuifer Non-karst}

Dalam geohidrolika akuifer, terdapat beberapa istilah sifat akuifer yaitu zonasi vertikal airtanah, porositas batuan, konduktivitas hidraulik $(K), \quad$ transmissivitas $(T)$, homogenitasheterogenitas, isotropi-anisotropi, dll. Sub bab ini akan membahas perbedaan utama karakteristik dan sifat-sifat akuifer pada daerah non-karst dan karst.

\section{a. Zonasi vertikal}

Pada akuifer non karst, zonasi vertikal mempunyai pola sebagai berikut :

- lapisan paling atas dibawah tanah adalah zona tak jenuh (aerasi)

- lapisan ditengah adalah zona intermediate yang dibagi lagi menjadi zone vadose dan zone kapiler

- lapisan di bawah muka airtanah (water table) dikenal sebagai zone jenuh air

Sifat dan kedudukan akuifer non-karst secara vertikal ini cenderung tetap dan hanya berfluktuasi menurut musim sepanjang tahun.

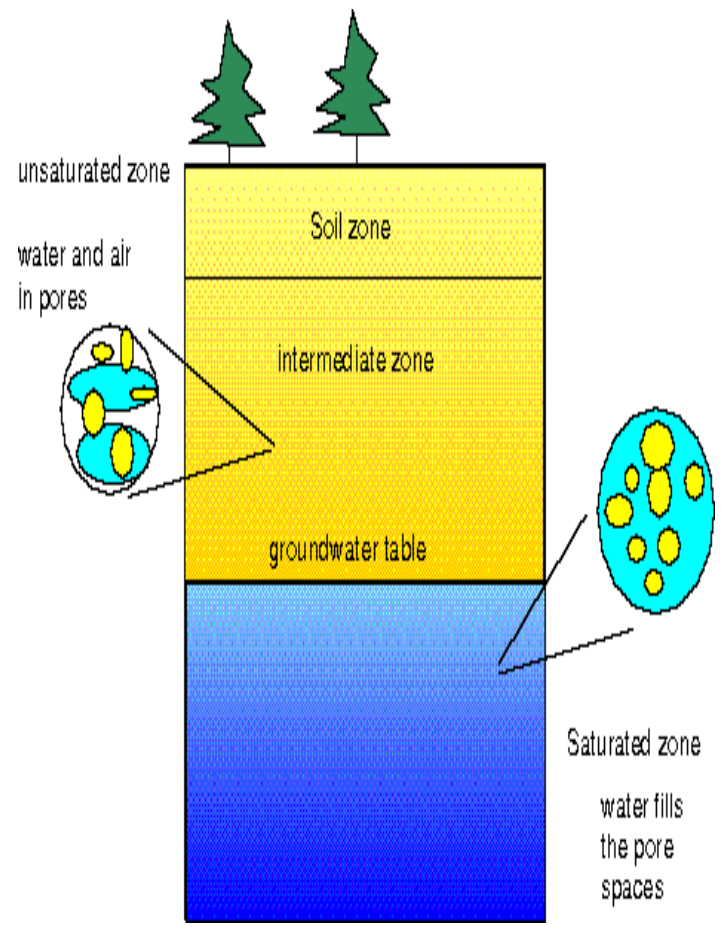

Sementara itu, sifat agihan vertikal akuifer pada batuan karbonat cenderung berubah dari waktu ke waktu tergantung dari cepat lambatnya tingkat pelarutan dan lorong-lorong yang terbentuk. Pada akhirnya, penurunan muka airtanah akan stabil setelah mencapai kedudukan yang sama dengan water level setempat (local base level) jika batuan karbonat terletak di atas formasi batuan lain. Secara umum perbedaan zonasi vertikal akuifer karst dan non karst disajikan pada Gambar 2.4.

\section{b. Porositas}

Porositas $(\alpha)$ atau kesarangan batuan adalah rasio antara volume pori-pori batuan dengan total volume batuan, seperti yang dinotasikan pada rumus ini :

$$
\alpha=\frac{\mathbf{V}_{\text {pori }}}{\mathbf{V}_{\text {tot }}}
$$

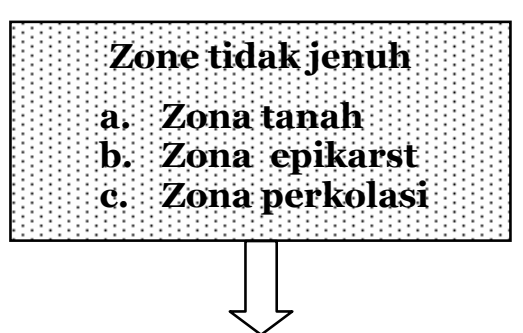

Gambar 2.4. Zonasi vertikal akuifer karst (kanan) dan non karst (kiri) 
Besar kecilnya porositas tergantung dari jenis batuan dan matrik pada batuan itu sendiri. Berbicara mengenai besarnya porositas batuan karbonat pada daerah karst tidak semata-mata tergantung dari matriks batuan, tetapi lebih tergantung dari proses lanjutan setelah batuan itu terbentuk atau muncul di permukaan bumi. Secara umum porositas batuan dibedakan menjadi dua tipe yaitu:

- Porositas primer, yaitu porositas yang tergantung dari matriks batuan itu sendiri; dan

- Porositas sekunder, yaitu porositas yang lebih tergantung pada proses sekunder seperti adanya rekahan ataupun lorong hasil proses solusional

Dalam hal ini, jika dikatakan bahwa batuan karbonat di daerah karst mempunyai porositas yang besar adalah lebih signifikan karena adanya percelahan hasil proses pelarutan sehingga lebih cocok digolongkan sebagai porositas sekunder. Kesimpulannya, batuan gamping yang belum terkarstifikasi akan mempunyai nilai porositas yang jauh lebih kecil dibandingkan dengan batuan gamping yang telah terkarstifikasi dengan baik. Tabel 2.1 menyajikan porositas pada beberapa jenis batuan termasuk pada batuan gamping/karbonat.

Batuan gamping dan juga dolomit yang belum terkarstifikasi mempunyai kisaran nilai porositas yang sangat kecil (maksimal 10\%). Sebaliknya, jika jika batuan gamping telah terkarstifikasi akan mempunyai nilai porositas yang tinggi (mencapai 50\%)

Selanjutnya, Gambar 2.5 mengilustrasikan perbedaan tipe porositas pada daerah karst dan non-karst.

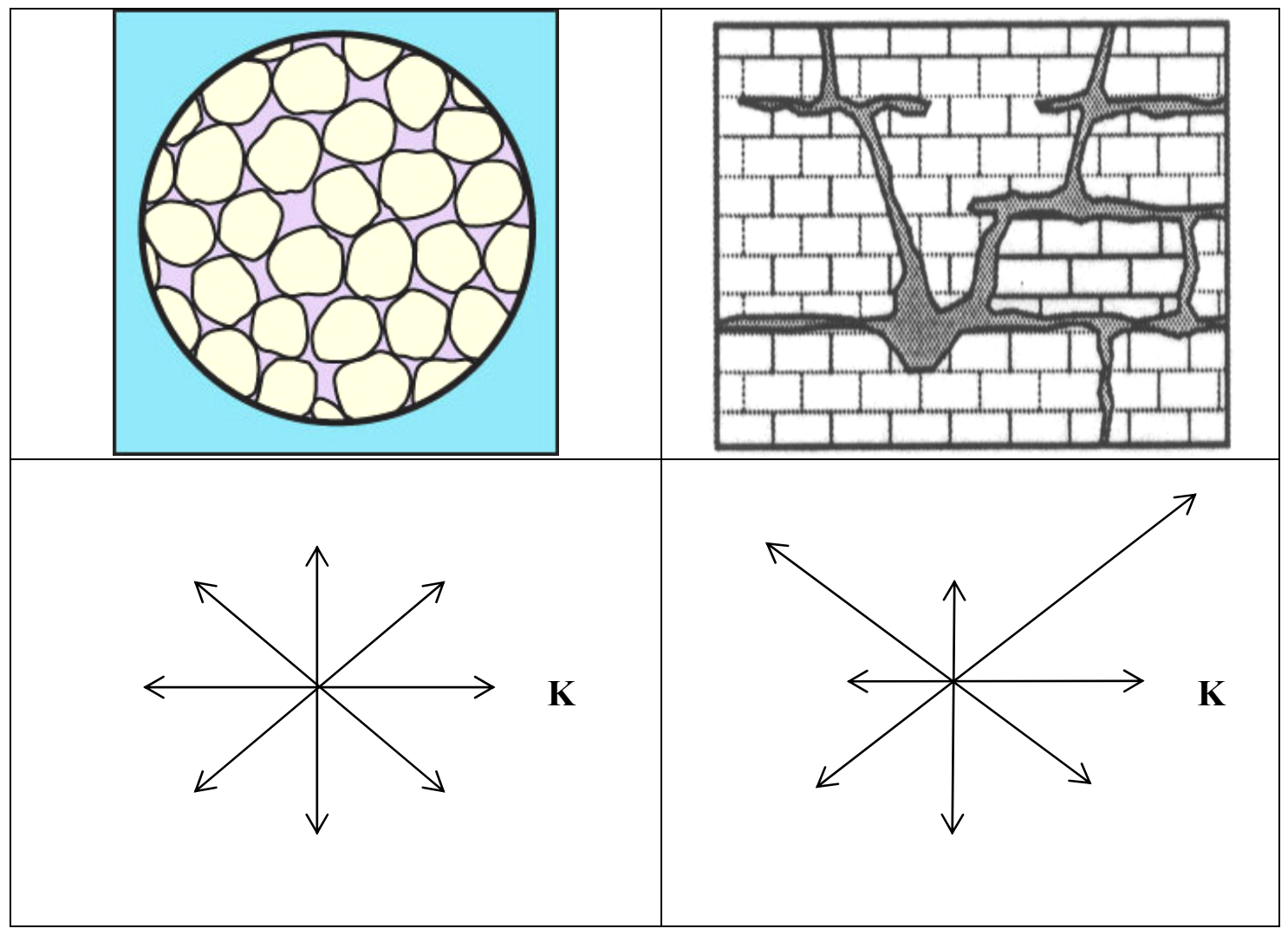

Gambar 2.5. Tipe porositas pada karst (kanan) dan non-karst (kiri) 
Tabel 2.1. Besarnya porositas pada berbagai material batuan

\begin{tabular}{|c|c|}
\hline Material & $\alpha(\%)$ \\
\hline \multicolumn{2}{|c|}{ Sedimen tidak kompak } \\
\hline Kerikil & $25-40$ \\
\hline Sand & $25-50$ \\
\hline Silt & $35-50$ \\
\hline Lempung & $40-70$ \\
\hline \multicolumn{2}{|c|}{ Batuan } \\
\hline Fractured basalt & $5-50$ \\
\hline Gamping terkarstifikasi & $5-50$ \\
\hline Sandstone & $5-30$ \\
\hline Gamping, dolomit & $0-20$ \\
\hline Shale & $0-10$ \\
\hline Fractured crystalline rock & $0-10$ \\
\hline Dense crystalline rock & $0-5$ \\
\hline
\end{tabular}

Sumber : Acworth (2001)

Dari Gambar 2.5 terlihat bahwa tipe porositas pada batuan non-karst biasanya bersifat teratur dan intergranuler (saling berhubungan ke segala arah), sementara pada batuan karst sangat tergantung dari arah dan kedudukan percelahan (cavities) yang terbentuk karena proses solusional. Dari waktu ke waktu, jika sistem percelahan masih memungkinkan untuk terus berkembang, maka besarnya porositas sekunder ini juga akan bertambah besar.

\section{c. Permeabilitas (K) dan Transmissivitas (T) akuifer}

Permeabilitas atau konduktivitas hidraulik (K) secara sederhana dapat diartikan sebagai kemampuan suatu batuan untuk meloloskan air/cairan. Nilai $\mathrm{K}$ tergantung dari media (batuan) dan independen terhadap jenis cairan. Sementara itu transmissivitas $(T)$ adalah sejumlah air yang dapat mengalir melewati satu unit luas akuifer secara $100 \%$ horizontal. Nilai T ini merupakan suatu fungsi berbanding lurus dengan $\mathrm{H}$ konduktivitas hidraulik (K) dan tebal akuifer (b), sehingga :

$$
\mathbf{T}=\mathbf{K} \cdot \mathbf{b}
$$

$$
\begin{aligned}
& \text { dimana } T=\text { transmissivitas akuifer }\left(\mathrm{m}^{2} /\right. \text { hari) } \\
& \mathrm{K}=\text { permeabilitas akuifer ( } \mathrm{m} / \mathrm{hari}) \\
& \mathrm{b}=\text { tebal akuifer }(\mathrm{m})
\end{aligned}
$$

Nilai $\mathrm{K}$ dan $\mathrm{T}$ tentu saja tergantung dari besar kecilnya porositas, sortasi batuan, tektur batuan, dll. Akibatnya, karena lorong-lorong solusional yang dihasilkan pada batuan gamping yang terkarstifikasi dengan baik mengakibatkan nilainya menjadi cukup signifikan pula dibanding jenis batuan lain, seperti yang ditampilkan pada Tabel 2.2.

Tabel 2.2 Besarnya porositas pada berbagai material batuan

\begin{tabular}{|l|r|r|}
\hline \multicolumn{1}{|c|}{ Hydraulic Conductivity (K) } & From (m/dt) & \multicolumn{1}{c|}{ To (m/dt) } \\
\hline Gravel & $10^{-3}$ & 1 \\
Clean sand & $10^{-5}$ & $10^{-2}$ \\
Silty sand & $10^{-7}$ & $10^{-3}$ \\
Silt,loess & $10^{-9}$ & $10^{-5}$ \\
Glacial till & $10^{-12}$ & $10^{-6}$ \\
Marine clay & $10^{-12}$ & $10^{-9}$ \\
Shale & $10^{-13}$ & $10^{-9}$ \\
Unfractured basement & $10^{-14}$ & $10^{-10}$ \\
Sandstone & $10^{-10}$ & $10^{-6}$ \\
Limestone & $10^{-9}$ & $10^{-6}$ \\
Fractured basement & $10^{-8}$ & $10^{-4}$ \\
Basalt (interflow) & $10^{-7}$ & $10^{-3}$ \\
Karst limestone & $10^{-6}$ & $10^{-3}$ \\
\hline
\end{tabular}

Sumber : Acworth (2001) 
Smith et. Al. (1976) dalam Ford and Williams (1989) mengevaluasi nilai $\mathrm{K}$ pada batuan gamping yang sangat masif memiliki permeabilitas primer yang pada mulanya sangat kecil, dan kemudian memiliki nilai $\mathrm{K}$ yang jauh lebih besar $\left(x 10^{6}\right)$ pada porositas sekunder batuan tersebut yang telah berkembang membentuk jaringan lorong bawah tanah yang baik.

\section{d. Isotropik dan homogenitas akuifer}

Pada batuan atau materi daerah non-karst yang tersortasi dengan baik, sebagai contoh akuifer lereng gunungapi yang didominasi oleh batuan pasir tentu saja mempunyai nilai $\mathrm{K}$ dan porositas yang teratur ke segala arah (Gambar 5). Pada kondisi ini nilai K (konduktivitas hidraulik) dapat dikategorikan sebagai independen terhadap posisinya pada perlapisan batuan. Akuifer ini dikenal sebagai akuifer yang homogen karena nilai $\mathrm{K}$ tidak tergantung posisinya pada suatu formasi batuan. Sebaliknya, jika nilai K bervariasi pada suatu titik pada formasi batuan, maka akuifernya dikenal sebagai heterogen.

Selanjutnya, dikenal pula istilah akuifer isotropis jika nilai $\mathrm{K}$ tidak tergantung dari arah pengukuran pada suatu formasi batuan dan akuifer anisotropis jika nilai $K$ tergantung/bervariasi tergantung kedudukan dan arah terhadap formasi batuan. Sebagai ilustrasi, tipe-tipe akuifer berdasarkan arah dan kedudukan nilai K dapat dilihat pada Gambar 2.6.

Pada akuifer karst yang didominasi oleh porositas sekunder yang arah dan dimensinya tergantung dari tingkat pelarutan batuan memiliki sifat heterogen-anisotropis. Pengukuran dan definisi tentang heterogenitas akuifer karst pertama kali dilakukan oleh Yuan (1985) dalam Ford and Williams (1989). Pengukuran yang dilakukan menunjukkan bahwa nilai $\mathrm{K}$ pada arah sumbu $x$, y dan $z$ tidak menunjukkan magnitudo yang sama, sehingga akuifer karst dapat diklasifikasikan sebagai anisotropis.

Sebagai kesimpulan, akuifer karst mempunyai perbedaan karakteristik yang sangat mencolok dibanding akuifer-akuifer yang lain, terutama karena sifat batuannya yang mudah larut dalam air dan membentuk lorong-lorong drainase. Sebenarnya, masih terdapat banyak sekali perbedaan, misalnya dalam hal muka airtanah (water table), aplikasi rumus aliran Darcy, dll., yang akan dibahas pada subbab berikutnya.

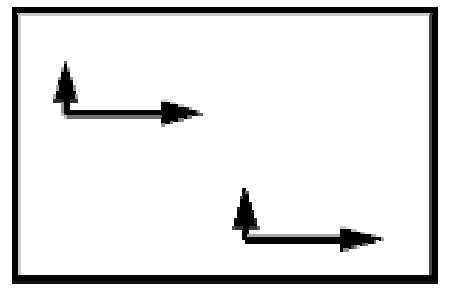

Homogeneous Anisotropic

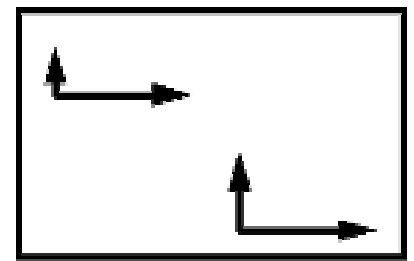

Heterogeneous Anisotropic

Leterogeneous Isorropic

Gambar 2.6. Akuifer homogen-heterogen, isotropis-anistropis (Sumber: http://www.bae.uky.edu/sworkman/AEN438G/aquifer/aquifer.html) 


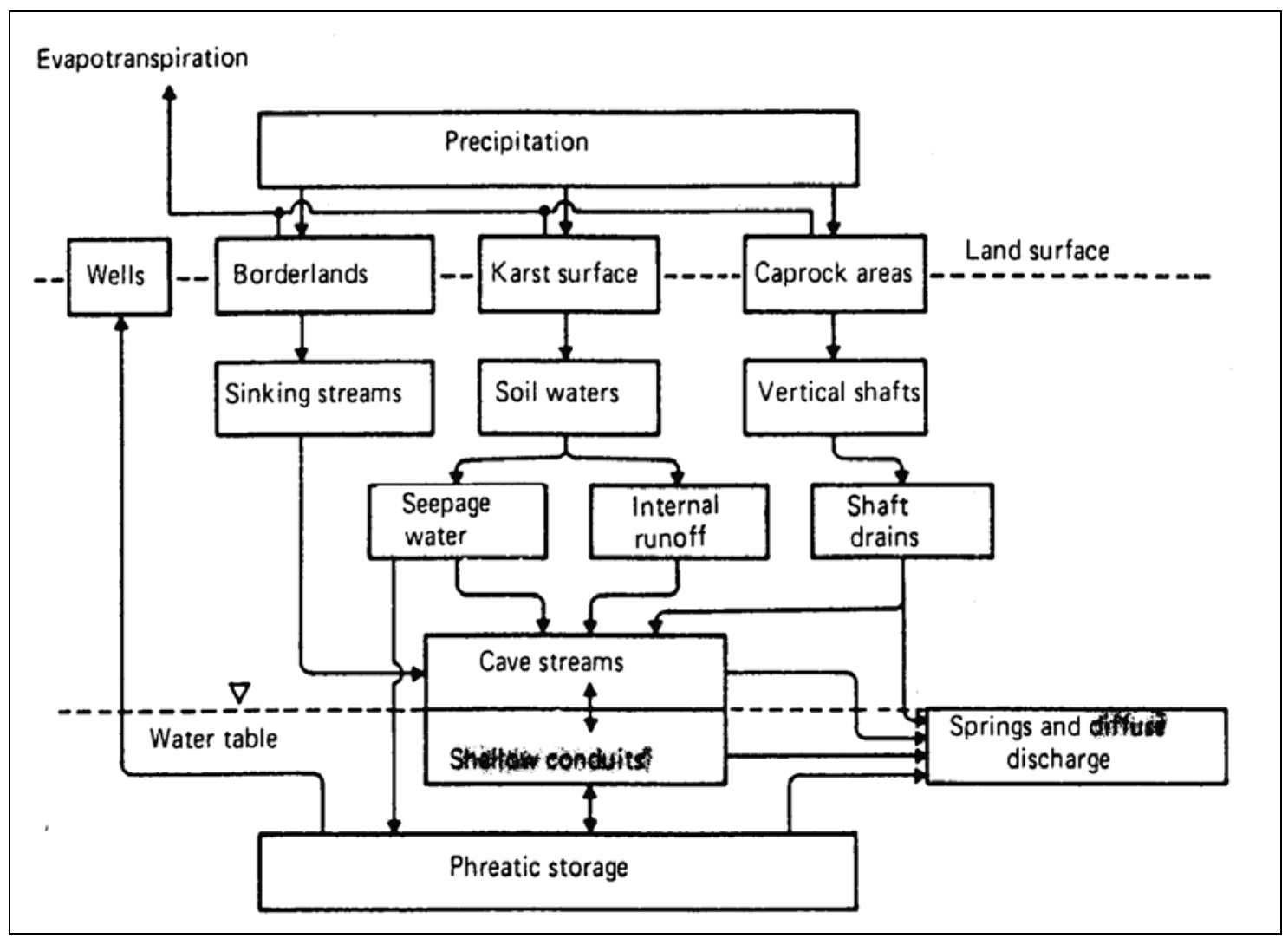

Gambar 2.7. Sistem aliran internal pada akuifer karst (White, 1988)

\section{Sistem Hidrologi Akuifer Karst}

Seperti dijelaskan pada Pendahuluan, sistem hidrologi di daerah karst didominasi oleh pola diffuse dan conduit. Selanjutnya Gambar 2.7 mengilustrasikan skema sistem aliran internal akuifer karst.

Pada Gambar 2.7 bagian atas adalah permukaan tanah, dan diasumsikan memiliki tiga komponen daerah tangkapan air yaitu: dari formasi karst itu sendiri, daerah lain non-karst yang berdekatan (contoh: aliran allogenic), dan masukan dari bagian atas formasi karst (misal: sungai yang masuk/tertelan) atau masukan langsung secara vertikal. Sebagian hujan akan terevapotranspirasikan dan sisanya akan masuk ke akuifer karst sebagai limpasan allogenic, limpasan internal dan infiltrasi rekahan-rekahan kecil (diffuse infiltration). Hujan yang masuk harus menjenuhkan tanah dan zone rekahan/epikarst sebelum masuk ke zona vadose. Sungai yang tertelan dan masuk melalui ponor pada lembah/doline biasanya langsung membentuk lorong conduit dan dapat berkembang sebagai saluran terbuka atau pipa-pipa vadose. Selain itu, air yang dialirkan dari dari daerah tangkapan hujan atau dari aquifer yang bertengger diatas formasi karst (jika ada) biasanya akan langsung menuju zone vadose melalui lorong-lorong vertikal. Akhirnya, aliran tersebut dapat bergabung dengan lorong conduit dari masukan lain, dan ada pula yang menjadi mataair bila kondisi topografi memungkinkan. Ilustrasi perkembangan conduit disajikan pada Gambar 2.8.

Imbuhan yang mempunyai sifat diffuse bergerak secara seragam kebawah melalui rekahan-rekahan yang tersedia (fissure). Jika sistem diffuse oleh fissure berkembang baik, maka dapat dipastikan bahwa proses infiltrasi pada zona epikarst berlangsung dengan baik. Pada karst 
yang berkembang baik, fissure sudah menjadi satu sistem dengan conduit (mixed-Gambar 2) dan memasok aliran airnya ke lorong-lorong conduit.
Gambar 2.9 menunjukkan perbedaan tipe aliran antara sistem diffuse dan conduit.
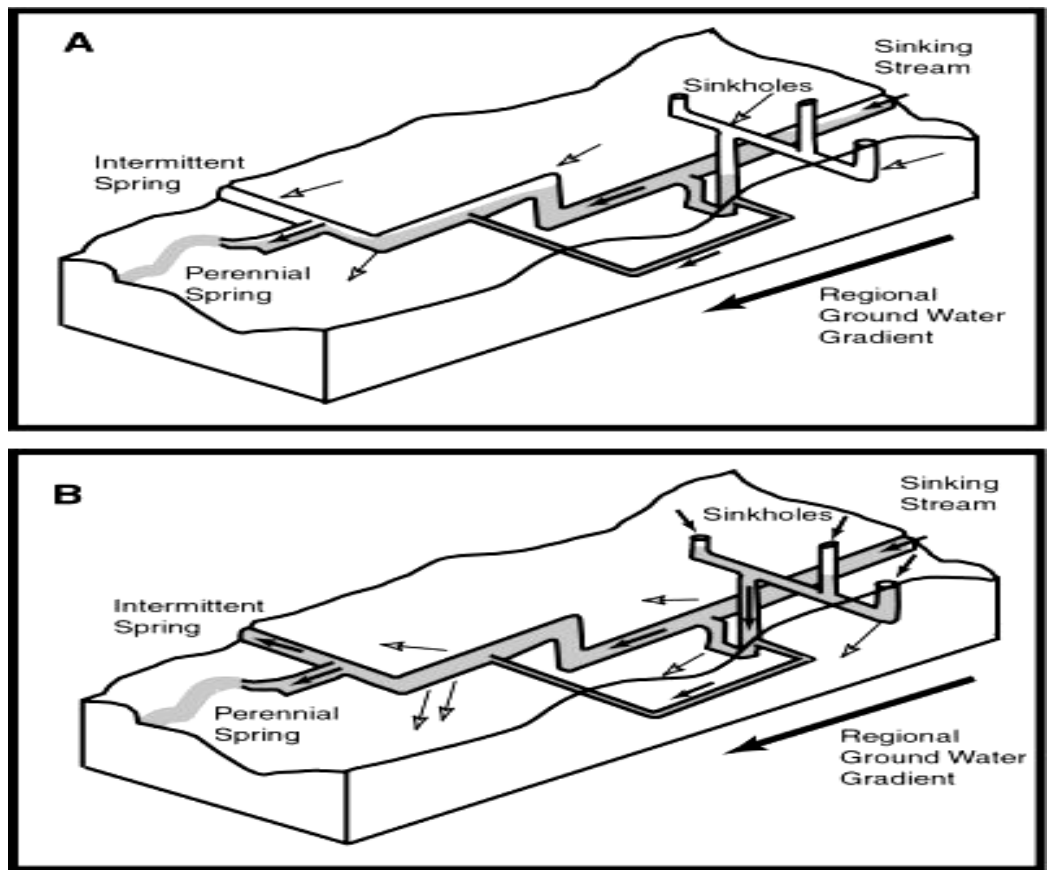

Gambar 2.8. Perkembangan lorong conduit (Sumber: water.usgs.gov/.../jbm_exchangematrix.htm)

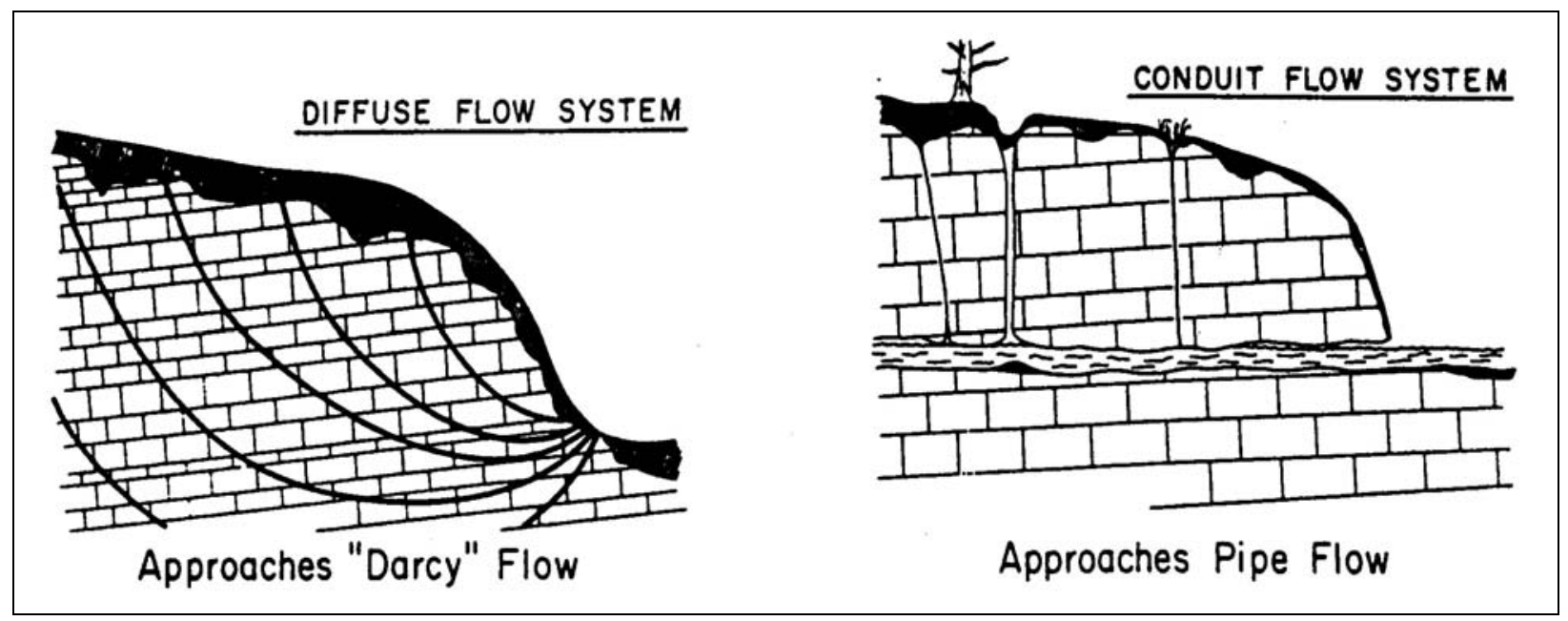

Gambar 2.9. Sistem aliran conduit vs sistem aliran diffuse (White, 1988) 
Jika kita perhatikan lagi Gambar 2.3, pada mulanya aliran yang bersifat diffuse lebih dominan melalui fissure/rekahan kecil yang berjumlah banyak dan rapat (Gambar 2.3.a). Dengan terus berkembangnya proses solusional, jaringan conduit (lorong/pipa) mulai berkembang dan menyebabkan meningkatnya jumlah aliran. Pada masa tersebut dapat dikatakan bahwa sistem aliran yang berkembang adalah campuran (mixed) antara sistem diffuse dan conduit (Gambar 2.3.b). Pada karst yang dewasa dan telah berkembang dengan baik sistem conduit lebih dominan dan hampir tidak terdapat sistem diffuse (Gambar 2.3.c). Selanjutnya, White (1988) membagi akuifer karst menjadi 3 model konseptual atas dasar sifat alirannya yaitu :

a. Diiffuse-flow karst aquifer atau akuifer dengan sistem aliran dominan diffuse. Akuifer ini tidak memiliki aktivitas pelarutan yang baik, sehingga dapat dikategorikan sebagai akuifer homogen dan sistem alirannya mendekati hukum Darcy (Gambar 9). Akuifer ini biasanya terdapat pada akuifer karbonat yang tidak mudah larut, misalnya dolomit. Air bergerak sepanjang rekahan-rekahan kecil yang hanya sedikit terpengaruh oleh aktivitas pelarutan. Jika terdapat goa, biasanya kecil dan tidak berhubungan satu sama lain. Output air biasanya juga hanya memiliki debit dalam jumlah yang kecil sebagai mataair atau rembesan. Muka airtanah dapat dengan mudah didefinisikan dan karena sebagian recharge adalah melalui fracture, fluktuasinya tidak terlalu besar dan kedudukan muka airtanah (water table) dapat sedikit diatas base level regional.

b. Free-flow karst aquifer. Akuifer ini juga memiliki aliran tipe diffuse, tetapi loronglorong solusional lebih dominan dimana sebagian besar aliran adalah melalui lorong-lorong conduit yang ada. Airtanah karst pada akuifer ini sangat terkontrol oleh distribusi dan arah dari lorong-lorong tersebut. Gambar 2.9. mengilustrasikan bahwa pendekatan hukum aliran yang digunakan adalah pipe flow karena sebagian besar air terdapat pada lorong- lorong conduit yang diibaratkan mempunyai bentuk seperti pipa dengan diameter tertentu. Oleh karena itu, kecepatan aliran diidentikkan dengan kecepatan aliran saluran permukaan (misal:sungai). Sifat alirannya adalah turbulen dan bukan laminar. Pada akuifer ini, mataair dapat mempunyai respon yang sangat cepat terhadap recharge/hujan dan mungkin pula mempunyai karakteristik hidrograf aliran yang sama dengan sungai permukaan.

c. Confined-flow karst aquifer atau akuifer karst yang berada dibawah batuan yang mempunyai nilai permeabilitas yang sangat kecil. Sistem aliran akuifer ini sangat dikontrol oleh lapisan diatasnya, walaupun memiliki lorong-lorong hasil proses solusional.

\section{Muka airtanah karst}

Muka airtanah adalah batas antara zone jenuh dan zone tak jenuh. Secara sederhana muka airtanah adalah air yanag kita temukan pertama kali ketika kita menggali sebuah sumur. Secara regional, notasi airtanah sering kali dinyatakan dengan suatu istilah yang dikenal sebagai hydraulic head atau jumlah antara tekanan hidrostatis airtanah dan ketinggian tempat. Lebih mudahnya, nilai hydraulic head adalah nilai ketinggian tempat dikurangi ketinggian muka airtanah dari permukaan bumi, seperti yang disajikan pada Gambar 2.10. Selanjutnya, peta garis yang menunjukkan tempat yang mempunyai nilai hydraulic head yang sama disebut peta kontur airtanah atau equipotential map. Jika peta tesebut dilengkapi dengan arah aliran airtanah maka dikenal sebagai flownets atau jaring-jaring airtanah. Karena airtanah mengalir dari tempat yang bernilai hydraulic head tinggi ke rendah, maka akan memiliki apa yang dikenal sebagai hydraulic gradient atau kemiringan muka airtanah.

Apakah ada muka airtanah (watertable) di akuifer karst? Dan jikalau ada apakah mempunyai karakteristik seperti halnya pada akuifer-akuifer non-karst?. Perdebatan mengenai karakteristik dan eksistensi muka airtanah di akuifer karst sudah berlangsung sejak puluhan tahun yang lalu. 


\section{Hydraulic head, $\mathbf{h}$}

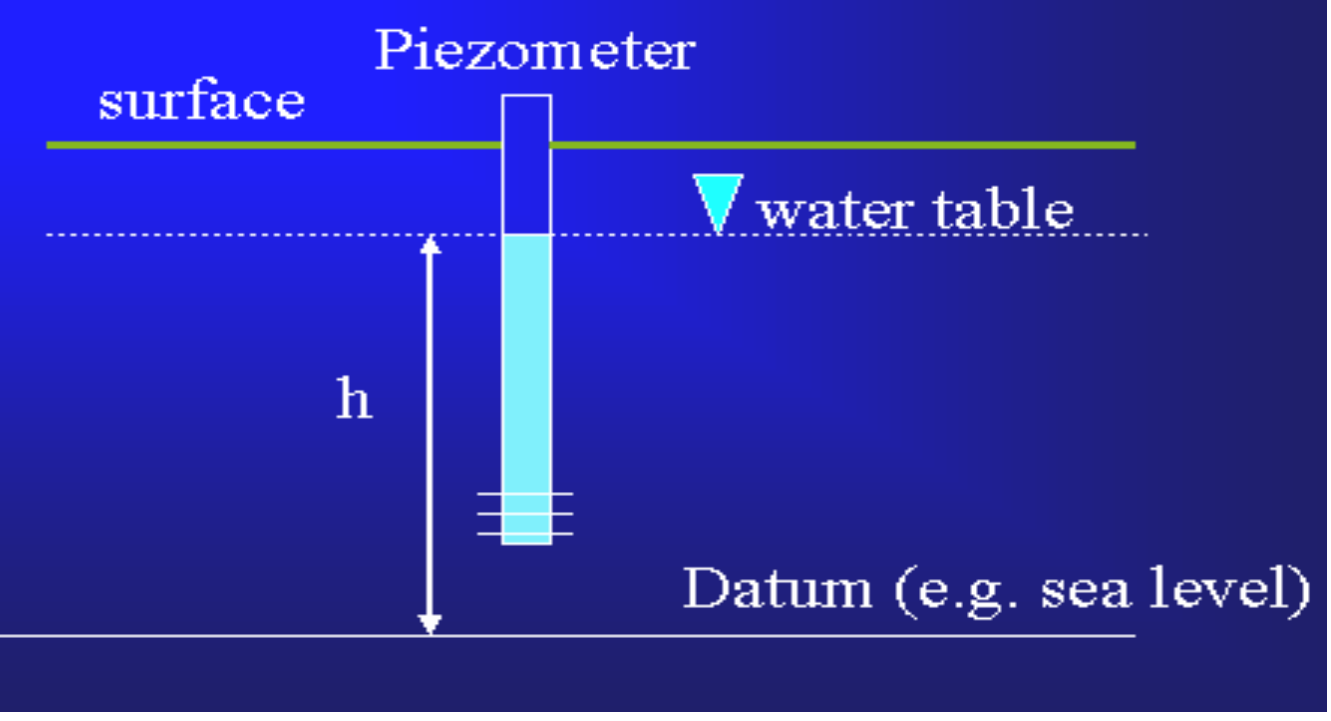

Gambar 2.10. Hydraulic head

Pada satu pihak banyak argumen percaya bahwa sungai yang masuk ke akuifer karst secara langsung/tertelan melalui swallow hole dan menjadi sungai bawah tanah dan mengalir terus ke bawah serta tidak mempunyai level atau muka freatik yang teratur/homogen seperti halnya pada akuifer non-karst, sehingga disimpulkan bahwa muka airtanah tidak dapat didefinisikan/tidak ada.

Pendapat lain mengatakan bahwa muka airtanah di akuifer karst dapat didefinisikan dengan cara melihat keseluruhan cekungan airtanah karst dan sekitarnya dan tidak hanya terfokus pada akuifer yang didominasi oleh sistem conduit saja. Cekungan karst ini akan mempunyai dua sistem aliran utama yaitu diffuse dan conduit, walupun pada tingkat yang lebih dalam akan lebih terkonsentrasi pada lorong-lorong conduit. Sebagai contoh adalah keberadaan goa-goa dengan sungai bawah tanah. Pada akhirnya, jika gerakan airtanah pada lorong conduit sudah mulai pelan, biasanya sudah mulai mendekati laut atau pantai sehingga kemiringan muka airtanahnya sudah mulai rendah dan mendekati datar. Pada kondisi ini, orang biasanya dapat membuat sumur gali untuk keperluan sehari-hari, sehingga dapat disimpulkan bahwa muka airtanah sudah dapat didefinisikan. Pada kondisi ini juga tidak begitu penting apakah air yang terdapat pada sumur itu merupakan muka airtanah atau merupakan lorong conduit yang jenuh air dan tepat pada pertemuan retakan-retakan batuan karbonat. Selanjutnya, ketinggian muka airtanah dapat didefinisikan dengan cara melakukan tracer test yang dikombinasikan dengan pemetaan goa, pemetaan retakan dan conduit, serta pemetaan muka airtanah pada sumur-sumur gali penduduk. Contoh yang sudah dilakukan di DIY adalah yang dilakukan oleh MacDonalds and partners (1983) ketika mencoba membuat peta kontur muka freatik pada karst Gunung Sewu di Kabupaten Gunung Kidul.

White (1988) menyatakan bahwa terjadinya silang pendapat mengenai ada tidaknya muka airtanah di karst lebih disebabkan oleh ketidakpersamaan atau kurangnya pengetahuan mengenai konsep muka airtanah. Muka airtanah tidak pernah statis dan berfluktuasi menurut faktorfaktor yang dapat mempengaruhinya seperti terhadap musim. Lebih jauh lagi, mendefiniskan muka airtanah karst memang tidak semudah 
mencari muka airtanah pada akuifer yang teratur, homogen dan isotropik. Keunikan akuifer karst adalah terletak pada respons yang cepat pada sistem aliran conduit jika terjadi perubahan imbuhan (hujan) dibandingkan pada sistem diffuse. Pada sistem conduit, muka airtanah akan cepat sekali naik mencapai puluhan meter hanya dalam waktu beberapa jam saja dan selanjutnya bisa langsung turun lagi dengan cepat. Kenyataan ini hampir tidak pernah dijumpai pada akuifer jenis lain, bahkan pada akuifer karst lain yang didominasi oleh aliran diffuse. Pada karst dengan aliran diffuse, yang tentu saja memiliki nilai konduktivitas hidraulik lebih kecil, respon terhadap hujan akan berjalan pelan, sehingga dapat dikatakan bahwa fungsi regulator karst berjalan dengan baik.

Pada sisi lain, stratigrafi pada cekungan dimana akuifer karst berada juga dapat berpengaruh terhadap sifat dan kedudukan muka airtanah karst (Fetter, 1994). Hal ini dapat juga terjadi pada akuifer berbatuan karbonat yang mempunyai tipe karbonat yang berbeda. Gambar 2.11. mengilustrasikan beberapa kondisi yang menyebabkan adanya perbedaan kemiringan muka airtanah pada akuifer karst.
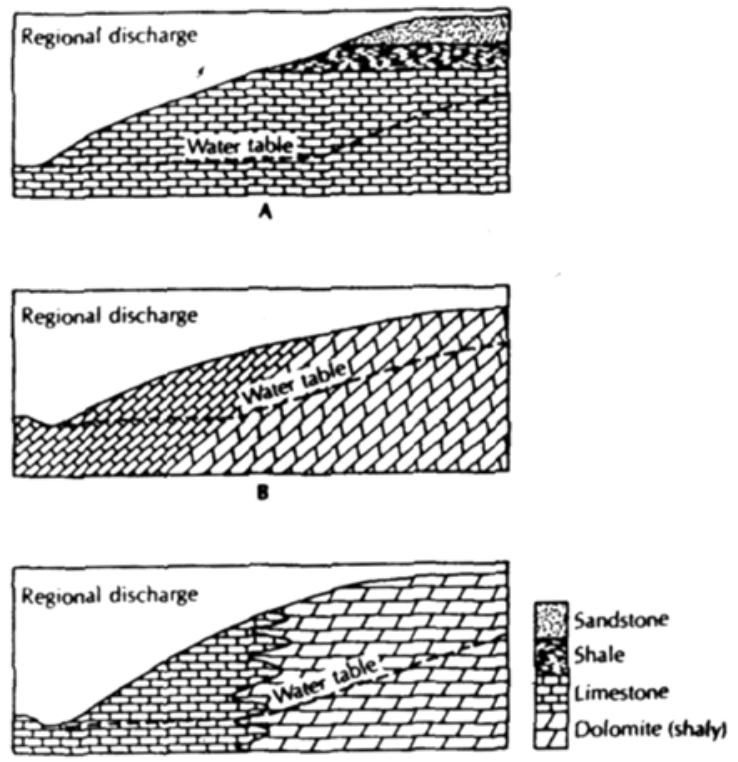

Gambar 2.11. Kondisi geologis yang berpengaruh terhadap muka airtanah (Fetter, 1994)
Keterangan dari Gambar 2.11 adalah sebagai berikut :

- Gambar A. Akuifer bagian atas adalah sandstone yang relatif mempunyai nilai $K$ yang cukup. Tetapi, karena dibawah formasi sandstone terdapat shale yang memiliki nilai $\mathrm{K}$ kecil dan menyebabkan terbatasnya imbuhan (recharge) ke formasi batuan gamping di lapisan paling bawah. Sebaliknya, pada akuifer bagian kiri recharge dari air hujan dapat mengalir secara bebas menuju batuan karbonat, sehingga proses solusional dapat belangsung secara lancar. Kesimpulannya, terdapat dua pola kemiringan muka airtanah pada bagian kiri dan kanan akibat adanya perbedaan stratigrafi.

- Gambar B dan C. Akuifer ini mempunyai perbedaan tingkat pelaruran (dolomit dan gamping yang mudah larut) yang mengakibatkan terjadinya perbedaan kemiringan muka airtanah.

Kesimpulan dari bahasan muka airtanah karst diatas adalah bahwa karakteristik muka airtanah di akuifer karst sangat berbeda dengan akuifer di tempat lain. Faktor yang sangat menentukan adalah adanya sifat akuifer karst yang cenderung anisotropis karena dominasi proses pelarutan yang menghasilkan lorong-lorong conduit yang sangat tidak beraturan. Karena sifatnya yang memiliki nilai konduktivitas hidraulic (K) sangat tinggi terutama pada area yang mempunyai perkembangan lorong conduit yang sangat baik, muka airtanah karst dapat berada sangat dalam di bawah permukaan tanah. Selain itu, karena sifatnya tersebut, kadang-kadang terdapat genangan air/aliran yang bertengger pada suatu cekungan atau lorong diatas muka airtanah. Hal inilah yang sering menyebabkan sulitnya mendefiniskan muka airtanah di akuifer karst. Akhirnya, karena proses pelarutan sangat dikontrol oleh adanya retakan/rekahan pada batuan karbonat, maka muka airtanah dapat tidak bersambung satu sama lain (discontinuous) walaupun pada tempat-tempat yang sudah dekat dengan laut dan memiliki gradient hidraulik sangat 
rendah, muka airtanah karst dikontrol oleh muka airtanah dasar (base level) baik itu lokal maupun dan regional. Sebagai contoh, jika kita mengebor atau membuat sumur di akuifer karst, jangan heran jika pada kedalaman tertentu kita memperoleh air, tetapi pada lokasi lain yang berdekatan dengan kedalaman yang sama kita tidak dapat menemukan air.

\section{Hukum Aliran di Akuifer Karst}

Hukum Darcy dikenal secara luas di kalangan ahli hidrologi dan biasa digunakan untuk menentukan debit airtanah. Dalam percobaannya (Gambar 2.12) yang mengumpamakan akuifer sebagai suatu tabung yang berisi pasir, Darcy menemukan bahwa kecepatan airtanah berbanding lurus dengan beda tinggi (head) antara dua titik dalam tabung dibagi dengan panjang tabung yang kita kenal sebagai kemiringan airtanah, dan juga berbanding lurus terhadap koefisien yang kita kenal sebagai nilai konduktivitas hidraulik (K). Sehingga untuk menghitung debit airtanah tinggal kita kalikan dengan luas penampang tabung.

Jika kita notasikan maka Hukum Darcy adalah sebagai berikut:

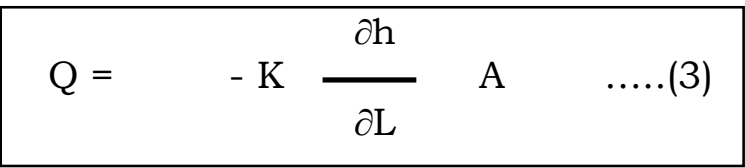

dimana :

A = luas penampang tabung ( akuifer)

$\mathrm{K}=$ konduktivitas hidraulik

$\partial \mathrm{h} / \partial \mathrm{L}=$ kemiringan muka airtanah

Apakah hukum Darcy bisa diterapkan di akuifer karst?. Beberapa hal sudah disinggung pada Gambar 9 bahwa jika tipe aliran yang dominan adalah conduit dan pipa-pipa hasil pelarutan sudah berkembang baik, maka pendekatan Darcy ini sudah tidak dapat lagi dipergunakan lagi di akuifer karst. Selain itu, hukum Darcy mempunyai beberapa keterbatasanketerbatasan pada kondisi sebagai berikut:

a. Kemiringan muka airtanah sangat kecil, misal pada cekungan yang sangat besar, relatif datar, airtanah tidak mengalir

b. Kecepatan aliran sangat tinggi, kemiringan muka airtanah sangat tinggi, dan tipe aliran turbulent

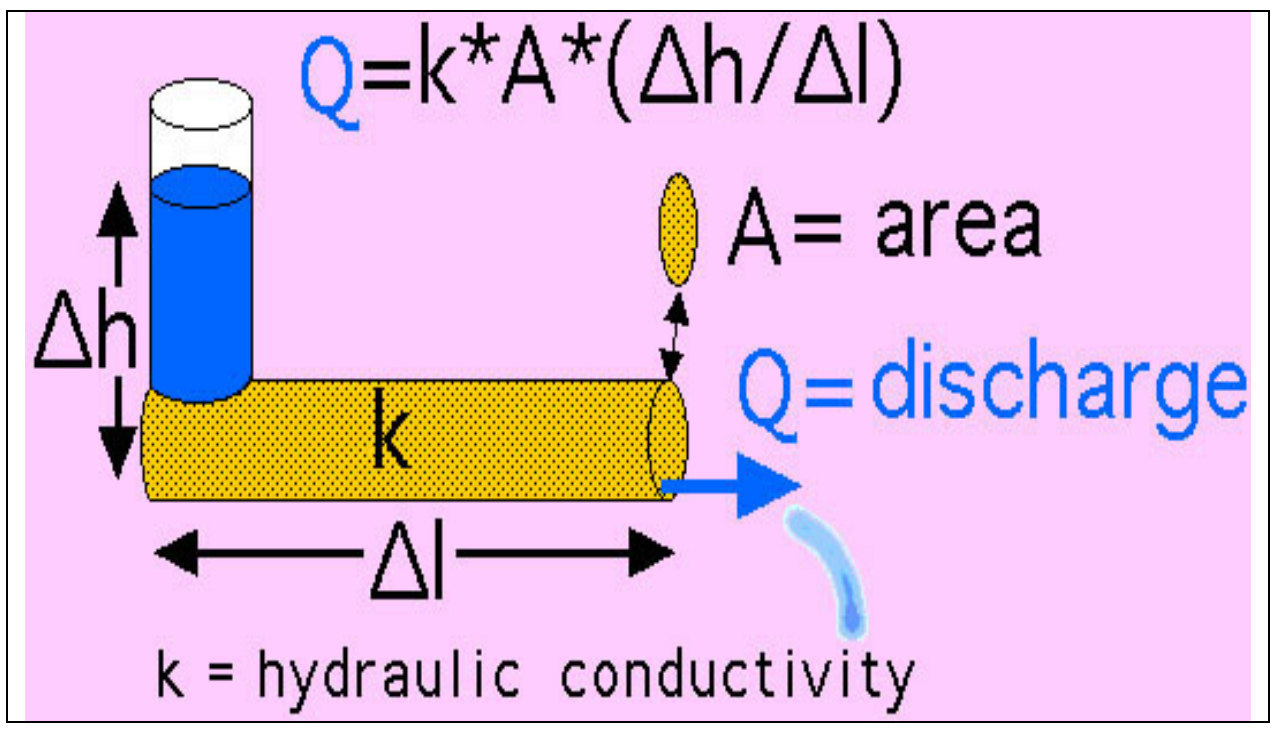

Gambar 2.12. Percobaan Darcy 
Pada akuifer karst yang sudah berkembang baik, adanya conduit dan pipa-pipa solusional dapat mengakibatkan kecepatan aliran yang sangat tinggi dan tipe alirannya bukan laminar tetapi turbulent. Untuk memudahkan dan menguji coba apakah hukum Darcy masih dapat berlaku pada suatu akuifer karst maka dapat digunakan formula Reynolds Number (Re). Jika Re antara 1 s.d. 10, maka hukum Darcy masih dapat digunakan

$$
\operatorname{Re}=\rho \vee d / \mu \quad \ldots \ldots . . . .(4)
$$

$$
\text { Dimana : } \quad \begin{array}{ll}
\rho & =\text { kerapatan cairan } \\
\mu & =\text { viskositas/kekentalan } \\
& d=\text { panjang segmen } \\
& v=\text { kecepatan }
\end{array}
$$

Bear (1972) dalam Ford and Williams (1992) menyimpulakan bahwa aliran turbulent secara mutlak belum akan terjadi jika kecepatan aliran belum terlalu tinggi dan nilai $\mathrm{Re}$ masih berkisar antara $100-1000$. Kisaran ini dapat dikatakan sebagai batas antara tipe aliran turbulent dan laminar. Selanjutnya Gambar 2.13 menyajikan hubungan antara diameter lorong conduit, kecepatan aliran dan nilai Re.

Selain itu, Ford and Williams (1992) mengatakan bahwa debit airtanah pada percobaan Darcy diukur pada cross section penampang luas pada media jenuh, dalam hal ini pasir. Sedangkan, pada akuifer karst yang mempunyai sifat heterogen-anisotropis, maka kecepatan aliran akan berbeda-beda jika kita umpamakan akuifer itu sebagai suatu tabung. Pada kondisi ini, maka kecepatan air mengalir akan sangat tergantung dari distribusi retakan atau percelahan pada akuifer karst, sehingga secara mikroskopis pasti mempunyai debit yang lebih besar dibanding jika kita pandang seluruh tabung sesuai hukum Darcy tersebut. Beberapa peneliti seperti Bocker (1973) dalam Ford and Williams (1992) menyimpulkan bahwa Hukum Darcy tidak dapat dipakai jika terdapat retakan pada akuifer karst dengan diameter lebih dari $3 \mathrm{~mm}$ pada kondisi kemiringan muka airtanah lebih dari 0,01. Selanjutnya Ewers (1982) dalam Ford and Williams (1992) bahkan menyatakan jika diameter dari conduit sudah mencapai $1 \mathrm{~mm}$ maka aplikasi dari hukum Darcy sangat diragukan. Selanjutnya, Ford and Williams (1992) menyatakan bahwa rumus Darcy dengan sedikit perubahan yang belakangan dikenal sebagai rumus DarcyWeisbach dapat digunakan pada kondisi akuifer yang didominasi oleh conduit dan mempunyai tipe aliran turbulent.

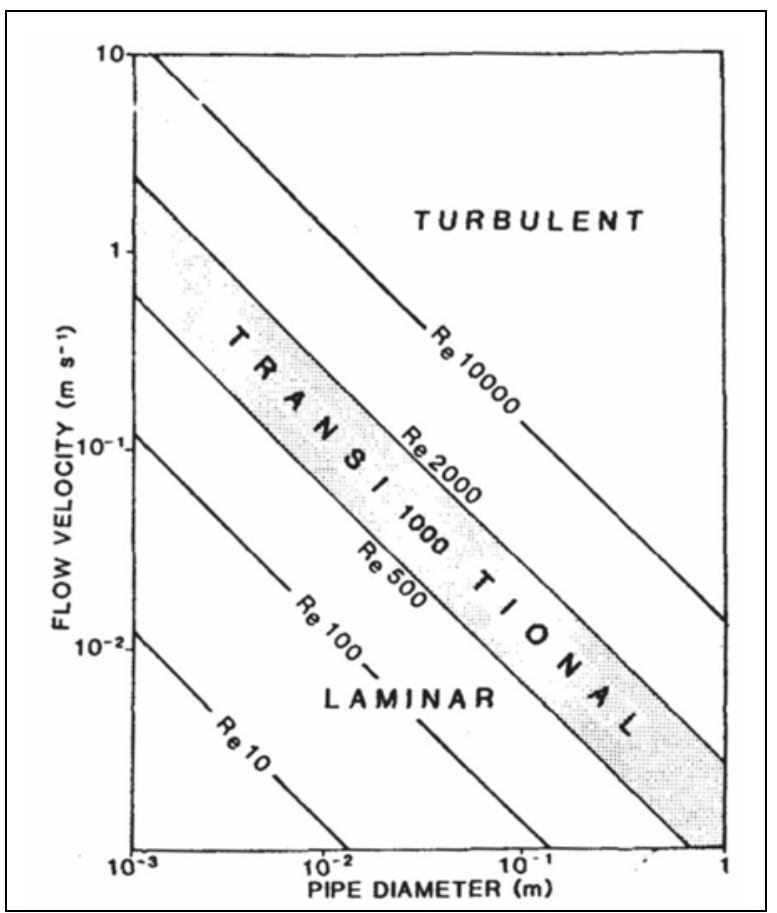

Gambar 2.13. Nilai Re pada berbagai kecepatan aliran dan diameter pipa (Smith et.al, 1976 dalam Ford and Williams, 1992)

\section{Imbangan Air di Akuifer Karst}

Pada suatu DAS, siklus hidrologi dan imbangan air dapat diketahui dengan cara mengetahui komponen-komponen utama penyumbang air. Hujan yang jatuh di DAS dapat dianggap sebagai input utama, dan muara sungai dapat didefinisikan sebagai suatu output. Di dalam DAS, jumlah air yang masuk dan keluar haruslah sama. Hujan yang jatuh ke permukaan tanah terbagi menjadi tiga sub sistem aliran yaitu (a) 
aliran yang terinfiltrasikan pada zona tanah dan terperkolasikan menuju muka airtanah, (b) aliran permukaan (overland flow) yang kemudian berkembang menjadi sungai permukaan, dan (c) air yang kembali ke atmosfer melalui evaporasi dan transpirasi. Imbangan air secara umum dapat dirumuskan sebagai berikut :

$$
\begin{array}{ll}
\mathrm{P}-\mathrm{E}=\mathrm{I}+\mathrm{R} & \ldots \ldots \ldots \ldots \ldots \ldots \ldots \\
\text { dimana : } & \mathrm{P}=\text { hujan } \\
& \mathrm{E}=\text { evapotranspirasi } \\
& \mathrm{I}=\text { infiltrasi } \\
& \mathrm{R}=\text { aliran permukaan }
\end{array}
$$

Secara khusus, imbangan air di karst mempunyai komponen-komponen seperti yang akan dijelaskan berikut ini. Aliran permukaan dari daerah non-karst seperti sungai permukaan masuk ke akuifer karst melalui ponor $\left(\mathbf{Q}_{\mathrm{a}}\right)$ dan ada pula yang tetap sebagai sungai permukaan $\left(\mathbf{Q}_{R}\right)$. Air hujan yang terinfiltrasi menembus lapisan tanah karst sebagai diffuse infiltration melalui rekahan dan retakan diberi notasi $\mathbf{Q}_{\mathbf{d}}$. Sisa dari hujan dikurangi infiltrasi yang akhirnya menjadi runoff akhirnya juga masuk ke lobang-lobang ponor/sinkholes dikenal sebagai runoff internal $\left(Q_{1}\right)$. Komponen aliran permukaan dan bawah permukaan yang bergabung di akuifer karst menjadi keluaran baik itu melalui mata air atau resurgence di laut $\left(\mathbf{Q}_{\mathrm{B}}\right)$. Secara total, imbangan air karst dapat didefinisikan sebagai berikut :

$$
Q_{\text {in }}-Q_{\text {out }}=Q s
$$

dimana :

$Q_{\text {in }}=$ input komponen air yang masuk ke karst

$Q_{\text {out }}=$ keluaran (outlet) pada periode yang sama

Qs = perubahan simpanan

Selanjutnya, Gambar 2.14 menampilkan skema imbangan air yang terdapat pada cekungan karst.
Dari skema tersebut dapat dijelaskan bahwa jika hujan puncak terjadi, maka muka airtanah akan naik, demikian juga dengan simpanan pada akuifer karst. Pada musim kemarau, karena recharge dari hujan berkurang maka simpanan juga akan turun. $Q_{s}$ dapat bernotasi negatif jika jumlah masukan lebih kecil dari output, dan sebaliknya $Q_{s}$ bernotasi positif jika input lebih besar dari output. Jika kita beranggapan bahwa akuifer karst hanya memiliki satu output, maka $Q_{B}$ atau total keluaran pada mata air dapat dinotasikan sebagai berikut :

$$
Q_{B}=Q_{a}+Q_{1}+Q_{d}+Q_{R}-Q_{s} \ldots(7)
$$

Dimana :

$$
\begin{array}{ll}
Q_{B} & =\text { total output } \\
Q_{a} & =\text { aliran permukaan non-karst (allogenic) } \\
Q_{1} & =\text { run-off dari internal karst } \\
Q_{d} & =\text { infiltrasi yang bersifat diffuse } \\
Q_{R} & =\text { sungai permukaan } \\
Q_{S} & =\text { simpanan di akuifer }
\end{array}
$$

Rumus ini biasanya dapat diterapkan pada akuifer karst secara umum, dan jika selama beberapa waktu penerapan, imbangan air mendekati nol berarti akuifer karst memiliki sistem conduit yang sudah berkembang. Sebaliknya jika imbangan air tidak = nol, maka dapat disimpulkan bahwa terdapat komponen masukan atau keluaran yang tidak diketahui secara pasti jalurnya.

\section{SURVEY HIDROLOGI DI KARST}

$\begin{array}{cccc}\begin{array}{c}\text { Seperti } \\ \text { sebelumnya, }\end{array} & \begin{array}{c}\text { dijelaskan } \\ \text { proses }\end{array} & \begin{array}{c}\text { pada } \\ \text { solusional }\end{array} & \begin{array}{r}\text { bahasan } \\ \text { yang }\end{array}\end{array}$ menyebabkan adanya perbedaan perkembangan (karstifikasi) pada akuifer karst menyebabkan pola akuifer yang terbentuk bersifat heterogenanisotropis. Akibatnya evaluasi mengenai struktur dan sifat dari akuifer karst merupakan permasalahan tersendiri dan mensyaratkan teknik yang berbeda untuk dilakukan penelitian. Penelitian terpenting di kawasan karst adalah untuk mengevalusi keberadaan sumber daya air termasuk distribusi spasial, kuantitas dan 
kualitasnya. Secara umum karena karakteristiknya yang khas, akuifer karst menimbulkan banyak masalah dalam hal penentuan dan penyelidikan sumberdaya air karst yang terdapat pada loronglorong conduit dan terakumulasi pada sungaisungai bawah tanah. Selain itu, tidak mungkin kita dapat melakukan generalisasi seperti yang dilaukan pada akuifer lain karena karst dapat memiliki berbagai tipe dan karakter akuifer yang berbeda-beda pada suatu daerah (Ford and Williams, 1992). Selanjutnya, keberadaan air di karst biasanya hanya dapat diamati pada sungai bawah tanah dan mata air yang dapat keluar di laut ataupun pada goa serta karena adanya faktor topografi tertentu. Akibatnya, kemampuan untuk melakukan survey bawah permukaan mutlak dipunyai oleh peneliti hidrologi karst.
Ford and Williams (1992) mengemukakan bahwa penelitian mengenai sistem aliran bawah permukaan karst perlu mencermati hal-hal seperti berikut ini:

- distibusi vertikal dan horisontal dari akuifer

- batas akuifer

- sifat aliran masuk dan keluar akuifer karst

- hubungan, sistem pergoaan dan pola drainase bawah permukaan

- karakteristik fisik akuifer

- respon terhadap imbuhan (recharge) pada berbagai kondisi akuifer

- hubungan aliran input dan output

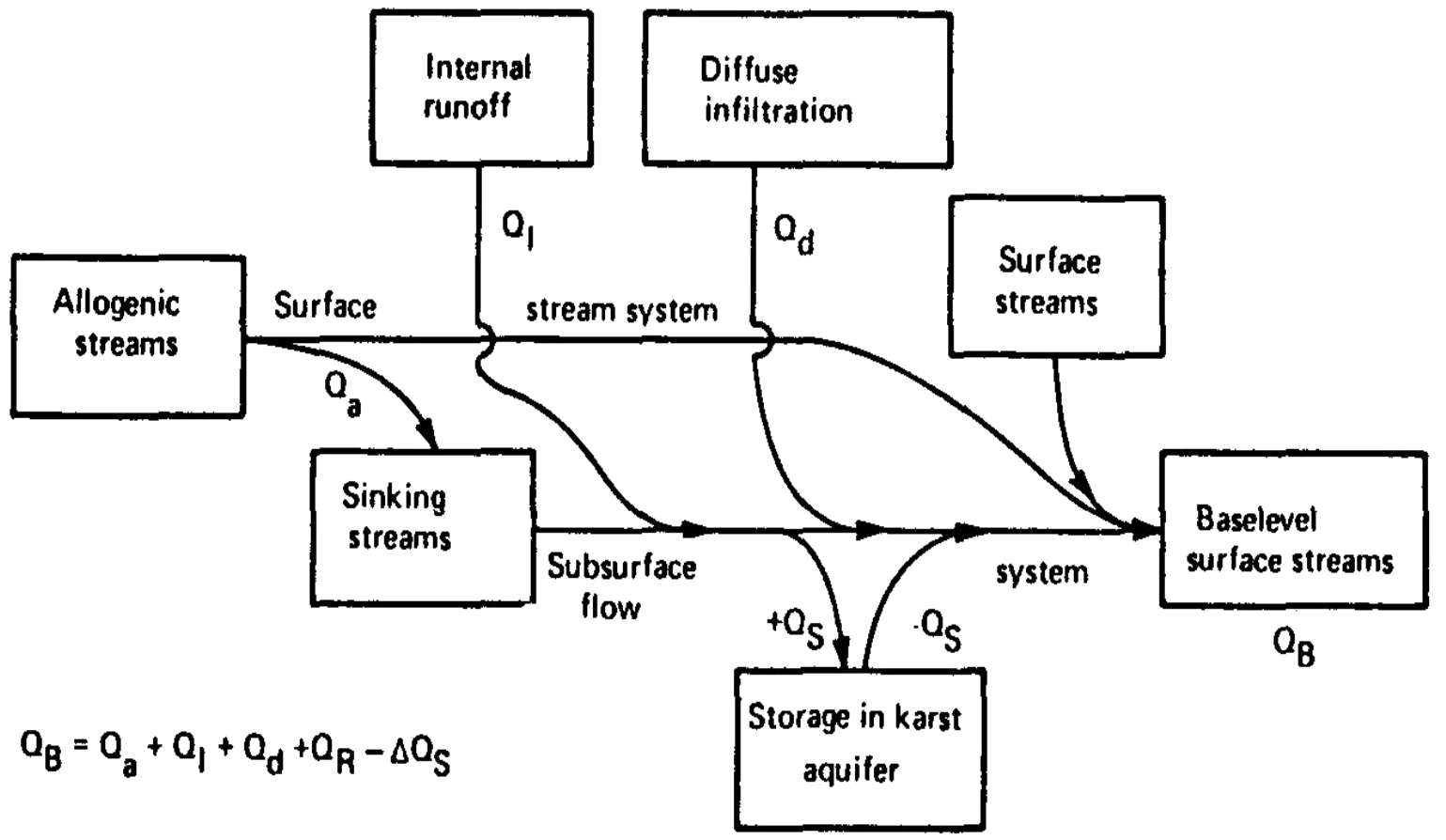

Gambar 2.14. Imbangan air pada cekungan fluviokarst (White, 1988) 
Tabel 2.3. Metode-metode evaluasi sistem drainase karst

\begin{tabular}{|c|c|c|c|c|}
\hline Kondisi aliran & Batas akuifer & $\begin{array}{c}\text { Karakteristik } \\
\text { akuifer }\end{array}$ & Skala & Cara analisis \\
\hline $\begin{array}{l}\text { Laminar-linier } \\
\text { (diffuse-darcian) }\end{array}$ & infinite & Bebas/tertekan & spesifik & Lobang bor \\
\hline $\begin{array}{l}\text { Laminar-linier } \\
\text { (diffuse-darcian) }\end{array}$ & Kedap/bocor & $\begin{array}{l}\text { Konstan, } \\
\text { tergantung } \\
\text { ketebalan }\end{array}$ & lokal & $\begin{array}{l}\text { Uji pompa, korelasi } \\
\text { input-output }\end{array}$ \\
\hline $\begin{array}{l}\text { Mixed laminar- } \\
\text { turbulent }\end{array}$ & $\begin{array}{l}\text { Homogen horizontal } \\
\text { Heterogen vertikal }\end{array}$ & Homogen-heterogen & $\begin{array}{l}\text { regional } \\
\text { cekungan karst }\end{array}$ & $\begin{array}{l}\text { Imbangan air } \\
\text { Hidrograf mataair } \\
\text { Kemograf mataair }\end{array}$ \\
\hline $\begin{array}{l}\text { Turbulent - aliran } \\
\text { conduit }\end{array}$ & konstan/tidak & $\begin{array}{l}\text { Isotropis } \\
\text { anisotropis }\end{array}$ & Tunak/tak tunak & $\begin{array}{l}\text { Jaringan sungai } \\
\text { bawah tanah }\end{array}$ \\
\hline
\end{tabular}

Sumber: (Ford and Williams, 1992)

Informasi-informasi diatas dapat diperoleh dengan pendekatan-pendekatan seperti imbangan air dan pemboran yang biasa dilakukan pada survey airtanah akuifer non-karst. Sementara itu analisis hidrograf mataair karst dan penelusuran sistem sungai bawah tanah (water tracing) lebih dikembangkan untuk penyelidikan khusus akuifer karst. Selanjutnya, Tabel 2.3. mengelompokkan survey dan analisis hidrologi karst berdasarkan sifat dari aliran yang menonjol.

Dalam bahasan ini tidak akan didiskusikan semuanya mengenai berbagai cara analisis yang mungkin dilakukan di akuifer karst untuk mendeskripsikan sifat fisik dan terutama kondisi airtanah karst. Beberapa hal utama yang akan dibahas adalah mengenai hidrograf dan kemograf mataair karst serta tracer test untuk mengetahui sistem dan jaringan sungai bawah tanah di akuifer karst.

\section{Teknik survey dan eksplorasi}

Seperti sudah dikemukakan pada bahasan-bahasan sebelumnya, masalah utama survey airtanah di karst adalah terutama pada sistem dimana aliran conduit sudah berkembang dengan baik. Pada kondisi conduit ini, loronglorong solusional yang dominan menyebabkan sulitnya mengevaluasi kondisi batas akuifer secara tegas, mengevaluasi kondisi aliran (turbulent), serta keberadaan tipe akuifer yang bersifat heterogen-anisotropis. Sementara itu, pada akuifer karst yang belum begitu berkembang dengan tipe akuifer bebas (tidak tertekan) yang dapat memiliki beberapa sistem cekungan airtanah dan hubungan antar sungai bawah tanah yang masih mungkin dicari secara sederhana (satu sungai bawah tanah keluar pada satu mataair), maka survey sederhana yang dapat dilakukan adalah dengan membuat flownet atau peta kontur airtanah yang kemudian dapat dicari batas cekungan airtanahnya (groundwater divide) serta dengan menggunakan pelacakan metode tracing (tracer test) baik itu dengan larutan atau radioaktif. Tracer test ini akan dibahas secara khusus pada bahasan selanjutnya. Sedangkan pada akuifer tertekan, batas cekungan airtanah masih mungkin didefinisikan dengan menggunakan pemetaan kontur dan aliran airtanah, sementara tracer test sulit dilakukan karena lamanya waktu tunggu. Pada kondisi ini tracer test yang mungkin digunakan adalah dengan metode isotop (Ford and Williams, 1992).

Penggunaan teknologi Remote Sensing (RS) dengan batuan Sistem Informasi Geografis (SIG) untuk penyelidikan airtanah termasuk pada kuifer karst akan memberikan pemetaan yang efektif terhadap kenampakan di permukaan bumi yang kondusif terhadap distribusi dan potensi airtanah pada suatu wilayah (Sander, 1996). Selanjutnya dikatakan pula bahwa integrasi dari RS and SIG akan menyediakan pengetahuan yang lebih baik secara spasial mengenai sumberdaya airtanah karena kemampuan SIG 
untuk menampilannya secara spasial dan akurat dari banyak data dengan sumber berbeda. Beberapa penelitian dengan bantuan teknologi RS dan SIG diantaranya oleh Parizek (1976) dalam Ford and Williams (1992) menggunakan pendekatan kelurusan (lineament) dan retakan (fracture) untuk mendelineasi sistem sungai bawah tanah di batuan karbonat. Hasil penelitian seperti yang disajikan pada Gambar 2.15 menggunakan pendekatan pola-pola kelurusan dan perpotongannya untuk menentukan posisi mata air dan lokasi yang tepat untuk membuat sumur. Selain itu, foto udara infra merah thermal juga sering digunakan untuk menentukan lokasi keluarnya sungai bawah tanah berupa mata air di laut. Prinsip kerjanya adalah adanya perbedaan suhu yang mencolok antara suhu sungai bawah tanah dan suhu airlaut.

Selanjutnya, investigasi pada akuifer karst dapat dibantu dengan metode geofisika. Metode geofisika ini mensyaratkan adanya variasi vertikal dan horisontal dari sifat fisik perlapisan batuan di bawah permukaan bumi. Jika ada ketidak selarasan (discontinuities) sifat fisik perlapisan batuan, logikanya pasti terdapat perbedaan geologi. Metode geofisika yang paling sering digunakan untuk mengevaluasi kondisi hidrologi akuifer karst adalah metode resistivity. Metode ini mempunyai prinsip bahwa arus listrik yang dialirkan ke bawah permukaan bumi akan terpengaruh oleh nilai tahanan jenis batuan (resistivity) yang bervariasi menurut pori-pori batuan, sifat dan karakteristiknya termasuk yang ada pada akuifer karst. Ford and Williams (1992) mengatakan bahwa metode resistivity ini telah terbukti untuk dapat mendeskripsikan variasi vertikal dari akuifer karst karena metode ini dapat membedakan adanya batuan karbonat yang kompak, yang jenuh air, maupun yang tidak. Memang tidak dapat dipungkiri bahwa terkadang metode ini meleset untuk dapat secara presisi menentukan lokasi yang mengandung airtanah karst dalam jumlah yang cukup. Selanjutnya, Loke (2000) menjelaskan tentang teknik inverse imaging 2-dimensi yang mampu digunakan untuk menentukan keberadaan goa karst dan kemungkinan terdapatnya sumberdaya air didalamnya, seperti yang disajikan pada Gambar 2.16.

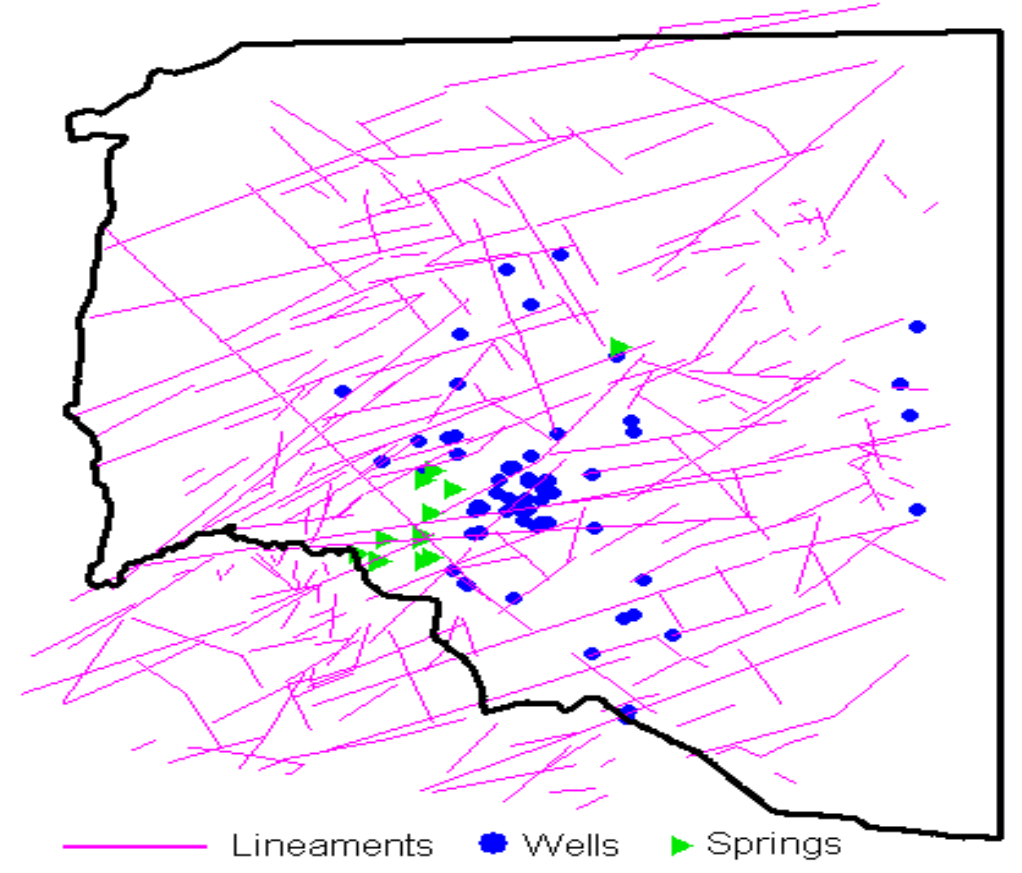

Gambar 2.15. Pendekatan retakan dan kelurusan untuk sumber air karst 


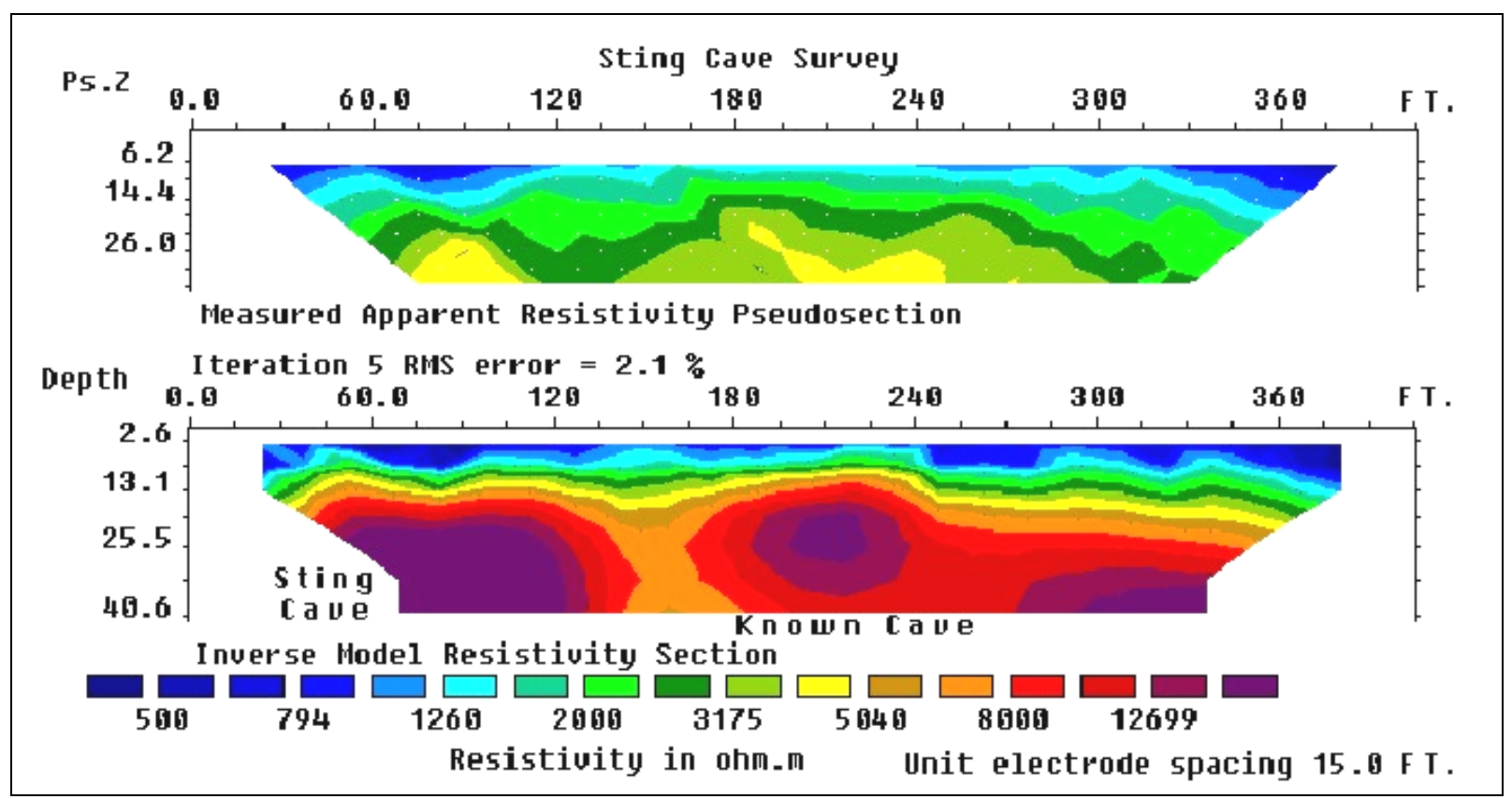

Gambar 2.16. Contoh Inversion Model 2-D untuk pendugaan airtanah di goa (Loke, 2000)

Akhir-akhir ini telah banyak metode geofisika lain yang dapat digunakan untuk mengevaluasi potensi hidrologi di akuifer karst seperti yang disajikan pada Tabel 2.4 .

Tabel 2.4. Metode geofisika yang dapat digunakan untuk survey hidrologi karst

\begin{tabular}{|l|l|}
\hline \multicolumn{1}{|c|}{$\begin{array}{c}\text { Metode } \\
\text { geofisika }\end{array}$} & \multicolumn{1}{|c|}{ Sifat fisik teramati } \\
\hline Geolistrik & Resistivity/conductivity \\
Seismic & Kecepatan gelombang \\
Method & Density (kepadatan) \\
Gravity & Sifat magnet bumi \\
Magnetic & Radioactivity \\
Radiometric & Dialectric Permittivity \\
Radar & $\begin{array}{l}\text { Tergantung sensor yang digunakan } \\
\text { (cpt;suhu;resistivity;conductivity, dll) }\end{array}$ \\
Uji lobang bor
\end{tabular}

Penggunaan analisis lobang bor selain untuk menentukan perlapisan dan sifat batuan selain dengan menggunakan sensor seperti yang disajikan pada Tabel 2.4. juga dapat diamati tanpa sensor secara langsung untuk memperoleh data- data, diantaranya lokasi/kedalaman dimana sutau akuifer karst mempunyai nilai permeabilitas yang tinggi serta koefisien simpanan dari akuifer karst yanr terukur. Selain itu, borehole recharge test atau uji lobang bor dengan memasok air ke dalam lobang dapat digunakan untuk menentukan nilai permeabilitas $(K)$ dari suatu segmen tertentu dari akuifer karst. Sementara itu, uji pompa lobang bor (pumping test) juga dapat dilakukan di akuifer karst walaupun mempunyai keterbatasanketerbatasan tertentu.

\section{Teknik Pelacakan Airtanah Karst (Water Tracing)}

Teknik water tracing dikenal secara luas sebagai salah satu metode yang dapat dipertanggungjawabkan untuk mencari hubungan antar goa atau sistem sungai bawah tanah di akuifer karst. Hal ini dilakukan oleh MacDonalds and Partners (1983) untuk melacak sistem sungai bawah tanah di karst Gunung Sewu, Yogyakarta. Hasil pelacakan tersebut sampai sekarang masing digunakan oleh pihak-pihak yang berkepentingan 
terhadap pengembangan sumberdaya air karst di wilayah tersebut. Teknik ini secara sederhana adalah memasukkan atau menuang sesuatu pada aliran air di swallow hole atau sungai yang akan masuk ke goa, atau ponor/sinkhole dan kemudian menghadang atau menjemput pada suatu lokasi yang diperkirakan mempunyai hubungan dengan titik awal kita menuang tracer tadi. Jika tracer yang kita tuang "tertangkap" secara fisik ataupun dengan alat pengukur yang lain maka dapat dipastikan bahwa ada hubungan antara titik pertama tempat kita menuang tracer dengan titik kedua tempat kita mencegat tracer tersebut.

Jankowski (2001) membagi bahan pelacakan menjadi tiga yaitu tracers, kimia \& pewarna (dye), serta radioaktiv. Prinsip ketiga jenis bahan pelacakan ini dalah sama yaitu memasukkan bahan pelacak pada sebagaian sistem aliranyang diperkirakan pada akuifer karst dan melakukan monitoring pada titik output atau keluaran dari sistem tersebut. Karena sifat aliran di akuifer karst yang cepat, terutama pada conduit serta adanya kemungkinan kebocoran atau rumitnya jaringan sistem karst bawah tanah, maka untuk identifikasi daerah tangkapan dan keluaran pada sistem akuifer karst, tracer haruslah mempunyai syarat-syarat seperti berikut ini :

- Tidak beracun

- Larut di air

- Dapat dilakukan dengan jumlah yang tidak terlalu banyak

- Resisten (tidak merubah reaksi kimia di air)

- Tidak dapat terserap oleh batuan

- Tidak terpengaruh reaksi pertukaran ion

- Murah

- Mudah dianalisis

Selanjutnya beberapa contoh tracer akan dibahas satu persatu :

\section{a. Garam}

Garam sebagai $\mathrm{NaCl}$ (natrium klorida) atau $\mathrm{KCl}$ (kalium klorida) merupakan bahan pelacak yang pertama kali dan paling sering digunakan pada teknik ini. Selanjutnya $\mathrm{LiCl}$ (lithium klorida) juga digunakan dengan tingkat keberhasilan yang cukup tinggi. Karena sifatnya yang sangat mudah larut dalam air, penggunaan garam untuk media tracing test ini memerlukan jumlah garam yang sangat banyak, terutama untuk mendeteksi jaringan sungai bawah tanah yang berjarak panjang dan debit yang besar. Jika jumlah garam yang dimasukkan ke air kurang, maka pada titik output yang diamati tidak akan terdeteksi adanya korelasi, walaupun sesungguhnya merupakan satu sistem dengan titik inputnya. Bogli (1980) mencontohkan bahwa untuk jarak tracing sekitar $3 \mathrm{~s} . \mathrm{d} 5 \mathrm{~km}$ dibutuhkan setidaknya $500 \mathrm{~kg}$ garam untuk mencapai hasil yang optimal. Selanjutnya dikemukakan pula bahwa penggunaan garam terbanyak yang pernah dilakukan adalah pelacakan sistem sungai bawah tanah di Tuttlingen, Jerman ketika 50.000 $\mathrm{kg}$ garam dimasukkan untuk mencari hubungan antara sebuah ponor dan mata air karst terbesar di Jerman, Aaschquelle. Setelah durasi waktu 4 hari, konsentrasi terbesar garam di mataair tersebut teramati dengan konsentrasi $\mathrm{Cl}$ yang hanya mencapai $39 \mathrm{mg} / \mathrm{l}$. Hal ini membuktikan bahwa adanya daya larut yang tinggi dari garam serta kondisi lorong selama transport membuktikan besarnya keterbatasan metode tracing dengan garam.

\section{b.Spora}

Bahan tracer yang sering digunakan dapat bermacam-macam, tetapi hanya beberapa saja yang sukses dilakukan seperti penggunaan spora dari "lycopodium clavatum" (Bogli, 1980). Spora ini mempunyai diameter 25 mikron, termasuk serbuk sarinya yang mempunyai kerapatan partikel sedikit lebih diatas air sehingga jika kondisi aliran lorong-lorong solusional adalah turbulen, spora ini tetap akan bertahan dalam air dan mudah dideteksi pada titik output yang dikehendaki. Keuntungan dari penggunaan spora ini adalah karena sifatnya yang tidak beracun (non-toxic), dan banyak terdapat di air dimanapun di bumi ini. Biasanya, tracing dilakukan dengan memberi warna pada beberapa spora tersebut dengan warna yang berbeda-beda, sehingga beberapa input point dapat diuji secara besamasama. Bogli juga mengungkapkan bahwa cara ini terbukti berhasil untuk menentukan jaringan antara sungai permukaan yang masuk ke karst dengan mataair. Sementara itu jumlah spora yang hilang saat waktu transport cukup banyak dan 
kemungkinan karena terserap oleh sedimen di sungai bawah tanah.

\section{c. Pewarna (dye) dan tracer kimia}

Metode pewarna ini terkesan sederhana karena hanya memberi laritan pewarna pada air sehingga dapat diamati atau ditangkap dengan sensor pada output yang diinginkan. Pada kondisi yang memungkinkan, dye dikombinasi dengan zat kimia yang biasa digunakan adalah pewarna berfluorescence atau uranin yang terbukti efektif sampai jarak $25 \mathrm{~km}$ (Bogli, 1980). Sensor pengamat yang biasa digunakan adalah fluorometer atau spektrofotometer baik itu di lapangan atau dilaboratorium. Contoh hasil pelacakan dengan metode ini disajikan pada Gambar 2.17.

\section{Dye Traces Map Water Flow Routes to Springs}

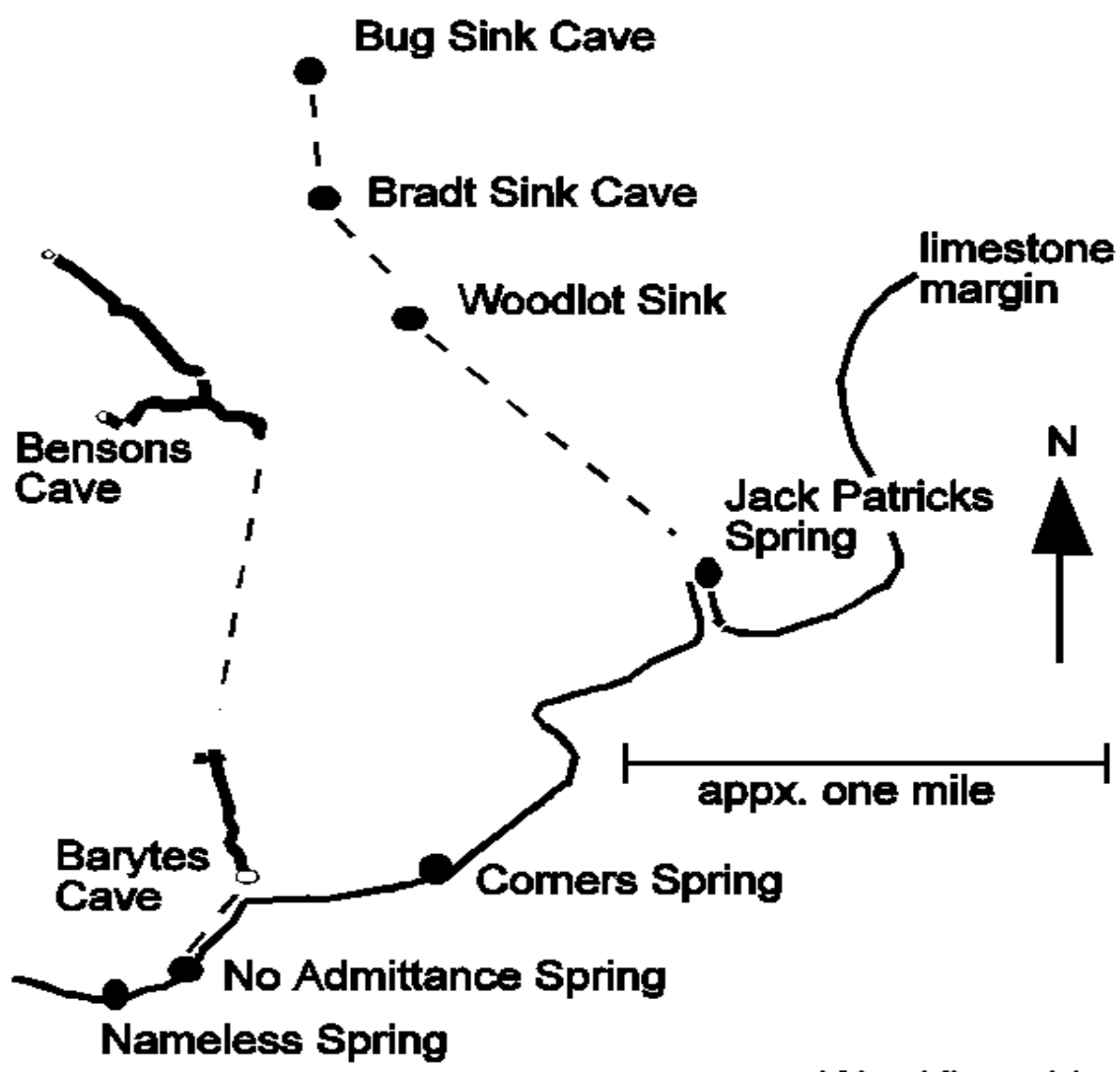

W. v.Kiparski

Sumber : http://www.galaxy.net/ trbarton/cavenews/picture/jack3.gif

Gambar 2.17. Hasil dari metode pewarna untuk tracing 


\section{d. Radioaktif}

Penggunaan radioaktif untuk tracing di airtanah karst baru dimulai sekitar tahun 1990-an. Metode dengan radioaktif ini secara prinsip dapat dibagi menjadi dua yaitu (a) radioaktif yang ditambahkan ke dalam airtanah karst dan (b) menganalisis radioaktif yang sudah ada secara alami di airtanah karst. Secara teori, tritium yang merupakan isotop dari hidrogen merupakan radioaktif alami yang paling baik digunakan sebagai tracer karena selalu ada di air dan relatif tidak mudah diserap selama air bergerak (Bogli, 1980). Kesulitannya hanyalah pada pendeteksian tritium karena isotop ini mengeluarkan energi yang sangat kecil dan tidak mungkin dideteksi dengan alat apapun di lapangan. Untuk melakukan analisis, sampel air perlu diambil dan dibawa ke laboratorium. Meskipun demikian, penggunaan tritium yang memiliki waktu paruh 12,26 tahun sebagai tracer ini telah terbukti berhasil selama ini, terutama jika kondisi hidrogeokimia airtanah karst didominasi oleh proses adsorbsi dan pertukaran kation (Jankowski, 2001). Tracer radioaktif lain yang juga dapat digunakan diantaranya adalah Bromine-82 (waktu paruh= 36 jam). Sayangnya, penggunaan Bromine-82 ini tidak begitu direkomendasikan karena adanya efek kimia pada airtanah karst. Tracer radioaktif lain yang dapat digunakan diantaranya adalah lodine-131 (waktu paruh 8 hari), Chromium-51 (28 hari), dan Cobalt-58 (71 hari). Tiga tracer yang disebutkan belakangan ini mempunyai kelemahankelemahan tertentu terhadap kondisi lapangan.

\section{e. Tracer yang lain}

Beberapa bahan pelacak yang dapat digunakan diantaranya adalah busa plastik (alkylbenzene-sulphonate) yang terbukti berhasil baik pada kondisi tertentu, kemudian kalium permanganat yang berwarna merah (ada efek terhadap kimia airtanah karst), arang teraktivasi (harga mahal), serta germs dengan spesies tertentu seperti seratia marcenses. Tracer yang disebutkan ini tidak terlalu sering digunakan dan kadang mempunyai kegagalan dalam hal aplikasinya.

\section{ANALISIS MATAAIR KARST (CAVE SPRINGS)}

Sebelum membahas mengenai cara analisis mataair karst, ada baiknya kita sepakati terlebih dahulu definisi dan karakteristik mataair di daerah karst. Secara umum, mataair adalah pemunculan airtanah ke permukaan bumi karena suatu sebab. Sebab munculnya mataair dapat berupa topografi, gravitasi, struktur geologi, dll. Sementara itu, mata air karst menurut White (1988) adalah air yang keluar dari akuifer karst terutama pada cavities hasil pelarutan di permukaan atau bawah permukaan bumi.

Beberapa keunikan yang dijumpai pada mataair karst adalah mataair dengan debit yang sama besar, bersuhu sama, mempunyai kesadahan yang sama dapat pula dijumpai pada mataair karst di tempat lain. Selain itu, debit mataair karst biasanya mempunyai debit yang besar, dan di negara ${ }^{2}$ Eropa disebut-sebut mampu menggerakkan kincir angin di daerah pertanian, walaupun tidak sedikit mataair karst yang mempunyai debit aliran kecil. Keunikan yang lain adalah karakteristik mataair karst yang sangat tergantung dari tingkat karstifikasi suatu wilayah. Elevasi suatu mataair karst dapat semakin dalam menurut waktu dan bila mencapai local base level, maka mata air disekitarnya yang lebih kecil akan hilang dan bergabung sesuai dengan melebarnya lorong conduit. Dengan kata lain semakin sedikit jumlah mataair karst, maka semakin besar pula debit yang keluar. Selanjutnya, klasifikasi mataair karst hampir tidak berbeda dengan klasifikasi mataair pada kawasan lain di permukaan bumi :

\section{- Klasifikasi atas dasar periode pengalirannya}

a. Perennial springs : mataair karst yang mempunyai debit yang konsisten sepanjang tahun

b. Periodic springs : mataair karst yang mengalir pada saat ada hujan saja

c. Intermitten springs : mataair karst yang mengalir pada waktu musim hujan

d. Episodically flowing springs : mataair karst yang mengalir pada saat-saat tertentu saja dan tidak berhubungan dengan musim atau hujan 
- Klasifikasi atas dasar struktur geologi (Gambar 2.18)

a. Bedding springs, contact springs : mataair karst yang muncul pada bidang perselingan formasi batuan atau perubahan jenis batuan, misal jika akuifer gamping terletak diatas formasi breksi vulkanik

b. Fracture springs : mataair karst yang keluar dari bukaan suatu joint atau kekar atau retakan di batuan karbonat

c. Descending springs : matair karst yang keluar jika ada lorong conduit dengan arah aliran menuju ke bawah

d. Acending springs : matair karst yang keluar jika ada lorong conduit dengan arah aliran menuju ke atas. Jika debitnya besar sering disebut sebagai vauclusian spring (Gambar 2.19)

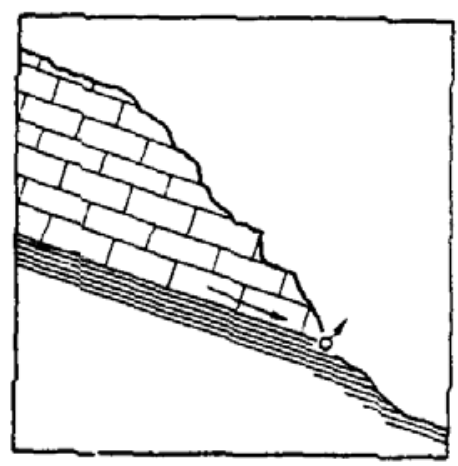

Mataair kontak

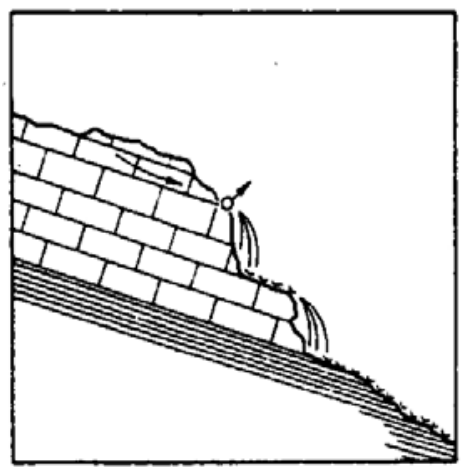

Mataair perlapisan
- Klasifikasi atas dasar asal airtanah karst

a. Emergence springs : mataair karst yang mempunyai debit besar tetapi tidak cukup bukti mengenai daerah tangkapannya

b. Resurgence springs : mataair karst yang berasal dari sungai yang masuk kedalam tanah dan muncul lagi di permukaan

c. Exsurgence springs : mataair karst dengan debit kecil dan lebih berupa rembesan-rembesan (seepages)

Selain klasifikasi mataair karst yang disebutkan diatas, masih terdapat beberapa jenis mataair karst yaitu mataair karst yang muncul di bawah permukaan laut (submarine karst springs) yang disajikan pada Gambar 2.19, dan mataair di goa (cave springs).

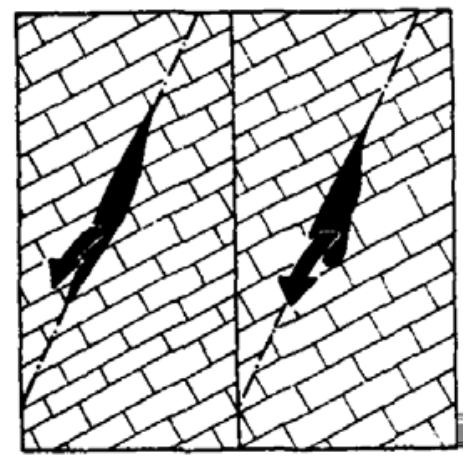

Mataair kekar

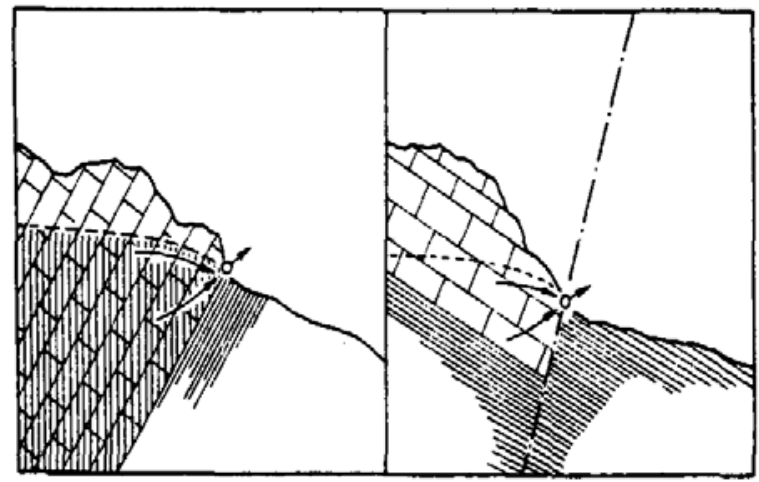

Mataair overflow

Gambar 2.18. Jenis-jenis mataair karst karena struktur geologi (White, 1988) 


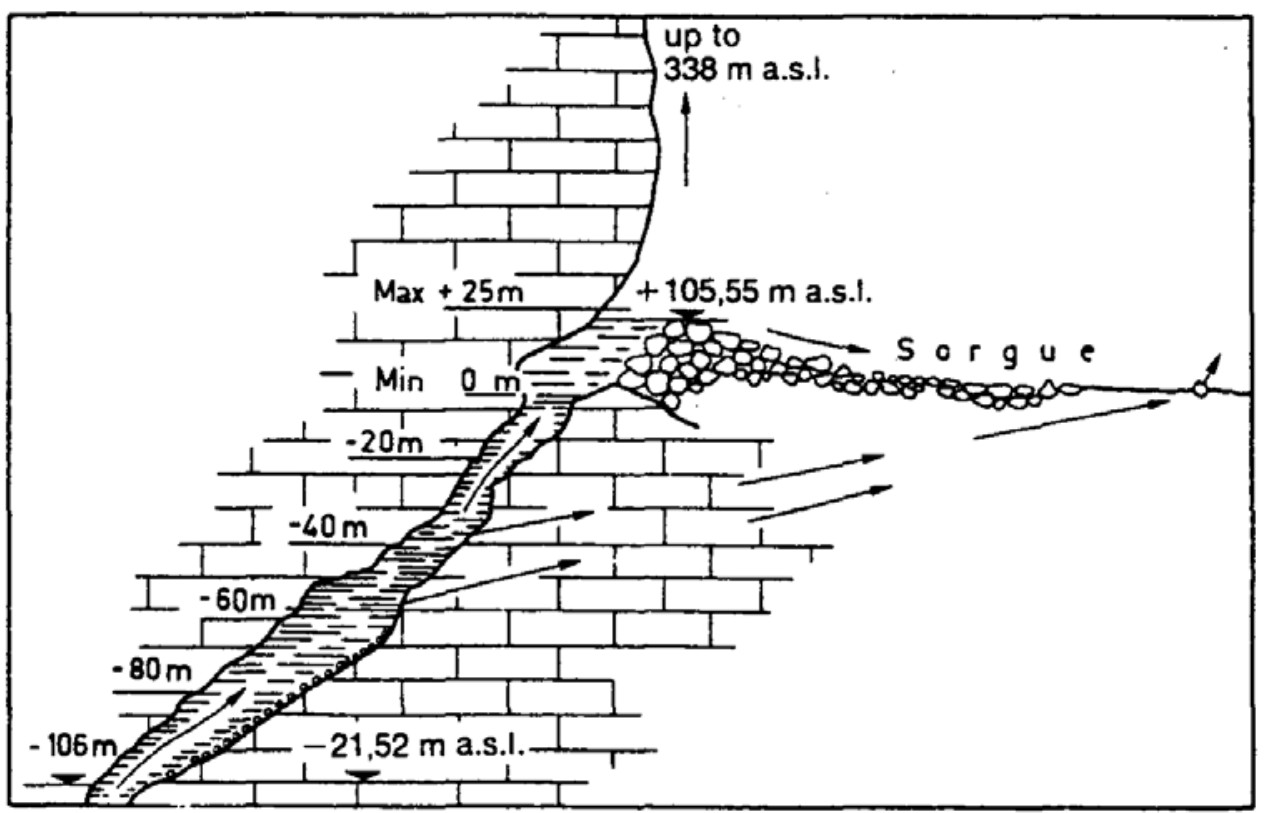

Vaucluse spring

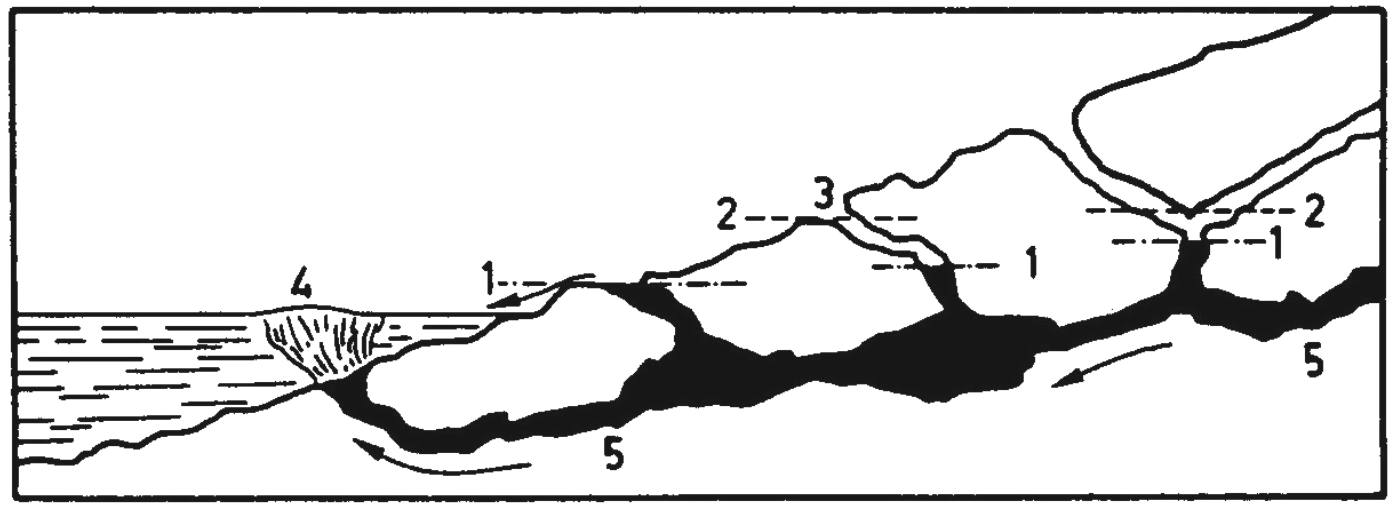

Submarine spring

Gambar 2.19. Vaucluse dan submarine springs (White, 1988) 


\section{Hidrograf mataair karst}

Dalam ilmu hidrologi, hidrograf dikenal sebagai gambar atau grafik yang menggambarkan hubungan antara waktu dengan tinggi muka air sungai, debit aliran, atau debit sedimen (Adji dan Suyono, 2004). Hidrograf ini biasanya diaplikasikan pada analisis hidrologi untuk sungai permukaan. Hidrograf aliran ini sangat penting untuk analisis hidrologi seperti menghitung jumlah air di sungai, jumlah sedimen yang terangkut, analisis respon hujan dan aliran serta daerah aliran sungai (DAS), dll. Contoh hidrograf beserta bagian-bagiannya disajikan pada Gambar 2.20.

Gambar 2.20 menunjukkan hidrograf banjir dan hujan penyebabnya. Atas dasar bentuk hidrograf banjir, bagian-bagian hidrograf banjir terdiri dari

1. lengkung naik (rising $\operatorname{limb}$ )

2. puncak (crest or peak)

3. lengkung turun (falling limb or recession curve)

Faktor-faktor yang secara umum mempengaruhi hidrograf aliran adalah :

1. bagian lengkung naik sampai puncak dipengaruh oleh karakteristk hujan (jumlah, intensitas, penyebaran) dan hujan sebelumnya.

2. bagian turun, dipengaruhi oleh pelepasan air dari simpanan air di DAS, simpanan air dalam alur sungai, simpanan lengas tanah dan simpanan airtanah.

Pasangan data hujan dalam bentuk hietograf dan data aliran dalam bentuk hidrograf banjir sangat berguna untuk analisis hubungan hujan dengan tinggi aliran banjir. Parameter hidrologinya adalah :

1. puncak banjir $(\mathrm{Qp})$

2. waktu konsentrasi (Time of concentration or time lag) $=\mathrm{Tc}$

3. waktu mencapai puncak (time to peak) $=$ Tp

4. waktu dasar (time base) $=\mathrm{Tb}$

5. jumlah hujan

6. intensitas hujan

7. koefisien aliran
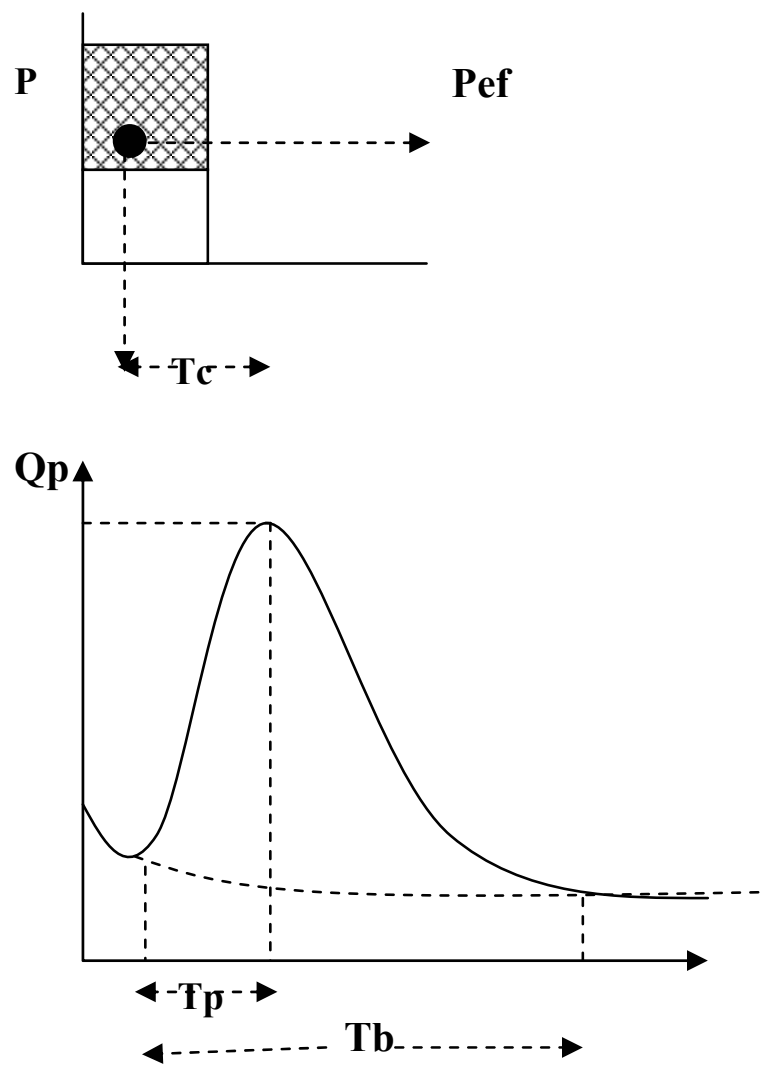

Gambar 2.20. Bagian-bagian dari hidrograf banjir (Adji dan Suyono, 2004)

Di akuifer karst, hidrograf aliran biasanya diaplikasikan untuk menganalisis karakteristik mata air atau sungai bawah tanah karst. Karakteristik aliran sungai bawah tanah karst yang unik adalah respon yang cepat terhadap variasi external misalnya hujan, suhu, bahkan tanah dan aktivitas tumbuhan (White, 1993). Akibatnya, analisis mengenai respon tersebut dapat digunakan untuk mengkarakteristik struktur internal dari akuifer karst. Bahkan, dari bentuk hidrograf mataair karst dapat diketahui sistem aliran yang dominan apakah itu conduit atupun diffuse. Gambar 2.21 menunjukkan contoh dari hidrograf mataair karst pada satu kali kejadian hujan. Pada Gambar 2.21 tersebut, diagram 
batang menunjukkan adanya kejadian hujan yang menyebabkan terjadinya lengkung naik.

Satu hal yang perlu diperhatikan dari Gambar 2.21 adalah bahwa adanya hujan akan menaikkan debit mataair pada sistem karst secara cepat. Walupun terdapat jeda waktu (time lag), tetapi tidak terlalu lama dan hidrograf segera naik pada beberapa saat setelah kejadian tetapi masih terjadi hujan. Waktu jeda tersebut bukanlah merupakan persyaratan waktu dari air hujan untuk mengalir dari masukan/inlet menuju ke mataair karst, tetapi hanyalah waktu sesaat untuk dapat menaikkan hidrograf. Selanjutnya, kenaikan tinggi muka air di bagian atas (upstream) akuifer karst merupakan pasokan penting bagi airtanah karst untuk menaikkan hydraulic head yang menyebabkan debit mataair bertambah. Akibatnya, debit mataair meningkat dan menjadi jauh lebih tinggi dari keadaan biasanya (debit dari aliran dasar) dan akhirnya mencapai puncak (crest) yang mempunyai debit sama tinggi dengan debit puncak aliran permukaan pada input $\left(\mathbf{Q}_{\max }\right)$. Sesudahnya, aliran dari mataair akan turun dengan karakteristik yang jauh lebih pelan daripada pada saat hidrograf naik. Pada kondisi yang ideal, penurunan ini akan perlahan-lahan menuju saat debit mataair karst hanya berasal dari aliran dasar (base flow) saja.

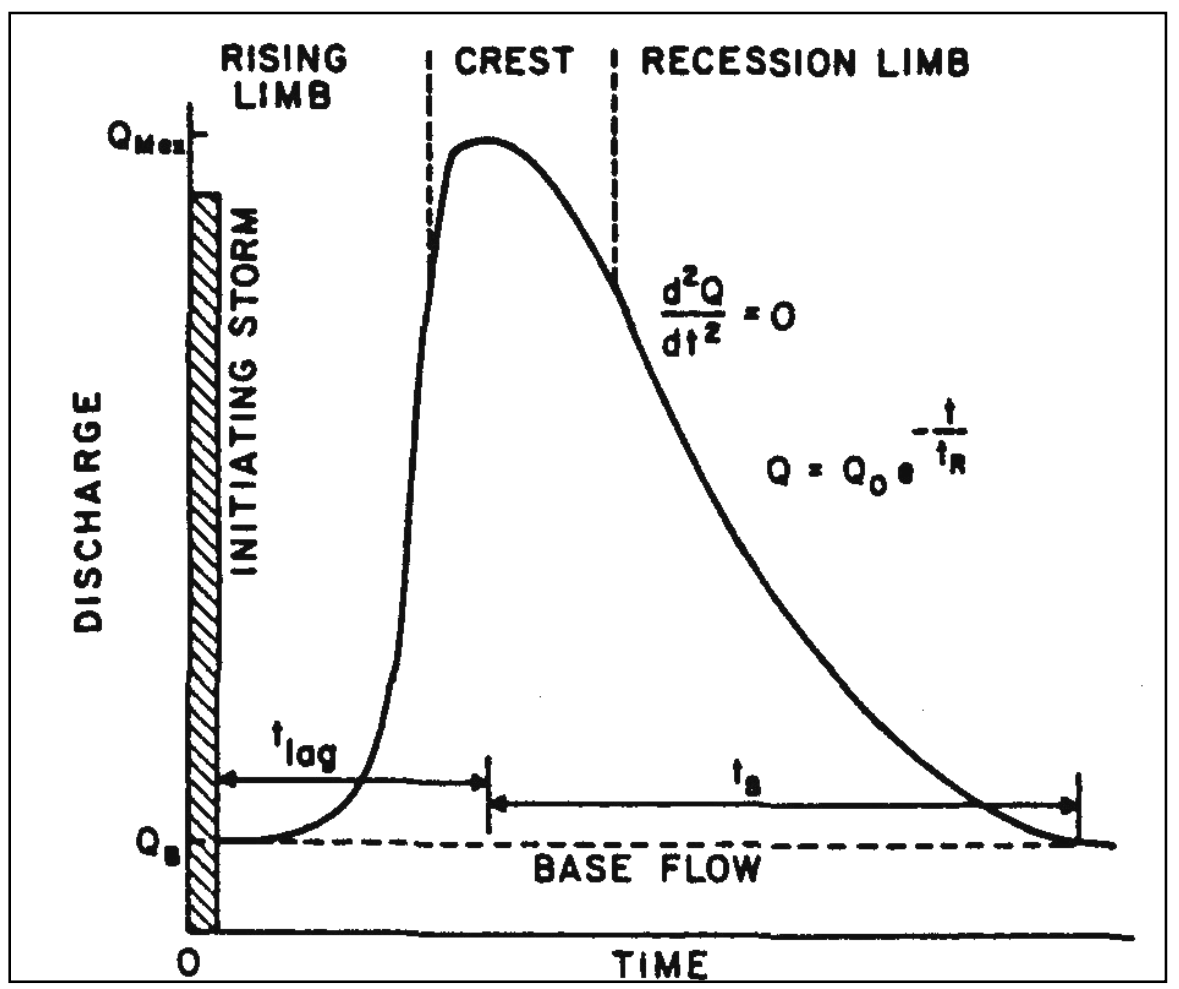

Gambar 2.21. Hidrograf mata air karst pada satu kali kejadian hujan (White, 1993) 


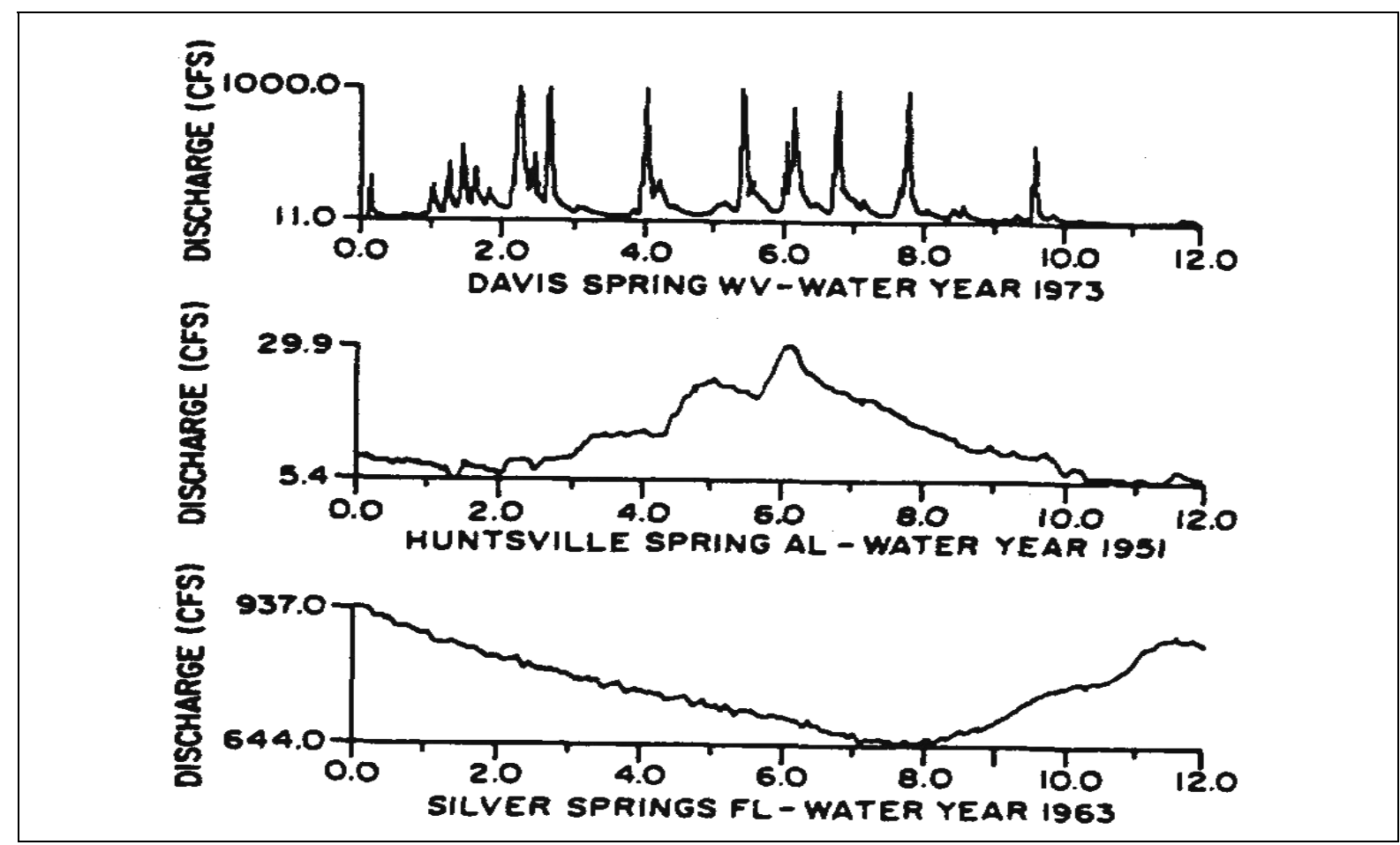

Gambar 2.22. Hidrograf respon hujan pada mataaair karst (White, 1993)

Selanjutnya, pada suatu sistem akuifer karst yang didominasi oleh imbuhan allogenic dan proses karstifikasinya sudah sangat baik yang dicirikan dengan lorong conduit, maka akan memiliki respon yang sangat cepat terhadap hujan. Sebaliknya, jika akuifer karst yang didominasi oleh sistem diffuse, sedikit conduit, dan sedikit imbuhan allogenic, maka bentuk hidrografnya akan sangat berbeda. Gambar 2.22 menunjukkan perbedaan 3 hidrograf akuifer di daerah karst yang mempunyai respon yang berbeda-beda.

Hidrograf mataair karst di Davis Spring (paling atas) menunjukkan bahwa waktu respon hujan terhadap debit puncak sangat pendek. Dapat dikatakan bahwa setiap kejadian hujan akan langsung memberikan kontribusi yang cepat untuk menjadi puncak hidrograf seperti yang biasa terjadi pada hidrograf sungai permukaan. Sementara itu, Huntsvillee Spring (tengah) menunjukkan bahwa waktu respon kejadian hujan terhadap kenaikan debit sebanding dengan waktu antar kejadian hujan sehingga puncak hidrograf tidak terjadi secara tiba-tiba. Hidrograf di Silver Spring (bawah) bahkan menunjukkan waktu respon yang jauh lebih lama dari waktu antar kejadian hujan, sehingga hidrograf mataair terlihat datar dan puncak hidrograf mungkin hanya berkorelasi dengan variasi musim tahunan saja.

Pada akuifer yang mempunyai respon hujan terhadap hidrograf sangat cepat, maka dapat dikuantitatifkan bahwa (lihat Gambar 2.21) bahwa rasio antara debit puncak dan aliran dasar adalah $\mathbf{Q}_{\max } / \mathbf{Q}_{\mathbf{B}}$, yang dapat kita sebut sebagai "kecepatan respon" di akuifer karst. Kecepatan respon tersebut dapat dikatakan merupakan fungsi dari intensitas hujan dan tingkat pekembangan lorong conduit pada akuifer karst. Selanjutnya, White (1993) membuat tiga kategori kecepatan respon akuifer karst seperti yang disajikan pada Tabel 2.5 . 
Tabel 2.5. Tingkat kecepatan respon akuifer karst $\left(\mathbf{Q}_{\max } / \mathbf{Q}_{\mathbf{B}}\right)$ pada cekungan kecil

\begin{tabular}{|l|l|}
\hline \multicolumn{1}{|c|}{ Tingkat } & \multicolumn{1}{c|}{$\mathbf{Q}_{\max } / \mathbf{Q}_{\mathbf{B}}$} \\
\hline Sangat cepat & 100 \\
\hline Sedang & 10 \\
\hline Sangat lambat & $1-3$ \\
\hline
\end{tabular}

\section{Analisis kemograf mataair karst}

Kemograf adalah suatu grafik atau diagram yang berisi hubungan antara komposisi kimia airtanah karst dengan waktu dan dapat bersifat musiman, tahunan, ataupun per kejadian hujan. Hujan biasanya masuk ke akuifer karst dan secara hidrokimia masih bersifat tidak jenuh (undersaturated) terhadap batuan karbonat, sehingga masih dapat dikatakan agresif untuk melarutkan batuan karbonat. Selanjutnya, di akuifer, air dari hujan tersebut akan bereaksi terhadap batuan karbonat dan lama kelamaan akan meningkatkan nilai indek kejenuhan (saturation index $=S I$ ) dan menurunkan daya larut terhadap batuan karbonat, dan kemudianmenjadi jenuh dan mengendap membentuk padatan (solid). Waktu untuk mencapai titik kesetimbangan $(\mathrm{SI}=0=$ jenuh) adalah sekitar 10 hari dan dapat dibandingkan dengan lamanya air hujan bergerak dari input ke mataair karst (White, 1993).

Secara teoritis, air yang tersimpan pada retakan dapat dikatakan sudah jenuh, sementara air yang mengalir pada lorong conduit masih belum jenuh. Akibatnya, komposisi kimia airtanah yang diamati pada mataair karst dapat berfluktuasi tergantung dari variasi debitnya, variasi kejadian hujan, dan mungkin juga terhadap aktivitas lain di daerah tangkapan hujannya (catchment area). Selanjutnya, analisis variasi komposisi kimia melalui kemograf akan sangat menarik untuk mengetahui hubungannya terhadap variasi musim, kejadian hujan, debit atau banjir. Gambar 2.23 menunjukkan variasi nilai $\mathrm{Ca}^{2+}$, $\mathrm{Mg}^{2+}$, dan $\mathrm{HCO}_{3}{ }^{-}$terhadap debit dan hujan.

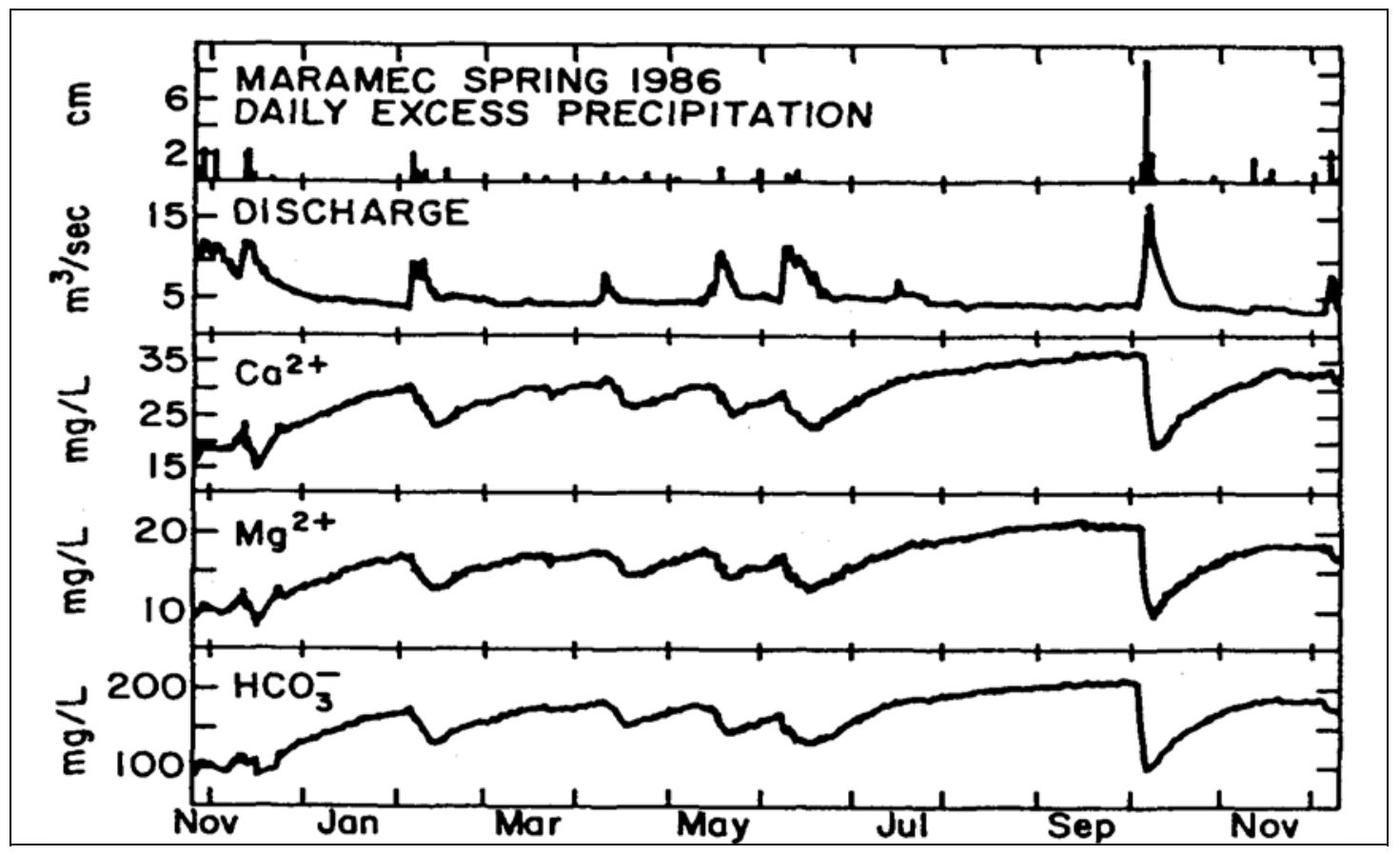

Gambar 2.23. Hujan, debit dan kemograf pada mataair karst (White, 1993) 


\section{DAFTAR PUSTAKA}

Acworth, R.I.,2001a. Electrical Methods in Groundwater Studies, Short Course Note, School of Civil and Environmental Engineering, University of New South Wales, Sydney, Australia

Adji, T.N., Haryono, E., Suprojo. S.W., 1999. Kawasan Karst dan Prospek Pengembangannya di Indonesia, Prosiding Seminar PIT IGI di Universitas Indonesia, 26-27 Oktober 1999

Adji, T.N., Suyono, 2004, Bahan Ajar Hidrologi Dasar, Fakultas Geografi UGM (tidak dipublikasikan)

Bogli, 1980. Karst Hydrology and Physical Speleology. Springler-Verlag

Domenico,P.A. and Schwartz, F.W., 1990, Physical and Chemical Hydrogeology. $2^{\text {nd }}$ Ed. John Wiley \& Sons

Fetter, C.W., 1994, Applied Hydrogeology. $3^{\text {rd }}$ Ed. Macmillan Publishing Company, New York

Ford, D. and Williams, P. 1992. Karst Geomorphology and Hydrology, Chapman and Hall, London

Jankowski, J., 2001. Hydrogeochemistry, Short Course Note, School of Geology, University Of New South Wales, Sydney, Australia (tidak dipublikasikan)

Linsley, R.K., Kohler, M.A., Paulhus, J.L., 1975. Hydrology for Engineers. $2^{\text {nd }}$. Ed. Mc Graw Hill Kogakusha Ltd. Tokyo, Japan.

Loke, H.M., 2000, Electrical Imaging Surveys for Environmental and Engineering Studies, A Practical Guide to 2-D and 3-D Surveys, http://www.abem.se , email : mhloke.pc.jaring.my

MacDonalds and Partners. 1984. Greater Yogyakarta - Groundwater Resources Study. Vol 1: Main Report. Yogyakarta, Directorate General of Water Resources Development Project (P2AT)

Sander, P.1996. Groundwater Assessment Using Remote Sensing and GIS in A Rural Groundwater Project In Ghana : Lesson
Learned. Hydrogeology Journal, Volume 4, no.3, 1996

Sweeting, M.M., 1972, Karst Landforms, Macmillan, London.

Todd, D.K., 1980. Groundwater Hydrology. $2^{\text {nd }}$ Ed. John Wiley \& Sons

Trudgil, S., 1985, Limestone Geomorphology, Longman, New York.

White, W.B., 1988. Geomorphology and Hydrology of Karst Terrain. Oxford University Press, New York

White, W.B., 1993. Analysis of Karst Aquifer. In:Alley, W.M. (editor), regional groundwater Quality. Van Nostrand Reinhold, New York

Internet :

www.ecn.purdue/edu/.../gishyd.html

http://www.eccentrix.com/members/hydrogeologie/hidro geol/karst.gif

http://www.bae.uky.edu/sworkman/AEN438G/aquifer/aq uifer.html)

http://www.water.usgs.gov/.../jbm_exchangematrix.htm)

http://www.galaxy.net/ trbarton/cavenews/picture/jack3. gif 